\title{
Comparison of benthic foraminiferal and macrofaunal responses to organic pollution in the Firth of Clyde (Scotland)
}

\author{
M. Mojtahid ${ }^{\mathrm{a}, \mathrm{b}, *}$, F. Jorissen ${ }^{\mathrm{a}, \mathrm{b}}$, T.H. Pearson ${ }^{\mathrm{c}}$

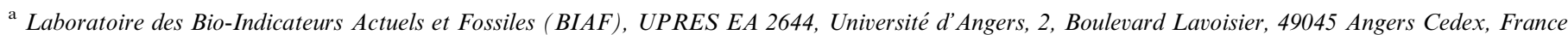 \\ ${ }^{\mathrm{b}}$ Laboratoire d'Etude des Bio-Indicateurs Marins (LEBIM). Ker Chalon, 85350 Ile D'Yeu, France \\ ${ }^{c}$ Akvplan-niva as, Polar Environment Centre, 9296 Tromso, Norway
}

\begin{abstract}
By comparing benthic foraminiferal and macrofaunal responses to sewage sludge disposal in the Firth of Clyde (Scotland), we wanted to investigate the possibility of using foraminifera as bio-indicators of marine environmental degradation. Both groups present a similar distributional pattern, with poor faunas composed of species tolerant to strong oxygen depletion near to the disposal site, surrounded by high density of opportunistic species. Farther away, faunal density decreases and equilibrium taxa gradually replace opportunistic species. No more environmental impact is perceptible beyond $3 \mathrm{~km}$. Nevertheless, some differences exist: foraminifera appear to be more impacted at the disposal site, probably as a consequence of the low $\mathrm{pH}$, a supplementary stress factor for organisms provided with a calcareous test. At $3 \mathrm{~km}$ west of the disposal site, macrofauna is comparable to the reference station, whereas foraminifera still indicate environmental degradation, suggesting their higher sensitivity to this type of pollution. It appears that benthic foraminifera may add valuable information to open marine environmental monitoring.
\end{abstract}

(C) 2007 Elsevier Ltd. All rights reserved.

Keywords: Benthic foraminifera; Macrofauna; Eutrophication; Bio-indicator; Opportunistic taxa; Firth of Clyde

\section{Introduction}

Since 1974 , up to $1.5 \times 10^{6}$ tonnes of sewage sludge have been discharged annually in an area some $8 \mathrm{~km}$ south of Garroch Head in the Arran/Ayrshire Basin (Firth of Clyde; Scotland; Fig. 1). This activity ceased in 1998 (Webster and Campbell, 2002). In June 1988, benthic macrofaunal and foraminiferal assemblages were sampled at nine stations along two perpendicular sample transects centred around the disposal site. This study makes part of an environmental survey, based on macrofaunal analyses, carried

\footnotetext{
${ }^{*}$ Corresponding author. Address: Laboratoire des Bio-Indicateurs Actuels et Fossiles (BIAF), UPRES EA 2644, Université d'Angers, 2, Boulevard Lavoisier, 49045 Angers Cedex, France. Tel.: +33 241735002; fax: +33241735352 .

E-mail addresses: meryem.mojtahid@etud.univ-angers.fr (M. Mojtahid), frans.jorissen@univ-angers.fr (F. Jorissen), thpearson@fsmail.net (T.H. Pearson).
}

out annually since 1979 . This is the first time that the impact of sewage sludge on foraminiferal faunas has been studied at this site.

Essentially, disposal of sewage sludge at sea may create two types of environmental problems: (a) localised organic enrichment causing higher sedimentary oxygen consumption, often leading to hypoxic and ultimately anoxic conditions at the sea floor (Fenchel and Finlay, 1995) and (b) the potential toxicity or pathogenicity of the deposited material (Pearson, 1986). In hydrodynamically active open marine areas, organic enrichment is unlikely to cause more than temporary nuisance problems; nutrient and carbon inputs tend to be rapidly incorporated into the marine food web, which is well adapted to metabolize large quantities of organic carbon (DoE/WTD, 1984). In enclosed, shallow, or hydrodynamically less active systems, on the contrary, severe but localised problems may be created (Pearson, 1985). The realisation of this dichotomy has led to the present opinion, that dumping at sea should preferably take 

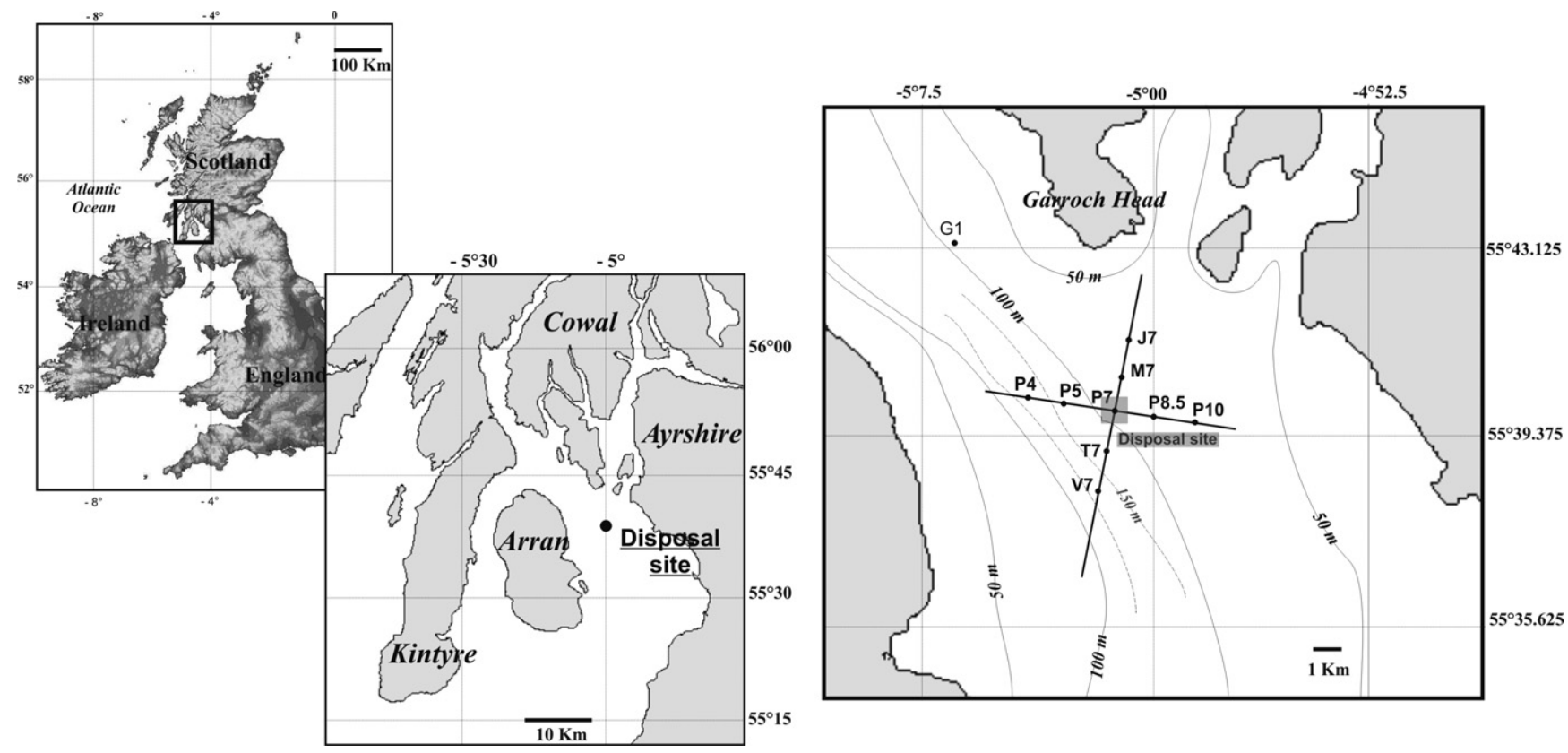

Fig. 1. Study area and sampling location (50 m and $100 \mathrm{~m}$ bathymetric curves are represented according to Matthews et al. (1999), whereas the $150 \mathrm{~m}$ bathymetric curve is tentatively indicated in function of our own depth measurements).

place in dispersive (hydrodynamically active) areas. At present sewage disposal by dumping at sea is prohibited in the EU.

The impact of sewage disposals on benthic macrofauna is well-documented (Mackay et al., 1972; McIntyre, 1977; Pearson and Rosenberg, 1978; Pearson et al., 1983, 1986; Pearson, 1986; Hellawell, 1986; Abel, 1989; Mason, 1991; Rosenberg and Resh, 1993 in Yong Cao et al., 1997) and has been measured using a variety of indicators, including biomass, species richness, and species density and composition. Foraminifera are among the most abundant protists in marine benthic environments (Murray, 1991). Because of their short life cycles, high biodiversity and the specific ecological requirements of individual species, foraminifera react quickly to environmental disturbance, and can be successfully applied as bio-indicators of environmental changes, such as those brought about by anthropogenic pollution (as defined by Kramer and Botterweg, 1991). Foraminiferal assemblages are easy to collect; they are commonly abundant, and provide a highly reliable database for statistical analysis, even when only small sample volumes are available. Furthermore, many foraminiferal taxa secrete a carbonate shell, and leave an excellent fossil record, that may be used to characterise baseline conditions, or to reconstruct the state of the ecosystem prior to the impact of pollution (Alve, 1995b). Studies of the effects of pollution on benthic foraminiferal assemblages, and their possible use as pollution indicators were initiated in the early 1960's by Resig (1960) and Watkins (1961). More recently, foraminifera have been increasingly used to monitor pollution in a wide range of marine environments, such as intertidal mudflats impacted by oil spillages (Morvan et al., 2004, 2006), tropical east Atlantic outer shelf envi- ronments impacted by drill cutting disposal (Durrieu et al., 2006; Mojtahid et al., 2006), harbours affected by heavy metal pollution (Armynot du Châtelet et al., 2004), and eutrophicated continental shelves (Sharifi et al., 1991; Yanko and Flexer, 1991; Platon et al., 2005).

The aim of the present paper is to use an intensively studied sewage disposal site in order to assess the applicability of foraminifera as bio-indicators of this type of environmental impact and to compare the foraminiferal response with that of macrofauna. In order to do so, we will concentrate on three subjects:

(1) changes of faunal density, composition and diversity along the sample transects;

(2) the relationship between these distributional trends and varying degrees of environmental disturbance;

(3) the quantification of foraminiferal and macrofaunal responses to sewage disposal and the development of a quantitive bio-indicator method based on foraminiferal distribution.

\section{Study area}

The study area is located in the western part of Scotland in the Firth of Clyde, at a water depth varying from 58 to $178 \mathrm{~m}$ (Fig. 1, Table 1). The disposal site itself is situated at a water depth of $79 \mathrm{~m}$. Towards the north and the east, water depth remains rather stable, whereas towards the west and the south, the sea floor deepens considerably (with a maximum of $178 \mathrm{~m}$ at about $3 \mathrm{~km}$ WSW of the disposal site).

A general description of the surface sediments of the Firth of Clyde Sea was first provided by Deegan et al. 
Table 1

Geographical position of the sampling stations and their water depths

\begin{tabular}{lllll}
\hline Station & $\begin{array}{l}\text { Water } \\
\text { depth }(\mathrm{m})\end{array}$ & $\begin{array}{l}\text { Distance from the } \\
\text { disposal site }(\mathrm{km})\end{array}$ & Latitude & Longitude \\
\hline G1 & 87 & $8 \mathrm{~km}$ North-West & $55^{\circ} 43.04^{\prime} \mathrm{N}$ & $5^{\circ} 6.44^{\prime} \mathrm{W}$ \\
J7 & 79 & $2.8 \mathrm{~km}$ North & $55^{\circ} 41.29^{\prime} \mathrm{N}$ & $5^{\circ} 1.00^{\prime} \mathrm{W}$ \\
M7 & 73 & $1.2 \mathrm{~km}$ North & $55^{\circ} 40.54^{\prime} \mathrm{N}$ & $5^{\circ} 1.16^{\prime} \mathrm{W}$ \\
P4 & 154 & $2.9 \mathrm{~km}$ West & $55^{\circ} 40.27^{\prime} \mathrm{N}$ & $5^{\circ} 4.05^{\prime} \mathrm{W}$ \\
P5 & 135 & $1.8 \mathrm{~km}$ West & $55^{\circ} 40.11^{\prime} \mathrm{N}$ & $5^{\circ} 2.97^{\prime} \mathrm{W}$ \\
P7 & 79 & 0 & $55^{\circ} 39.81^{\prime} \mathrm{N}$ & $5^{\circ} 1.36^{\prime} \mathrm{W}$ \\
P8.5 & 58 & $1.5 \mathrm{~km}$ East & $55^{\circ} 39.58^{\prime} \mathrm{N}$ & $4^{\circ} 59.94^{\prime} \mathrm{W}$ \\
P10 & 75 & $3.2 \mathrm{~km}$ East & $55^{\circ} 39.34^{\prime} \mathrm{N}$ & $4^{\circ} 58.45^{\prime} \mathrm{W}$ \\
T7 & 119 & $1.7 \mathrm{~km}$ South & $55^{\circ} 38.88^{\prime} \mathrm{N}$ & $5^{\circ} 1.47^{\prime} \mathrm{W}$ \\
V7 & 178 & $2.6 \mathrm{~km}$ South & $55^{\circ} 38.41^{\prime} \mathrm{N}$ & $5^{\circ} 1.58^{\prime} \mathrm{W}$ \\
\hline
\end{tabular}

(1973), who show soft muddy sediments in the deeper areas grading into sandier sediments in areas shallower than $50 \mathrm{~m}$, admixed with gravel in the even shallower fjordic areas. The precise succession of various sedimentary facies is of course considerably more complex than this very simplified picture. The sediments in our study area are predominantly silty clays (Pearson, 1986).

The Garroch Head site was described by Pearson (1986) as a non-dispersive area from a hydrodynamic point of view. Oceanographic conditions in the vicinity of the area have been described in some detail by Dooley (1979). Residual currents over the disposal area, driven by tidal currents, are generally weak $\left(<10 \mathrm{~cm} \mathrm{~s}^{-1}\right)$. The low current velocities result in a rapid settlement of the sedimentary material present in the water column and consequently in the accumulation of important quantities of sediment enriched in organic carbon, metals and other components of anthropogenic origin. Wind driven currents, generally in a $\mathrm{SE}$ direction, with a current speed of $5-15 \mathrm{~cm} / \mathrm{s}$, cause relatively rapid renewal of the bottom water. However, both current speed and direction are variable over time. In non-impacted areas the water immediately above the sediment surface is always fully oxygenated and organic matter degradation is maintained without creation of anoxia at the sea floor (Pearson, 1986).

\section{Materials and methods}

Ten stations were sampled between the 7th and the 10th of June 1988 with the R.V. Calanus (Table 1), along two perpendicular transects centred around the disposal site (Fig. 1). Five stations were sampled along the E/W transect and five along the N/S transect (the central station, P7, being common to both transects). In addition, a reference station was sampled some $8 \mathrm{~km} \mathrm{NW}$ of the disposal area. At each sampling station, a Craib core sample (Craib, $1965)$ and a $0.1 \mathrm{~m}^{2}$ Van-Veen grab were obtained. The core samples provided material for physico-chemical analyses (Heavy metal, carbon and nitrogen, redox potential (Eh) and acidity $(\mathrm{pH})$ measurements). The top centimetre of the grab samples was analysed for the presence of benthic foraminifera and macrofaunal organisms. It has been shown that the study of the first centimetre of grab samples gives a reliable picture of the macrofauna (Heip et al., 1977). However, for small-sized organisms such as foraminifera and metazoan meiofauna, grab samples may not always be satisfactory. More specifically, part of the superficial sediment, together with the small-sized organisms inhabiting this niche, may be lost due to the bow wave generated by the impact of the sampling engine at the sea floor, or may be washed out during the recovery of the engine. In the case of foraminifera, especially epibenthic forms may be concerned (Murray, 2006). It is therefore important to realise that this potential sampling bias could be responsible for some of the differences between the foraminiferal and the macrofaunal records.

Eh and $\mathrm{pH}$ measurements were made in the Craib cores on board of the ship immediately after sampling. Measurements were made using a specially constructed electrode designed to give readings at different levels in the core in the course of stepwise penetration down to about $10 \mathrm{~cm}$ depth. The Eh electrodes had an internal reference electrode and a working length of $250 \mathrm{~mm}$ with a diameter of $10-12 \mathrm{~mm}$. The electrode was designed with a ceramic bridge to an $\mathrm{Ag} / \mathrm{AgCl}$ reference system using saturated $\mathrm{KCl}$, and had a sensing element consisting of a small platinum plug approximately $3 \mathrm{~mm}$ long and $2 \mathrm{~mm}$ in diameter. This sensing element was small enough to measure differences in a few millimetres thick sediment layers. The electrodes were made by Russell $\mathrm{pH}$ Ltd., Auchtermuchty, Fife, Scotland (Type No. CMF 2/250/Model R/2). The Eh and $\mathrm{pH}$ electrodes were mounted side by side $(10 \mathrm{~mm}$ apart) on a Palmer stand and were slowly wound down into the core. Readings were made on a digital $\mathrm{mV} / \mathrm{pH}$ meter capable of reading down to $1 \mathrm{mV}$, and were corrected by +198 to the direct reading obtained on the $\mathrm{mV}$ meter (in order to correct for the $\mathrm{Ag} / \mathrm{AgCl}$ reference system). An initial reading was made in the overlying water $10 \mathrm{~mm}$ above the sediment surface and the electrode sensing elements was then lowered to just penetrate the sediment surface, where a further reading was taken after a period of $60 \mathrm{~s}$. Thereafter, readings were taken at fixed $5 \mathrm{~mm}$ intervals to $5 \mathrm{~cm}$ depth and at $2.5 \mathrm{~cm}$ intervals to $10 \mathrm{~cm}$. Each reading was taken after period of $60 \mathrm{~s}$ needed to arrive at an equilibrium state.

Total organic carbon (excluding carbonates) and total nitrogen were analysed with a Perkin-Elmer elemental analyser (Model 240). The samples were pretreated with diluted hydrochloric acid to remove carbonates.

For metal concentration measurements, freeze-dried sediments were gently ground to a fine powder with an agate mortar and pestle. The sample ( $1 \mathrm{~g}$ dry weight) was then digested with $5 \mathrm{ml}$ concentrated nitric acid and $2 \mathrm{ml}$ of $30 \%$ hydrogen peroxide. The digest was allowed to stand at room temperature until frothing ceased and was gently heated to boiling on a hot plate and refluxed for a minimum of thirty minutes. If required, additional hydrogen peroxide was added to the cooled digest and digestion continued. After digestion, the solution was cooled, filtered, 
made up to known volume and the metal concentrations determined by atomic absorption spectrophotometry.

Temperature measurements were performed on the water overlying the sediment in the cores immediately upon their return on board the ship. Salinity was measured in water sampled in the cores, $2-5 \mathrm{~cm}$ above the sediment surface. They were returned to the laboratory, where salinity was measured using a Guildline conductivity salinometer (see Plate 1).

For the analysis of the macrofauna, the uppermost centimetre of the sediment was sampled with a stainless steel spoon, and was sieved on deck using a sieve-table with a $1 \mathrm{~mm}$ mesh. The sieve residue was stored in $4 \%$ a formaldehyde solution buffered with borax. In the laboratory, this
$>1 \mathrm{~mm}$ fraction was hand-sorted under a binocular microscope, and all organisms were identified and enumerated. Wet-weight biomass was determined for major taxonomic groups using an electronic balance.

For the study of the foraminiferal assemblages, the complete, untreated sediment of the topmost $\mathrm{cm}$ was preserved in a $4 \%$ formaldehyde solution buffered with Borax, with $1 \mathrm{~g} / 1$ Rose Bengal, in order to distinguish living specimens. In order to increase the comparability with other studies, the foraminiferal samples were sieved over sieves with $63 \mu \mathrm{m}$ and $150 \mu \mathrm{m}$ mesh sizes, and both size fractions (63-150 $\mu \mathrm{m}$ and $>150 \mu \mathrm{m})$ were studied separately. Both sieve residues were hand-sorted under a binocular microscope, and all foraminifera were identified, enumerated

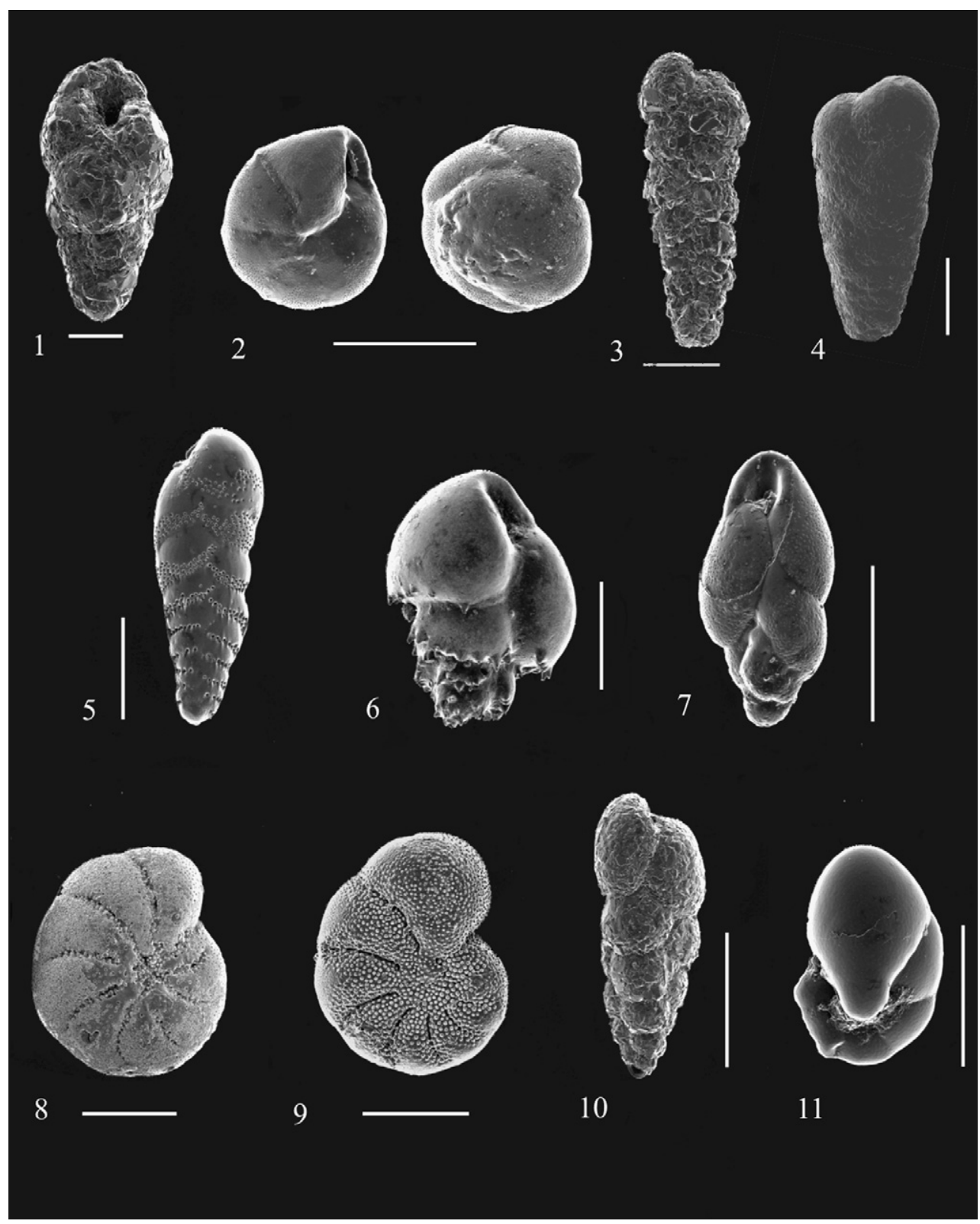

Plate 1. SEM images of the dominant foraminiferal taxa (1, Eggerella scabra; 2, Epistominella vitrea; 3, Textularia porrecta; 4, Textularia sagittula; 5, Bolivina seminuda; 6, Bulimina marginata; 7, Stainforthia concava; 8, Elphidium excavatum; 9, Elphidium albiumbilicatum; 10, Eggerella advena; 11, Nonionella turgida). Scale bar $=100 \mu \mathrm{m}$. 
and determined, using commonly used taxonomic reference works (e.g. Phleger et al., 1953; Loeblich and Tappan, 1964; Jones, 1994; etc.).

In order to better show spatial patterns of faunal variability, we applied a Principal Component Analysis (StatSoft, Inc. (2004). STATISTICA (data analysis software system), version 7. www.statsoft.com.) both to the foraminiferal $\quad(63-150 \mu \mathrm{m}$ and $>150 \mu \mathrm{m}$ fractions summed together) and macrofaunal percentage data. Only taxa occurring with more than $5 \%$ in at least one sample were retained in these PCA analyses. For each station, the Shannon-Wiener index $(H)$ (Shannon, 1948; Hayek and Buzas, 1997) was calculated according to

$H=-\sum_{i=1}^{s} p_{i} \ln P_{i}$

in which $S$ is the number of species and $p$ is the relative frequency of the $i$ th species. Fisher alpha $(\alpha)$ indices were computed using

$\alpha=n_{1} / x$

where $x$ is a constant having a value inferior to 1 and $n_{1}$ can be calculated from $N(1-x), N$ being the number of individuals (Murray, 1991).

\section{Results}

\subsection{Chemical properties of surficial sediments}

Fig. 2a presents the redox potential of the surficial sediments. Low redox values are indicative of highly reducing conditions in the sediment, brought about by the degradation of large amounts of organic matter. Since we do not dispose of oxygen measurements at the sea floor and/or within the sediment, we use redox values as a proxy for bottom-water oxygenation. At the dumping site (P7), reducing conditions (negative redox values) appear at the sediment-water interface. Sutherland et al. (2007) suggest that redox values higher than 50 characterise well oxygenated conditions, values from -50 to 50 indicate slightly oxic environments, whereas values between -50 and -150 are typical of hypoxic environments $(<2 \mathrm{mg} / 1$; Tyson and Pearson, 1991). Redox values below -150 are only found in anoxic conditions. The value of -96 , measured at station $\mathrm{P} 7$, therefore indicates strongly hypoxic conditions at the sediment-water interface. Relatively low (but positive) redox values (with respect to the base-line values found in station G1) are found until about $2 \mathrm{~km}$ from the disposal site. However, the positive redox values suggest that the sediment-water interface is well oxygenated $(>2 \mathrm{mg} / \mathrm{l})$ at all sites except station P7. At a distance of about $3 \mathrm{~km}$, redox potential values are comparable to those at the reference station (except for station $\mathbf{J} 7$ that shows a slightly lower value). In general, redox values in the most affected area were somewhat lower in June 1988 than in May 1987 (Pearson, 1988).

When we compare the redox potential profiles in the upper $10 \mathrm{~cm}$ of the sediment, the differences in redox potential between the stations become even clearer (Fig. 2b, Appendix A). In fact, at the deepest stations P4 and V7 the redox potential stays above 300 down to $4 \mathrm{~cm}$ depth, suggesting well oxygenated conditions. Reference station G1, and stations P10 and $\mathbf{J} 7$, which are equally distant

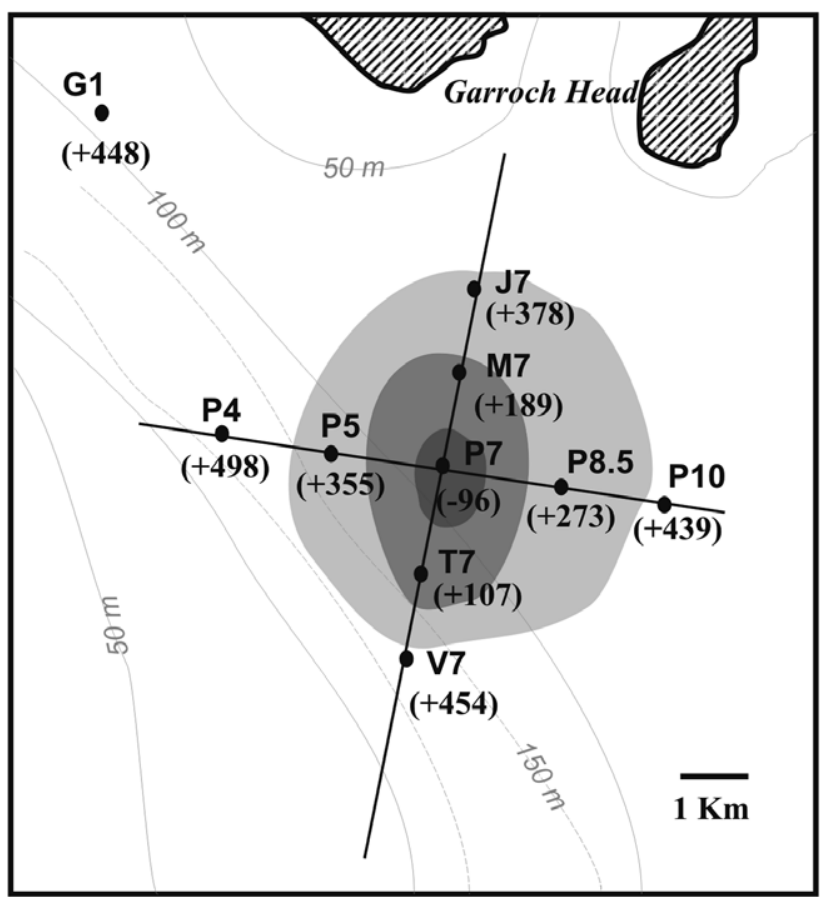

Eh (redox potential)

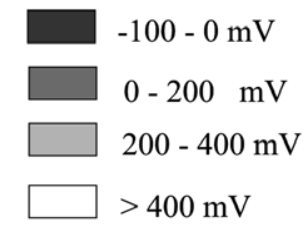

Fig. 2a. Redox potential in the surface sediment. 

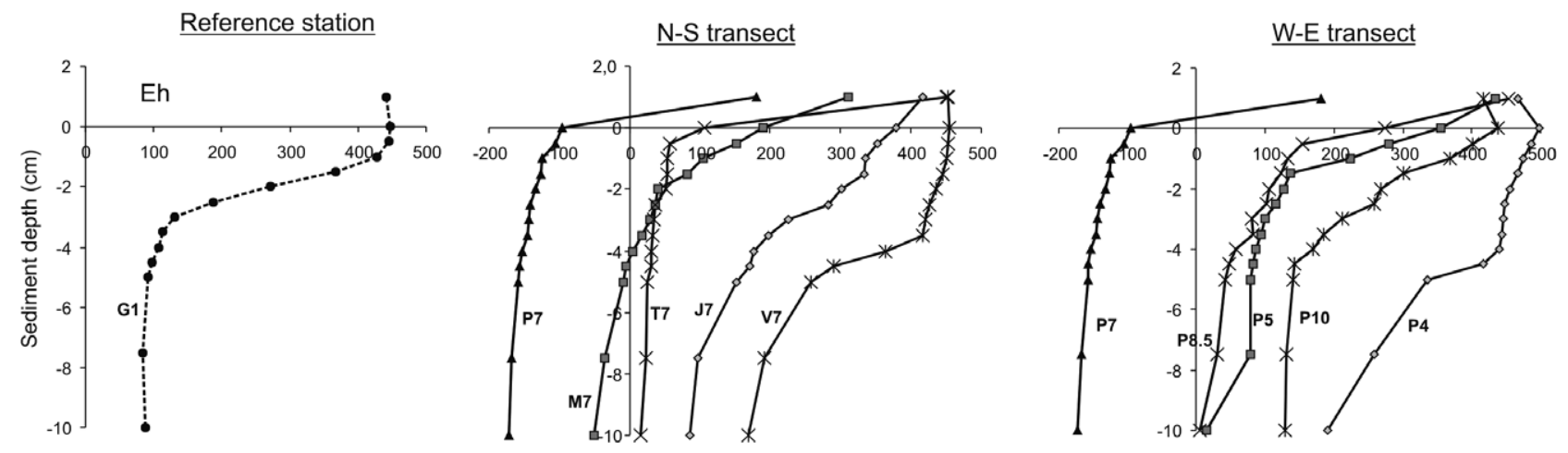

Fig. 2b. Profiles of redox potential in the sediment until $10 \mathrm{~cm}$ depth.

from the discharge point as $\mathrm{P} 4$ and $\mathrm{V} 7$, but in shallower water, appear to be well oxygenated in the upper $2 \mathrm{~cm}$, and attain an Eh of about $100-170 \mathrm{mV}$ deep in the sediment (below $5 \mathrm{~cm}$ depth). At all stations situated at about $2 \mathrm{~km}$ from the dumpsite (M7, T7, P8.5 and P5) Eh values tend to fall below $100 \mathrm{mV}$ in the top $2 \mathrm{~cm}$ of the sediment. Apparently, only the topmost sediment is well oxygenated at these sites. At the disposal site (P7), Eh values are already negative $(-96 \mathrm{mV})$ at the surface and decrease to about $-200 \mathrm{mV}$ at $10 \mathrm{~cm}$ depth, denoting strongly hypoxic conditions at the sediment-water interface, with a very limited oxic penetration into the sediment.

The $\mathrm{pH}$ at the sediment surface varies from 7.26 to 7.77 , with a minimum value at the disposal site and a maximum at reference station G1 and at station V7 (Fig. 3; Appendix A).

The results of organic carbon and nitrogen analyses are presented in Figs. 4 and 5. At the background station G1, the sediment contains $2.6 \% C_{\text {org }}$ and $0.26 \%$ total $N$. Maximal values, of $12.4 \% C_{\text {org }}$ and $1.26 \%$ total $N$, are found at the disposal site (P7). Until about $2 \mathrm{~km}$ from the disposal sites, increased $C_{\text {org }}(3-5.6 \%)$ and total $N$ values $(0.3-0.6 \%)$ are observed, especially to the east and south.

The results of metal concentration measurements are presented in Fig. 6. This shows elevated concentrations for most metals at the disposal site $\mathrm{P} 7 . \mathrm{Zn}, \mathrm{Cr}, \mathrm{Cu}$ and $\mathrm{Pb}$ are the most abundant heavy metals found in the impacted area. Concentrations of these elements (Appen-

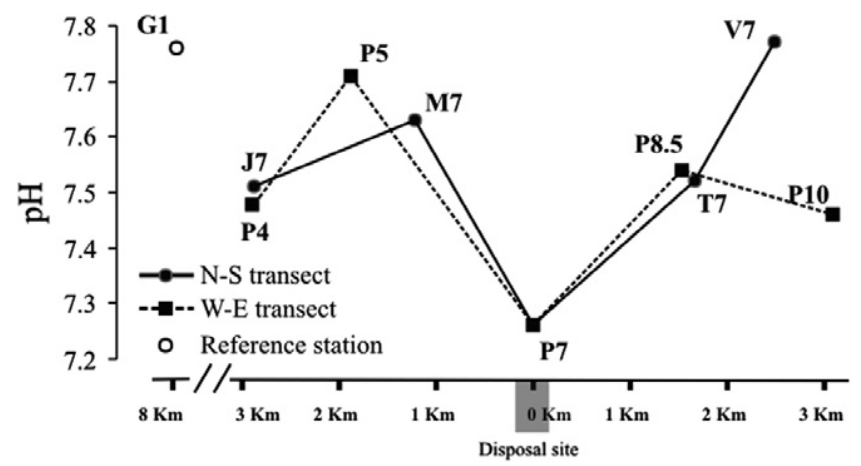

Fig. 3. Acidity of the sediment surface along the transects. dix C) are very high at the disposal site (a total of about $2500 \mathrm{mg} / \mathrm{kg}$ dry weight) and decrease progressively to the stations farthest away from the dumpsite. At the reference station, heavy metal concentrations do not exceed $500 \mathrm{mg} /$ kg dry weight. Pearson (1988) described a general tendency towards increasing metal concentrations from 1979 to 1988.

The temperature and salinity of the water immediately $(1-2 \mathrm{~cm})$ above the sediment surface were very uniform ( $T \sim 8{ }^{\circ} \mathrm{C}$ and $S \sim 34 \%$ ) in June 1988.

\subsection{Foraminiferal faunas (Appendices $E$ and $F$ )}

Generally, the living (Rose Bengal stained) faunas in the larger size fraction $(>150 \mu \mathrm{m})$ of the superficial sediment $(0-1 \mathrm{~cm})$ are relatively poor. The total number of living individuals varies from 0 at station $\mathrm{P} 7$ (disposal site) to 101 per $0.1 \mathrm{~m}^{2}$ at station P10 $(3 \mathrm{~km}$ east of the disposal site). The species richness is also low, varying from a total absence at station P7 to 9 species at station P5 ( $2 \mathrm{~km}$ west of the disposal site). In general, the fauna in the $>150 \mu \mathrm{m}$ fraction is dominated by the agglutinated species Eggerella scabra. In some of the stations, this taxon is accompanied by fair numbers of Bulimina marginata, Reophax nodulosus and Stainforthia concava (Fig. 7, Appendix E).

The faunas in the $63-150 \mu \mathrm{m}$ size fraction are nearly always much richer. The total number of individuals found in the topmost $\mathrm{cm}$ varies from 2 at station $\mathrm{P} 7$ (disposal site) to 1093 individuals $/ 0.1 \mathrm{~m}^{2}$ at station P5 $(2 \mathrm{~km}$ west of the disposal site). The species richness is also higher than in the $>150 \mu \mathrm{m}$ fraction and varies from two species at station P7 to 24 species at station P4 $(3 \mathrm{~km}$ west of the disposal site). In general, the fauna is dominated by Bulimina marginata, Eggerella scabra, Bolivina seminuda, Elphidium albiumbilicatum and Reophax nana. In some of the stations, these taxa are accompanied by Elphidium excavatum, Epistominella vitrea, Stainforthia concava, Eggerella advena, Textularia sagittula and Nonionella turgida (Fig. 8; Appendix F).

Fig. 9 summarises the variation in species richness and abundance along the $E / W$ and the $N / S$ transects for the joint $63-150 \mu \mathrm{m}$ and $>150 \mu \mathrm{m}$ fractions (Table 2). Both 


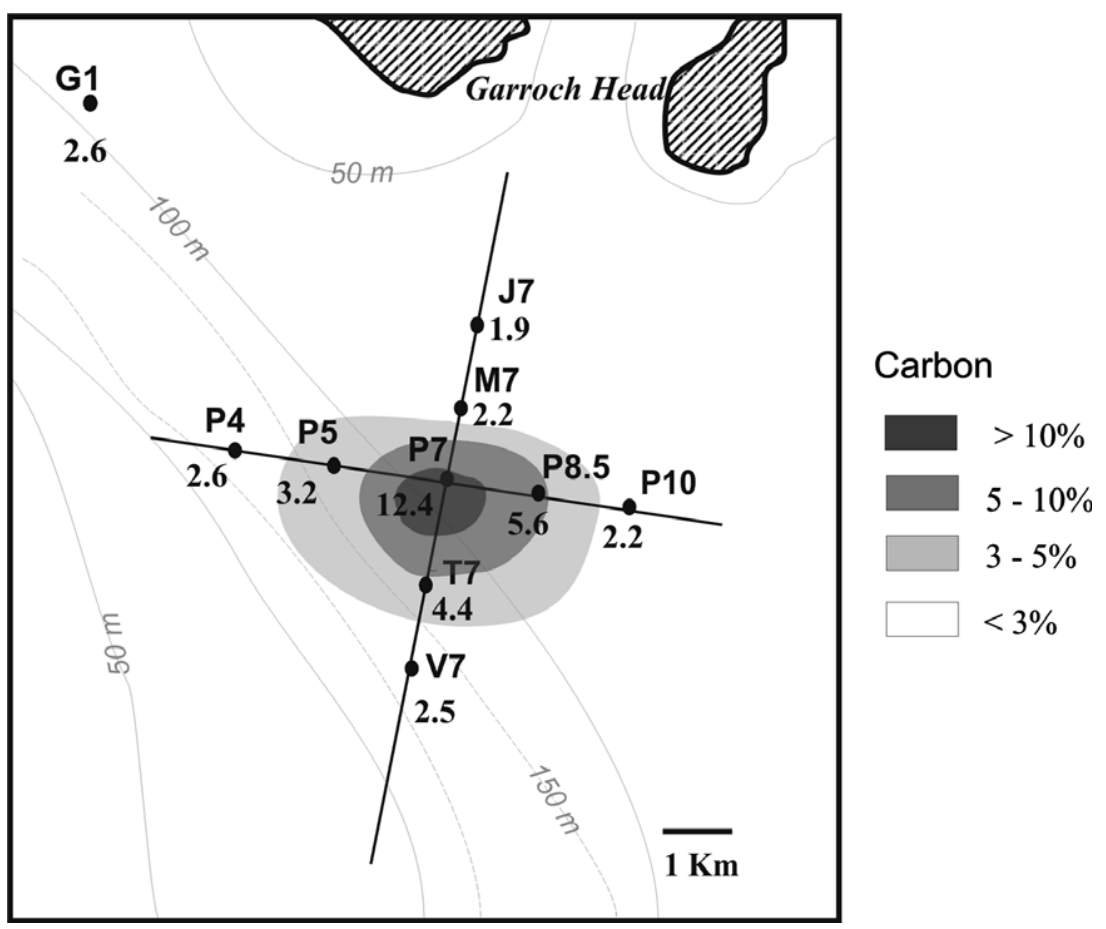

Fig. 4. Distribution of organic carbon in the surficial sediment (\%d.w.).

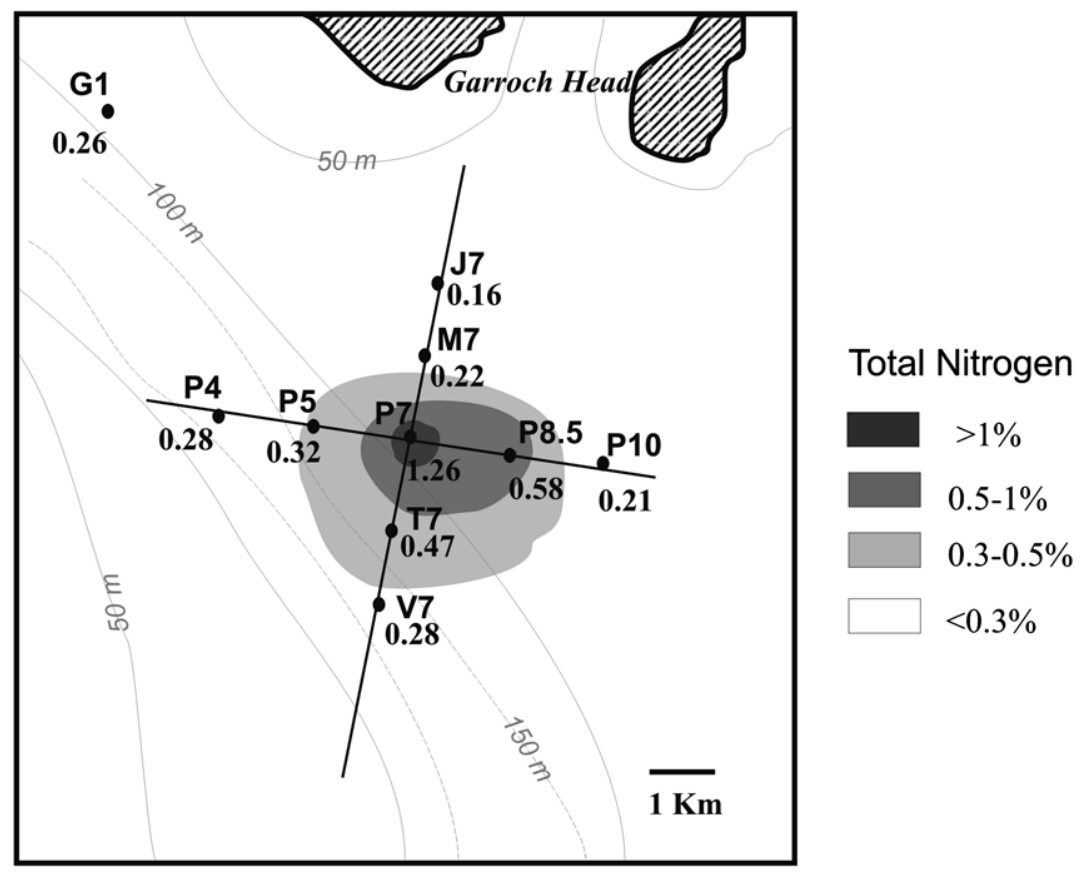

Fig. 5. Distribution of total nitrogen in the surficial sediment (\%d.w.).

parameters show a conspicuous minimum at the disposal site, which is almost azoic (only two specimens in the 63$150 \mu \mathrm{m}$ fraction). For both parameters, there is an increasing tendency towards samples situated $2-3 \mathrm{~km}$ away from the disposal site, where abundance and species richness attain values comparable to the background levels recorded at reference station G1. Shannon-Wiener and Fisher alpha diversity indices were computed on the basis of the abundance data at each station. Generally, both indices have elevated values at reference station G1, may show an increase to the stations between 1 and $2 \mathrm{~km}$ from the disposal site (especially for the Fisher alpha index), and fall to almost zero at the discharge station P7 (Fig. 10).

The PCA analysis is based on the percentage data (63$150 \mu \mathrm{m}$ and $>150 \mu \mathrm{m}$ summarised) of all taxa occurring with more than $5 \%$ in at least one sample. Station P7 

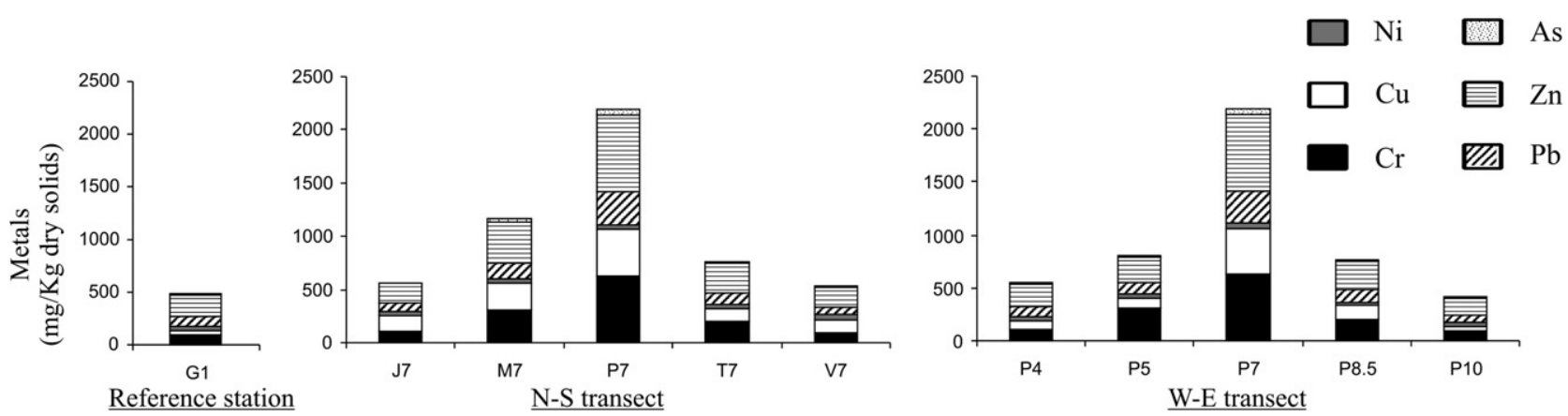

Fig. 6. Distribution of heavy metals in the sediments along the transects.

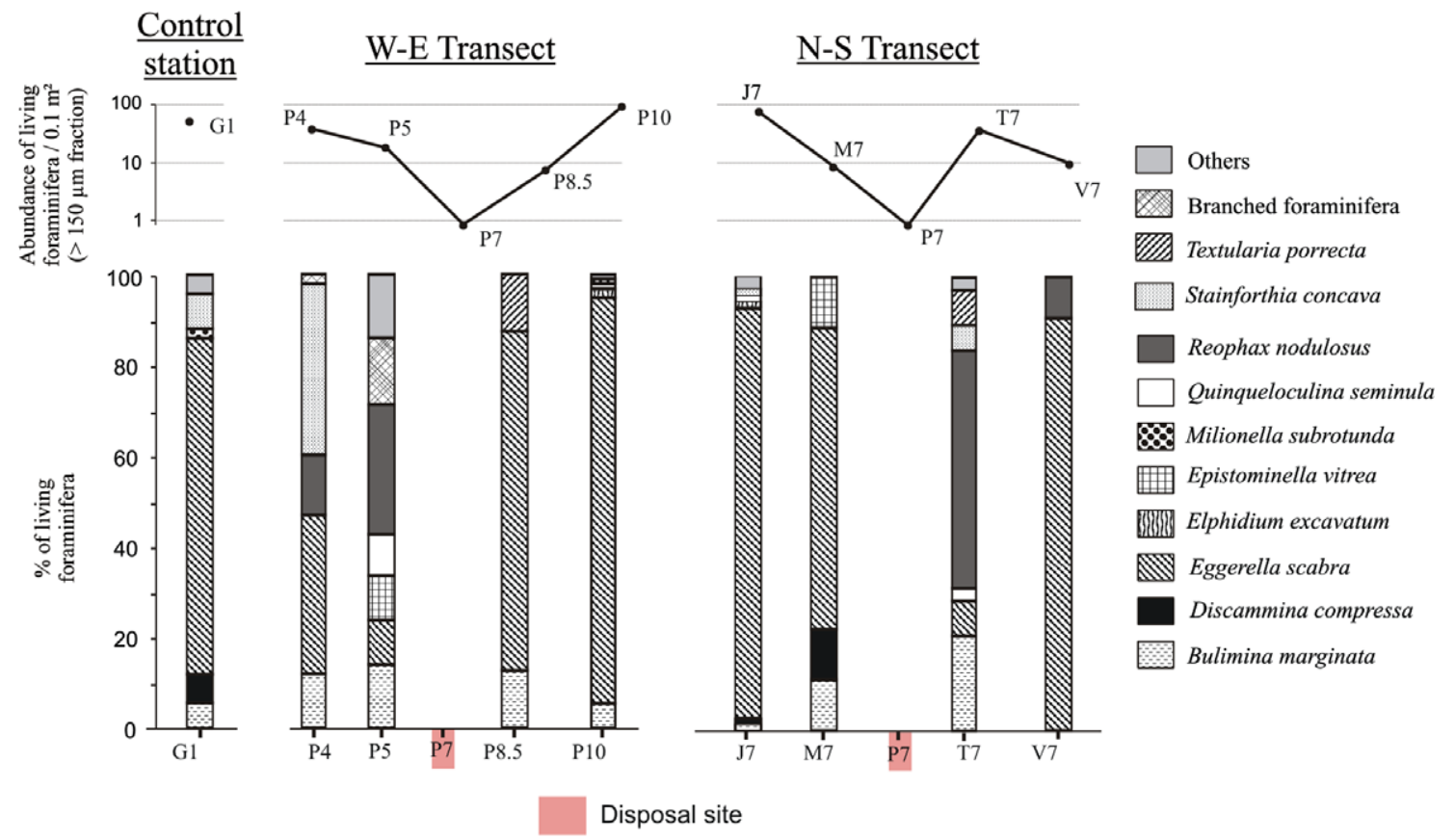

Fig. 7. Density and composition of foraminiferal faunas $\left(>150 \mu \mathrm{m}\right.$ fraction) for $0.1 \mathrm{~m}^{2}$ sediment surface.

was excluded from the database because it contains only two individuals. The results of this PCA analysis are presented in Table 3 and in Fig. 11. The first two axes (Eigenvalues 308.3 and 152.6, respectively) account for $44.73 \%$ and $22.13 \%$ of the total variation in the dataset. The cluster based on Ward's method (Fig. 11a; based on Euclidean distances) shows two groups of samples (T7, P5 and P4 versus $\mathrm{V} 7, \mathrm{~J} 7, \mathrm{P} 10$ and G1), and two isolated stations with a much weaker correlation (M7 and $\mathrm{P} 8.5$ ).

Fig. $11 \mathrm{~b}$ shows that the first PCA axis is positively loaded by Bolivina seminuda, Bulimina marginata, Stainforthia concava and Reophax nodulosus, whereas Eggerella scabra has a strong negative contribution. The second PCA axis has positive loadings of Elphidium albiumbilicatum, Bolivina seminuda, Eggerella advena, Elphidium excavatum and Nonionella turgida, whereas Epistominella vitrea, Textularia porrecta, Reophax nana, Bulimina marginata and Textularia sagittula have a negative contribution.

Fig. 11c, which shows the position of the samples on the axial plot, distinguishes the two groups of samples and two isolated sites recognised by the cluster analysis (Fig. 11). As it can be seen in Fig. 12, the fauna of station M7, with a high negative loading on axis 1 , is strongly dominated by E. scabra. On the other hand sample P8.5, with a high negative value on axis 2, has the highest values of $E$. vitrea, $T$. porrecta, $R$. nana, B. marginata and $T$. sagittula. Thus, the group of samples with a positive score on axis $1(\mathrm{P} 4$, P5 and T7) are enriched in taxa with a positive score on this axis (B. seminuda, B. marginata, S. concava and $R$. nodulosus, see Fig. 12). Finally, the group of samples with a positive score on axis 2 (G1, V7, J7 and P10) are rich in E. albiumbilicatum, E. advena, E. excavatum and N. turgida, all of which grouped together in the central part of Fig. 11b, on the positive side of axis 2 . These taxa are accompanied by E. scabra and B. seminuda, both also having a positive loading on axis 2 (Figs. 11b, and 12).

The four groups of samples recognised by the PCA analysis appear in a typical horse-shoe distribution (Fig. 11) on the factor plot (Hill and Gauch, 1980; Digby and Kempton, 1987). The control station G1 is plotted together with 


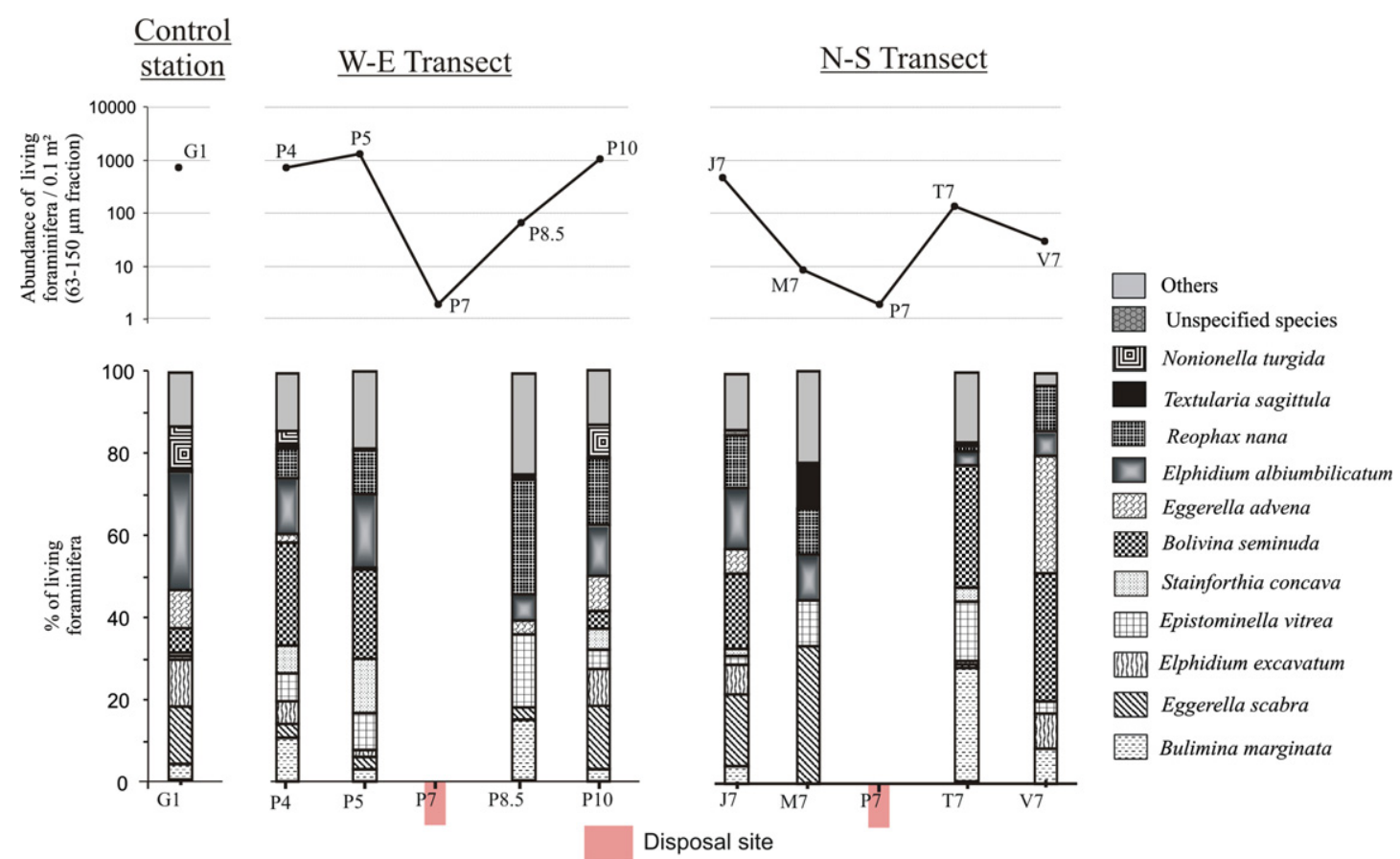

Fig. 8. Density and composition of the foraminiferal faunas $\left(63-150 \mu \mathrm{m}\right.$ fraction) for $0.1 \mathrm{~m}^{2}$ sediment surface.

stations J7, V7 and P10, 2.6-3.2 km from the disposal site, that have rather similar faunas (Fig. 12). Samples T7, P5 and $\mathrm{P} 4$, respectively at $1.7,1.8$ and $2.8 \mathrm{~km}$ from the disposal site, are distinguished by their high positive score on axis 1. Sample P8.5, $1.5 \mathrm{~km}$ south of the disposal site plots negatively on axis 2, whereas sample M7, closest to the disposal site $(1.2 \mathrm{~km} \mathrm{~N})$ plots on the negative side of axis 1 . It seems probable that this succession of samples reflects a gradient of an increasing foraminiferal response to environmental stress. In Fig. 12, where we present changes in faunal distribution, we have ordered the stations according to their position on this gradient. This ordination reflects the distance to the disposal site, with the exception of station P4 (2.8 km W of the disposal site), that is grouped together with P5 and T7, which are much closer to the disposal site (Fig. 12) Table 4.

\subsection{Macrofauna}

The macrofaunal biomass found at the sampling stations gives an overall indication of the gross effects of sludge deposition on the fauna. Table 5 summaries densities and relative abundances of the most abundant macrofaunal species that occur with more than $5 \%$ in at least one sample. Fig. 13 compares the biomass recorded in each grab sample for the stations sampled in 1988 with the average of the same stations during the previous 9 years (Pearson, 1988). The biomass at station P7 (disposal site) was much lower in 1988 than this 9 year average. Also at station P8.5, $1.5 \mathrm{~km}$ east of the disposal site, values lower than the 1979-1987 average were found. However, the large standard errors, especially at sites P7 and M7, show a large interannual variability close to the disposal site. On the northern transect, values much higher than the 1979-87 average were found at both stations (J7 and M7). Also at station P5 (1.8 km west) and P10 (3 km east) the 1988 values were higher than the 9 year average. At the other stations, the 1988 values are quite similar to the 1979-1987 average. The very low biomass $\left(1.4 \mathrm{~g} / 0.1 \mathrm{~m}^{2}\right)$ found at the disposal site (P7) suggests an increased environmental stress in comparison to the average of the 1979-1987 dataset. Very low biomass levels were also recorded at this site in $1983\left(0.8 \mathrm{~g} / 0.1 \mathrm{~m}^{2}\right)$ and in $1986\left(11.5 \mathrm{~g} / 0.1 \mathrm{~m}^{2}\right)$.

A more detailed appreciation of the overall effect of sludge deposition on the benthic fauna of the area can be obtained by the comparison of the variation in species numbers, total abundances and biomass along the transects. Fig. 14 shows the variation of these three parameters along the $\mathrm{E} / \mathrm{W}$ and the $\mathrm{N} / \mathrm{S}$ transects. All three parameters show low values in the centre of the disposal area. This area contains a limited number of individuals of nematode and annelid worms. Abundance, biomass and species richness values rise to maximum levels at the stations between 1 and $2 \mathrm{~km}$ from the disposal site, dramatically so on the northern transect where over 20,000 organisms per $0.1 \mathrm{~m}^{2}$ were recorded at station M7. Farther than $2 \mathrm{~km}$ away, these three parameters tend to decrease on both transects with the exception of station P10, where relatively high biomass levels can be observed $3 \mathrm{~km}$ from the centre and station $\mathrm{J} 7$ where a high species richness is maintained $2.8 \mathrm{~km}$ from the disposal site.

Fig. 15 illustrates the variability of the Shannon-Wiener and Fischer $\alpha$ indices across the two transects. Generally, both diversity indices are relatively high at the reference 


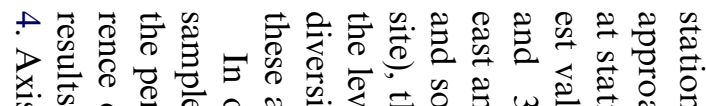

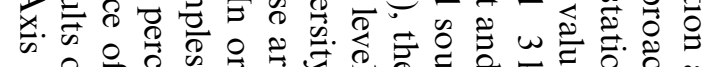
-

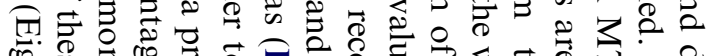

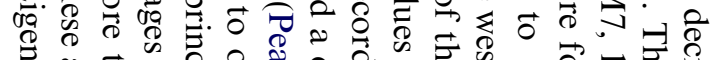
〈

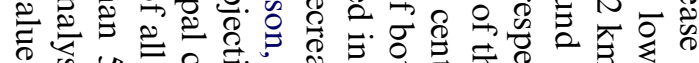
$\|$ क गे

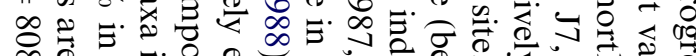
कृ

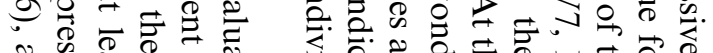

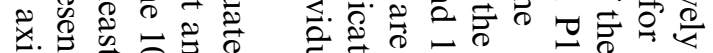

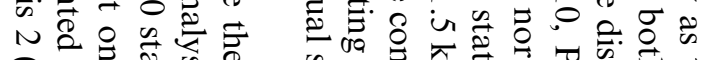
ति

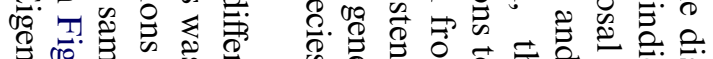
$<$ 的乡 क

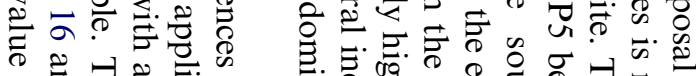

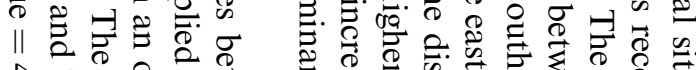
ज州

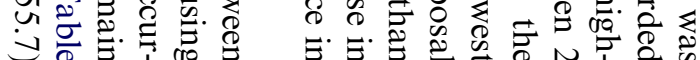
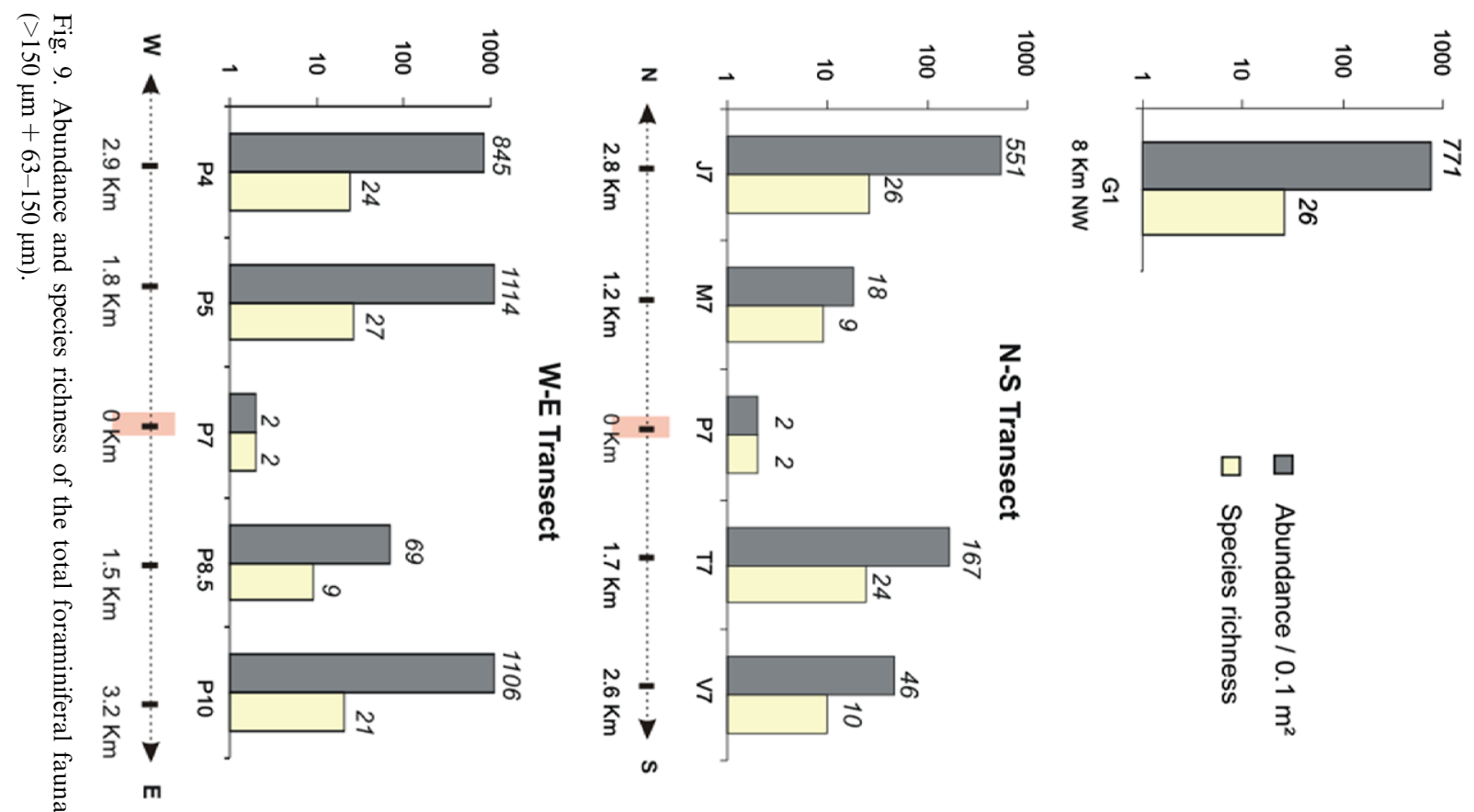

Table 2

Most abundant foraminiferal taxa recorded for each station (density for $0.1 \mathrm{~m}^{2}$ sediment surface and relative density), species richness and diversity indices (Fisher alpha and Shannon Wiener)

\begin{tabular}{|c|c|c|c|c|c|c|c|c|c|c|c|c|c|c|c|c|c|c|c|c|}
\hline \multirow{2}{*}{$\begin{array}{l}\text { Stations } \\
\text { Species }\end{array}$} & \multicolumn{2}{|l|}{ G1 } & \multicolumn{2}{|l|}{ P4 } & \multicolumn{2}{|l|}{ P5 } & \multicolumn{2}{|l|}{ P7 } & \multicolumn{2}{|l|}{$\mathrm{P} 8.5$} & \multicolumn{2}{|l|}{$\mathrm{P} 10$} & \multicolumn{2}{|l|}{ J7 } & \multicolumn{2}{|l|}{ M7 } & \multicolumn{2}{|l|}{$\mathrm{T} 7$} & \multicolumn{2}{|l|}{ V7 } \\
\hline & $\mathrm{A}$ & $\%$ & A & $\%$ & $\mathrm{~A}$ & $\%$ & $\mathrm{~A}$ & $\%$ & $\mathrm{~A}$ & $\%$ & A & $\%$ & $\mathrm{~A}$ & $\%$ & $\mathrm{~A}$ & $\%$ & $\mathrm{~A}$ & $\%$ & $\mathrm{~A}$ & $\%$ \\
\hline Bolivina seminuda & 43 & 5.6 & 200 & 23.7 & 241 & 21.6 & 1 & 50.0 & & 0.0 & 44 & 4.0 & 87 & 15.8 & & & 39 & 23.4 & 11 & 23.9 \\
\hline Bulimina marginata & 31 & 4.0 & 89 & 10.5 & 37 & 3.3 & & & 10 & 14.5 & 35 & 3.2 & 21 & 3.8 & 1 & 5.6 & 44 & 26.3 & 3 & 6.5 \\
\hline Eggerella advena & 68 & 8.8 & 20 & 2.4 & 5 & 0.4 & & & 2 & 2.9 & 84 & 7.6 & 27 & 4.9 & & & & & 10 & 21.7 \\
\hline Eggerella scabra & 138 & 17.9 & 43 & 5.1 & 32 & 2.9 & & & 8 & 11.6 & 244 & 22.1 & 156 & 28.3 & 9 & 50.0 & 4 & 2.4 & 10 & 21.7 \\
\hline $\begin{array}{l}\text { Elphidium } \\
\text { albiumbilicatum }\end{array}$ & 210 & 27.2 & 108 & 12.8 & 197 & 17.7 & & & 4 & 5.8 & 123 & 11.1 & 71 & 12.9 & 1 & 5.6 & 4 & 2.4 & 2 & 4.3 \\
\hline $\begin{array}{l}\text { Elphidium } \\
\quad \text { excavatum }\end{array}$ & 85 & 11.0 & 44 & 5.2 & 20 & 1.8 & & & & 0.0 & 96 & 8.7 & 35 & 6.4 & & & 1 & 0.6 & 3 & 6.5 \\
\hline Epistominella vitrea & 4 & 0.5 & 56 & 6.6 & 100 & 9.0 & & & 11 & 15.9 & 43 & 3.9 & 11 & 2.0 & 2 & 11.1 & 19 & 11.4 & 1 & 2.2 \\
\hline Nonionella turgida & 75 & 9.7 & 28 & 3.3 & 5 & 0.4 & & & & 0.0 & 79 & 7.1 & 6 & 1.1 & & & & & & \\
\hline Reophax nana & 4 & 0.5 & 60 & 7.1 & 113 & 10.1 & & & 17 & 24.6 & 167 & 15.1 & 59 & 10.7 & 1 & 5.6 & 2 & 1.2 & 4 & 8.7 \\
\hline Reophax nodulosus & 11 & 1.4 & 8 & 0.9 & 6 & 0.5 & & & & 0.0 & 10 & 0.9 & 5 & 0.9 & & & 20 & 12.0 & 1 & 2.2 \\
\hline Stainforthia concava & 11 & 1.4 & 72 & 8.5 & 143 & 12.8 & & & & 0.0 & 54 & 4.9 & 9 & 1.6 & & & 6 & 3.6 & & \\
\hline Textularia porrecta & 11 & 1.4 & 20 & 2.4 & 84 & 7.5 & 1 & 50.0 & 13 & 18.8 & 65 & 5.9 & 21 & 3.8 & 1 & 5.6 & 5 & 3.0 & & \\
\hline Textularia sagittula & & & 4 & 0.5 & 1 & 0.1 & & & 1 & 1.4 & & & & & 1 & 5.6 & 1 & 0.6 & & \\
\hline Others & 80 & 10.4 & 93 & 11.0 & 130 & 11.7 & & & 3 & 4.3 & 62 & 5.6 & 43 & 7.8 & 2 & 11.1 & 22 & 13.2 & 1 & 2.2 \\
\hline Total & 771 & & 845 & & 1114 & & 2 & & 69 & & 1106 & & 551 & & 18 & & 167 & & 46 & \\
\hline Number of species & 26 & & 24 & & 27 & & 2 & & 9 & & 21 & & 26 & & 9 & & 24 & & 10 & \\
\hline Fisher alpha & 5.19 & & 4.59 & & 4.98 & & 0.00 & & 2.76 & & 3.67 & & 5.66 & & 7.16 & & 7.68 & & 3.93 & \\
\hline Shannon-Wiener & 2.35 & & 2.57 & & 2.44 & & 0.69 & & 1.95 & & 2.45 & & 2.34 & & 1.71 & & 2.29 & & 1.96 & \\
\hline
\end{tabular}




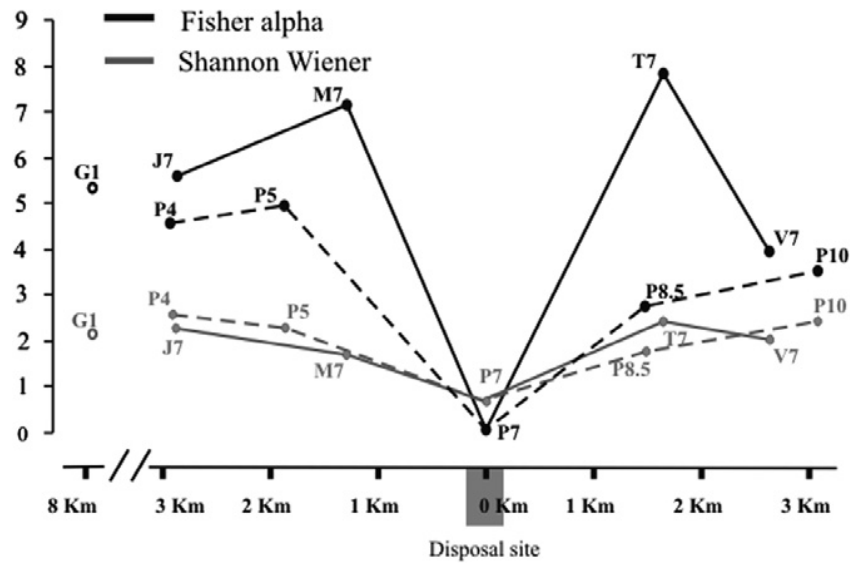

Fig. 10. Fisher alpha index and Shannon-Wiener index of benthic foraminifera along NS and WE transects.

and axis 3 (Eigenvalue $=423.6$ ) account respectively for $44.4 \%, 25.0 \%$ and $23.3 \%$ of the total variation in the data-
Table 3

Results of the foraminiferal PCA analysis

\begin{tabular}{lcclc}
\hline $\begin{array}{l}\text { Value } \\
\text { number }\end{array}$ & Eigenvalue & $\begin{array}{l}\text { \% Total } \\
\text { variance }\end{array}$ & $\begin{array}{l}\text { Cumulative } \\
\text { eigenvalue }\end{array}$ & $\begin{array}{l}\text { Cumulative } \\
(\%)\end{array}$ \\
\hline 1 & 308.30 & 44.73 & 308.30 & 44.73 \\
2 & 152.56 & 22.13 & 460.86 & 66.86 \\
3 & 109.55 & 15.89 & 570.41 & 82.75 \\
4 & 62.60 & 9.08 & 633.02 & 91.83 \\
5 & 41.12 & 5.97 & 674.13 & 97.80 \\
6 & 7.89 & 1.15 & 682.03 & 98.94 \\
7 & 5.44 & 0.79 & 687.46 & 99.73 \\
8 & 1.85 & 0.27 & 689.31 & 100.00 \\
\hline
\end{tabular}

set (Table 4). The cluster diagram based on Ward's method (Euclidean distances) shown in Fig. 16a, separates our 10 stations into two distinct groups and two separate samples. This separation is confirmed by the axial plots (Figs. 16d and 16e). Axis 1 is positively loaded by the polychaetes Tubificoides benedeni and Capitella capitata, and by nematode worms, and is negatively loaded by the polychaetes
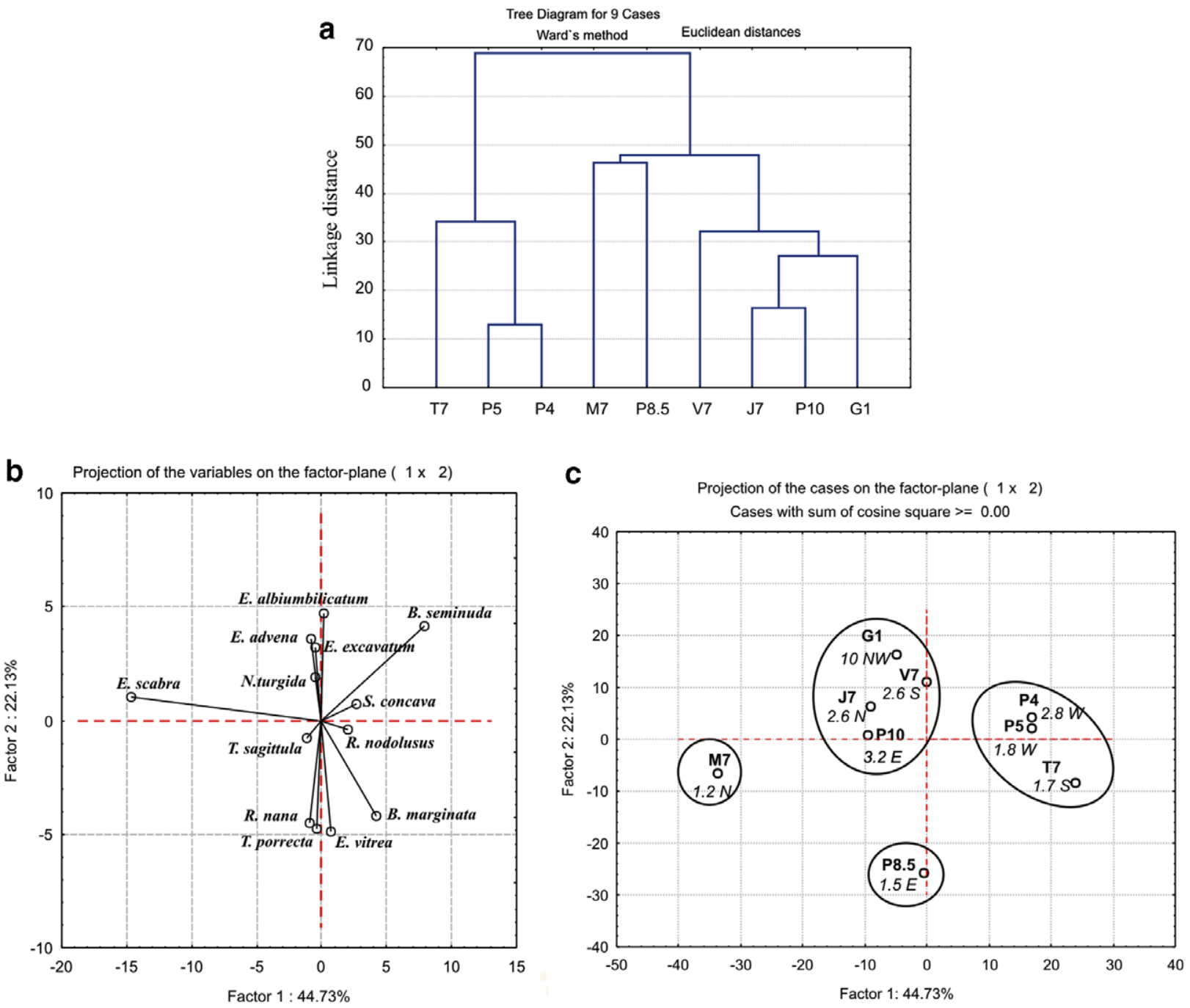

Fig. 11. PCA analysis. (a) Cluster according to euclidean distances. (b) Projection of the variables (foraminifera) on the two main PCA axes. (c) Plot of the 10 stations on the two main PCA axes, and four distinct assemblages (indicated by the dotted lines). 
Table 4

Results of the macrofaunal PCA analysis

\begin{tabular}{lcccc}
\hline $\begin{array}{l}\text { Value } \\
\text { number }\end{array}$ & $\begin{array}{l}\text { Eigen } \\
\text { value }\end{array}$ & $\begin{array}{l}\text { \% Total } \\
\text { variance }\end{array}$ & $\begin{array}{l}\text { Cumulative } \\
\text { eigenvalue }\end{array}$ & $\begin{array}{l}\text { Cumulative } \\
(\%)\end{array}$ \\
\hline 1 & 808.65 & 44.43 & 808.65 & 44.43 \\
2 & 455.67 & 25.03 & 1264.32 & 69.46 \\
3 & 423.64 & 23.28 & 1687.96 & 92.74 \\
4 & 58.32 & 3.20 & 1746.28 & 95.94 \\
5 & 29.57 & 1.62 & 1775.84 & 97.57 \\
6 & 18.67 & 1.03 & 1794.51 & 98.59 \\
7 & 16.24 & 0.89 & 1810.75 & 99.49 \\
8 & 5.07 & 0.28 & 1815.83 & 99.76 \\
9 & 4.30 & 0.24 & 1820.13 & 100.00 \\
\hline
\end{tabular}

Mediomastus fragilis, Cirratulus cirratus and the bivalves Nucula spp. and Abra alba. Samples M7 and P7, where the faunas are heavily dominated by taxa loading positively on the first axis (Fig. 16b) are therefore positioned on the positive side of axis 1 , whereas all other samples, where these species have much lower percentages (Fig. 17), plot on the negative side of axis 1 . The positive side of PCA axis 2 is dominated by the bivalves Nucula spp. and A. alba, and the polychaete Spiophanes kroyeriand a large group of subsidiary taxa. The polychaetes $M$. fragilis, $C$. cirratus, C. capitata and the nematodes have negative loadings on this axis. Fig. 16b shows that this second axis separates

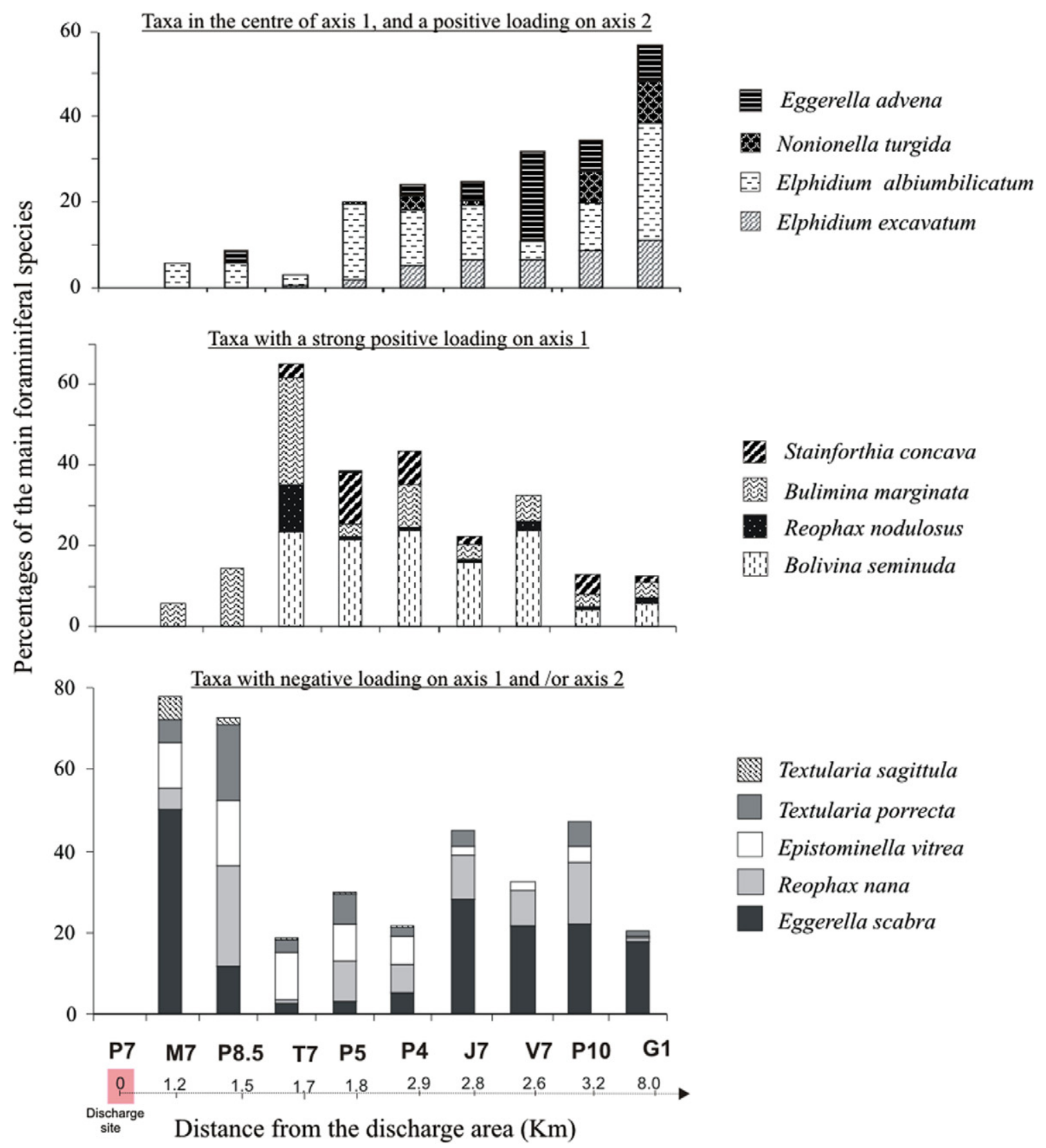

Fig. 12. Change in dominant species of total benthic foraminifera $(>5 \%)$. 
Table 5

Most abundant macrofaunal taxa recorded for each station (density for $0.1 \mathrm{~m}^{2}$ sediment surface and relative density), species richness and diversity indices (Fisher alpha and Shannon Wiener)

\begin{tabular}{|c|c|c|c|c|c|c|c|c|c|c|c|c|c|c|c|c|c|c|c|c|}
\hline \multirow[t]{2}{*}{ Species } & \multicolumn{2}{|l|}{$\mathrm{P} 7$} & \multicolumn{2}{|l|}{ M7 } & \multicolumn{2}{|l|}{$\mathrm{P} 8.5$} & \multicolumn{2}{|l|}{$\mathrm{T} 7$} & \multicolumn{2}{|l|}{$\mathrm{P} 5$} & \multicolumn{2}{|l|}{ V7 } & \multicolumn{2}{|l|}{$\mathrm{J} 7$} & \multicolumn{2}{|l|}{$\mathrm{P} 4$} & \multicolumn{2}{|l|}{$\mathrm{P} 10$} & \multicolumn{2}{|l|}{ G1 } \\
\hline & $\mathrm{A}$ & $\%$ & $\mathrm{~A}$ & $\%$ & $\bar{A}$ & $\%$ & $\mathrm{~A}$ & $\%$ & $\mathrm{~A}$ & $\%$ & $\overline{\mathrm{A}}$ & $\%$ & $\mathrm{~A}$ & $\%$ & $\mathrm{~A}$ & $\%$ & $\mathrm{~A}$ & $\%$ & $\bar{A}$ & $\%$ \\
\hline Abra alba (mollusc bivalve) & & & & & 26 & 2.7 & 4 & 0.2 & 4 & 0.5 & 4 & 1.8 & 65 & 15.0 & 15 & 12.7 & 28 & 17.5 & 1 & 1.7 \\
\hline $\begin{array}{l}\text { Ameana spp. (annelid } \\
\text { polychaete) }\end{array}$ & & & & & 3 & 0.3 & 17 & 0.7 & 53 & 8.0 & 9 & 3.8 & 4 & 0.9 & 4 & 3.0 & & & 3 & 5.2 \\
\hline $\begin{array}{l}\text { Amphiura filiformis } \\
\text { (echinoderm) }\end{array}$ & & & & & & & & & 3 & 0.5 & 12 & 5.3 & 2 & 0.3 & 3 & 2.1 & 5 & 3.2 & & \\
\hline $\begin{array}{l}\text { Capitella capitata } \\
\quad \text { (annelid polychaete) }\end{array}$ & 66 & 38.3 & 1724 & 7.5 & 7 & 0.8 & 81 & 3.6 & & & & & 7 & 1.6 & & & 1 & 0.3 & 1 & 0.9 \\
\hline $\begin{array}{l}\text { Cirratulus cirratus } \\
\quad \text { (annelid polychaete) }\end{array}$ & & & 24 & 0.1 & 173 & 18.5 & 214 & 9.5 & 53 & 8.0 & & & & & & & & & & \\
\hline $\begin{array}{l}\text { Corbula gibba (mollusc } \\
\text { bivalve) }\end{array}$ & & & & & 1 & 0.1 & & & 10 & 1.4 & 11 & 4.9 & 3 & 0.7 & 8 & 6.8 & & & & \\
\hline $\begin{array}{l}\text { Mediomastus fragilis } \\
\quad \text { (annelid polychaete) }\end{array}$ & 1 & 0.6 & 248 & 1.1 & 346 & 37.1 & 1222 & 54.5 & 197 & 29.9 & 28 & 12.4 & 7 & 1.5 & 7 & 5.5 & 3 & 1.6 & 2 & 2.6 \\
\hline $\begin{array}{l}\text { Melinna palmata } \\
\quad \text { (annelid polychaete) }\end{array}$ & & & & & 3 & 0.3 & 117 & 5.2 & 3 & 0.5 & 1 & 0.2 & & & & & & & & \\
\hline Nematoda & 90 & 51.9 & 1044 & 4.6 & 85 & 9.1 & 121 & 5.4 & & & & & 4 & 0.9 & & & & & 1 & 0.9 \\
\hline $\begin{array}{l}\text { Nucula spp. (mollusc } \\
\text { bivalve) }\end{array}$ & & & 1 & 0.0 & 1 & 0.1 & 8 & 0.4 & 19 & 2.9 & 44 & 19.5 & 93 & 21.4 & 12 & 10.1 & 43 & 27.1 & 15 & 26.1 \\
\hline Ophiura albida (echinoderm) & & & & & 2 & 0.2 & 13 & 0.6 & 14 & 2.1 & 18 & 8.0 & 3 & 0.7 & & & 2 & 1.3 & & \\
\hline $\begin{array}{l}\text { Pectinaria koreni (annelid } \\
\text { polychaete) }\end{array}$ & & & & & & & & & 1 & 0.1 & & 0.0 & 26 & 5.9 & & & 1 & 0.3 & 1 & 0.9 \\
\hline $\begin{array}{l}\text { Polyphisia crassa } \\
\quad \text { (annelid polychaete) }\end{array}$ & & & 11 & 0.0 & 5 & 0.5 & 205 & 9.1 & 70 & 10.5 & 3 & 1.1 & 5 & 1.0 & 13 & 10.5 & 10 & 6.4 & 1 & 0.9 \\
\hline $\begin{array}{l}\text { Rhodine loveni } \\
\quad \text { (annelid polychaete) }\end{array}$ & & & & & & & & & & & 3 & 1.1 & 4 & 0.8 & & & 9 & 5.7 & 4 & 6.1 \\
\hline $\begin{array}{l}\text { Spiophanes kroyeri } \\
\quad \text { (annelid polychaete) }\end{array}$ & & & & & & & 10 & 0.4 & 14 & 2.0 & 13 & 5.5 & 23 & 5.2 & 6 & 5.1 & 4 & 2.5 & 14 & 24.3 \\
\hline $\begin{array}{l}\text { Terebellides stroemi } \\
\quad \text { (annelid polychaete) }\end{array}$ & & & & & 1 & 0.1 & 1 & 0.0 & 10 & 1.5 & 2 & 0.7 & 2 & 0.5 & 9 & 7.2 & 5 & 2.9 & 1 & 1.7 \\
\hline $\begin{array}{l}\text { Tubificoides benedeni } \\
\quad \text { (annelid polychaete) }\end{array}$ & 12 & 6.7 & 19808 & 86.4 & 14 & 1.5 & 4 & 0.2 & & & 1 & 0.2 & 43 & 9.8 & & & & & & \\
\hline Others & 5 & 2.6 & 69 & 0.3 & 270 & 28.9 & 226 & 10.1 & 211 & 32.0 & 65 & 28.5 & 145 & 33.6 & 43 & 35.9 & 49 & 31.2 & 17 & 28.7 \\
\hline $\begin{array}{l}\text { A: Abundance } \\
\quad\left(\text { total per } 0.1 \mathrm{~m}^{2} \text { ) }\right.\end{array}$ & 173 & & 22,929 & & 933 & & 2241 & & 660 & & 226 & & 432 & & 119 & & 157 & & 58 & \\
\hline Number of species & 10 & & 15 & & 60 & & 53 & & 72 & & 51 & & 64 & & 37 & & 8 & & 30 & \\
\hline Fisher alpha index & 2.31 & & 1.56 & & 14.31 & & 9.73 & & 20.58 & & 20.51 & & 20.76 & & 18.46 & & 15.93 & & 25.3 & \\
\hline Shannon-Wiener index & 1.06 & & 0.54 & & 2.41 & & 1.85 & & 2.98 & & 3.24 & & 3.17 & & 3.10 & & 2.90 & & 2.68 & \\
\hline
\end{tabular}




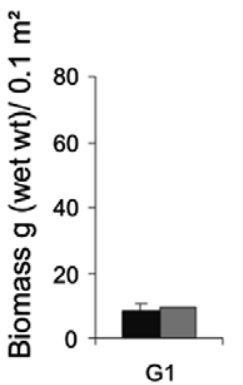

Reference station
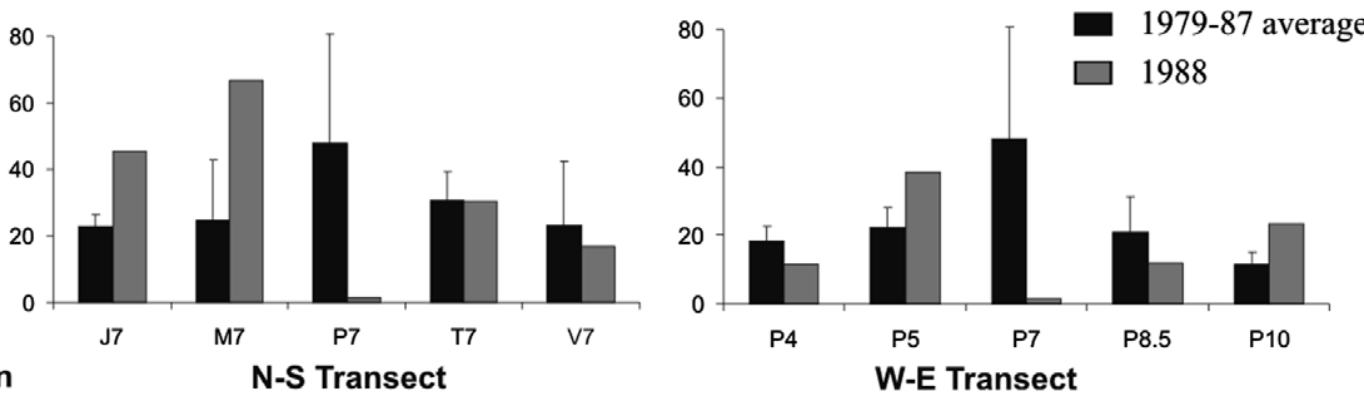

Fig. 13. Comparison of macrofaunal biomass in 1988 with the average value of the 1979-1987 period.
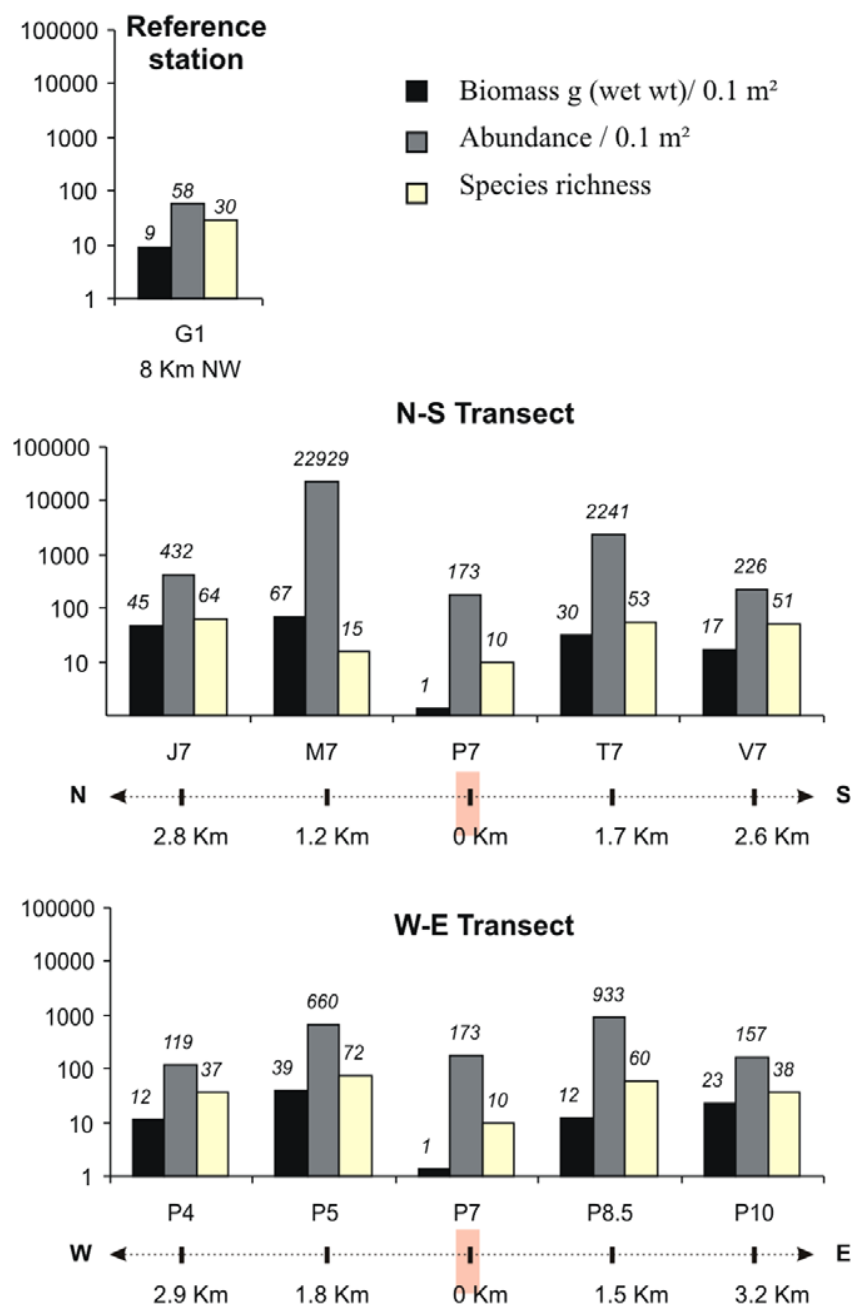

Fig. 14. Spatial variability of the major macrofaunal parameters along the $\mathrm{E} / \mathrm{W}$ and $\mathrm{N} / \mathrm{S}$ transects and in the control station. S, total number of species per $0.1 \mathrm{~m}^{2}$. (a) total abundance per $0.1 \mathrm{~m}^{2}$ (number of individuals); (b) total biomass per $0.1 \mathrm{~m}^{2}$.

samples G1, J7, P10, P4 and V7, with faunas similar to those found at control station G1 (Fig. 17), from samples P5, P8.5 and T7, that are strongly enriched in M. fragilis, C. cirratus, and Melinna palmata (Fig. 17). Axis 3, finally, that still accounts for $23.3 \%$ of the total variability is positively loaded by nematodes and C. capitata, and negatively by $M$. fragilis and $T$. benedeni. It allows a better separation between stations P7 and M7.

Just as we observed for benthic foraminiferal faunas, the position of the samples on the factor plot reflects a gradient of increasing environmental impact, from the cluster with G1 (control station), P10, J7, P4 and V7, to the cluster of stations P5, P8.5 and T7, to sample M7, to end with sample P7, at the disposal site. In Fig. 17, which presents the faunal composition, the samples are presented in this order, that also represents the distance to the disposal site. The succession pictured in Fig. 17 shows the dominance of larger macrofaunal elements (bivalves, echinoderms) at the stations farthest away from the disposal site, gradually changing into a dominance of small-sized animals (annelids, nematodes) when the centre of the disposal site is approached.

\section{Discussion}

\subsection{Foraminiferal response to sewage sludge disposal}

The sediments of the Garroch Head are predominantly fine silty clays with a natural organic carbon content of about $2-2.5 \%$. In the centre of the disposal area, this value increases to a maximum of $12 \%$. This high carbon content in the centre of the dumping area coincides with reduced conditions (negative redox potential), a high acidity and elevated nutrients and heavy metal concentrations.

The faunal distribution in the areas subjected to sewage sludge deposition allows us to draw some conclusions about the effects of sewage deposition. In addition, on the basis of these conclusions concerning the risk of sludge disposal in this type of marine environment, certain recommendations can be made. The anthropogenic detrital input at the disposal site is huge. Organic enrichment and oxygen depletion in the bottom water are likely to co-occur and to have an adverse effect on the benthic faunas. We expect increased growth of some opportunistic taxa in enriched environments and decreased growth and increased mortality in response to hypoxia. It is particularly important to quantify the interactions between these factors (organic enrichment and oxygen depletion) in order to understand their effect on benthic ecosystems. 


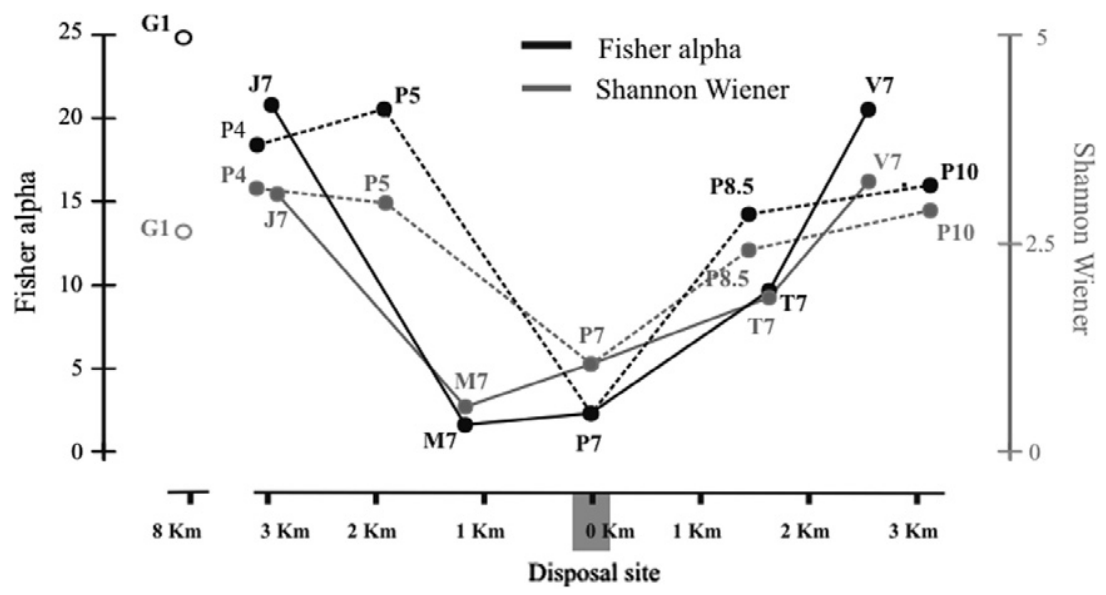

Fig. 15. Fisher alpha index and Shannon-Wiener index of macrofauna along NS and WE transects.

Foraminiferal changes, caused by an increased supply of human-induced nutrients and seasonal bottom water hypoxia, have been noted in coastal seas around the world. The nutrient increase leads in some places to a strong dominance of the agglutinated faunal component (Nagy and Alve, 1987; Alve, 1991a, 1995b) or, more generally, to an increase in abundance of opportunistic species (Nagy and Alve, 1987; Alve, 1991 b). Moreover, foraminiferal assemblages in the vicinity of sewage outfalls are characterized by a large number of specimens and low diversity (Bandy et al., 1964; Bandy et al., 1965; Alve, 1995c; Thomas et al., 2000). For example, after the development of sawmills (1550-1870), human-derived organic material caused oxygen depletion with occasional anoxia in fjordic areas of the Norwegian Skagerrak (Alve, 2000). Barmawidjaja et al. (1995) studied changes in foraminiferal assemblages influenced by the supply of human-derived nutrients to the northern Adriatic sea, and concluded that the increasing nutrient load and consequent stress led to the increase in abundance of a number of stress-tolerant taxa (e.g., Nonionella turgida, Hopkinsina pacifica, Bolivina seminuda). Platon et al. (2005) suggested that historical changes in the foraminiferal community in the Louisiana Bight were related to the increase in nutrients and bottom water hypoxia over the last 100 years. In this area, the genus Quinqueloculina nearly became extinct due to hypoxia, whereas several hyaline taxa, such as Nonionella basiloba, Buliminella morgani and Epistominella vitrea, tolerated the increase of hypoxia in the Louisiana Bight over the last 100 years (Platon et al., 2005). Few studies investigating the relationship between eutrophication and faunas have been conducted in inner bays, which have more stable natural environmental conditions than estuaries, and are characterised by high sedimentation rates that allow high-resolution studies (Tsujimoto et al., 2006). In most benthic environments, the oxygen concentration is limiting benthic life; low oxygen values are responsible for low faunal densities within the sediment of some of the most organic-rich areas. In the Adriatic Sea, as soon as the oxygen concentration rises above a critical threshold value, food availability becomes the limiting factor, regulating abundance and species composition of the benthic faunas (Jorissen et al., 1992). Areas with a high downward organic flux but still bearable oxygen levels are characterized by a number of highly opportunistic taxa, which can be epifaunal as well as potentially (mobile) infaunal (Jorissen et al., 1992). These taxa are capable of profiting from the combination of high food availability and fair oxygen levels after the reoxygenation of the bottom environment in autumn. The areas with lower organic fluxes are characterized by a more stable fauna, consisting of less stress-tolerant epifaunal taxa in combination with less mobile infaunal species, which lack the possibility to track critical oxygen levels (Jorissen et al., 1992). In our study, a very similar distribution is observed and the density and the composition of the living foraminiferal faunas allow us to subdivide the studied area into four distinct zones (Fig. 18).

Zone 1 groups stations $\mathrm{J} 7, \mathrm{~V} 7$ and P10. Stations $\mathrm{J} 7$ and P10 contain high foraminiferal densities. The faunas at these stations, localised at about $3 \mathrm{~km}$ from the dumpsite are dominated by species that are typical for the faunas at reference station G1 (Elphidium excavatum/albiumbilicatum, Nonionella turgida, Eggerella scabra/advena). These taxa are accompanied in fair proportions by species considered in the literature as opportunistic (Bolivina seminuda, Bulimina marginata; e.g. Langezaal et al., 2006; Lutze and Colbourn, 1984) and/or tolerant to oxygen depletion (Reophax nana, Epistominella vitrea and Textularia spp.).

Elphidium excavatum is an eutrophic species described in various coastal marine ecosystems by Murray (1991). It is also capable to successfully develop in polluted environments (Schafer, 1973; Buckley et al., 1974; Schafer et al., 1975; Bates and Spencer, 1979; in Alve, 1991a). Elphidium albiumbilicatum has been recorded living in shallow and deeper fjordic areas, with very variable conditions (e.g. Alve, 1995a: depth 5-46 m, temperature $1.6-18.0^{\circ} \mathrm{C}$, salinity $0.1-31.5 \%$; Gustafsson and Nordberg, 1999: depth 28 $43 \mathrm{~m}$, temperature $3-5^{\circ} \mathrm{C}$, salinity $26 \%$; Gustafsson and 
a
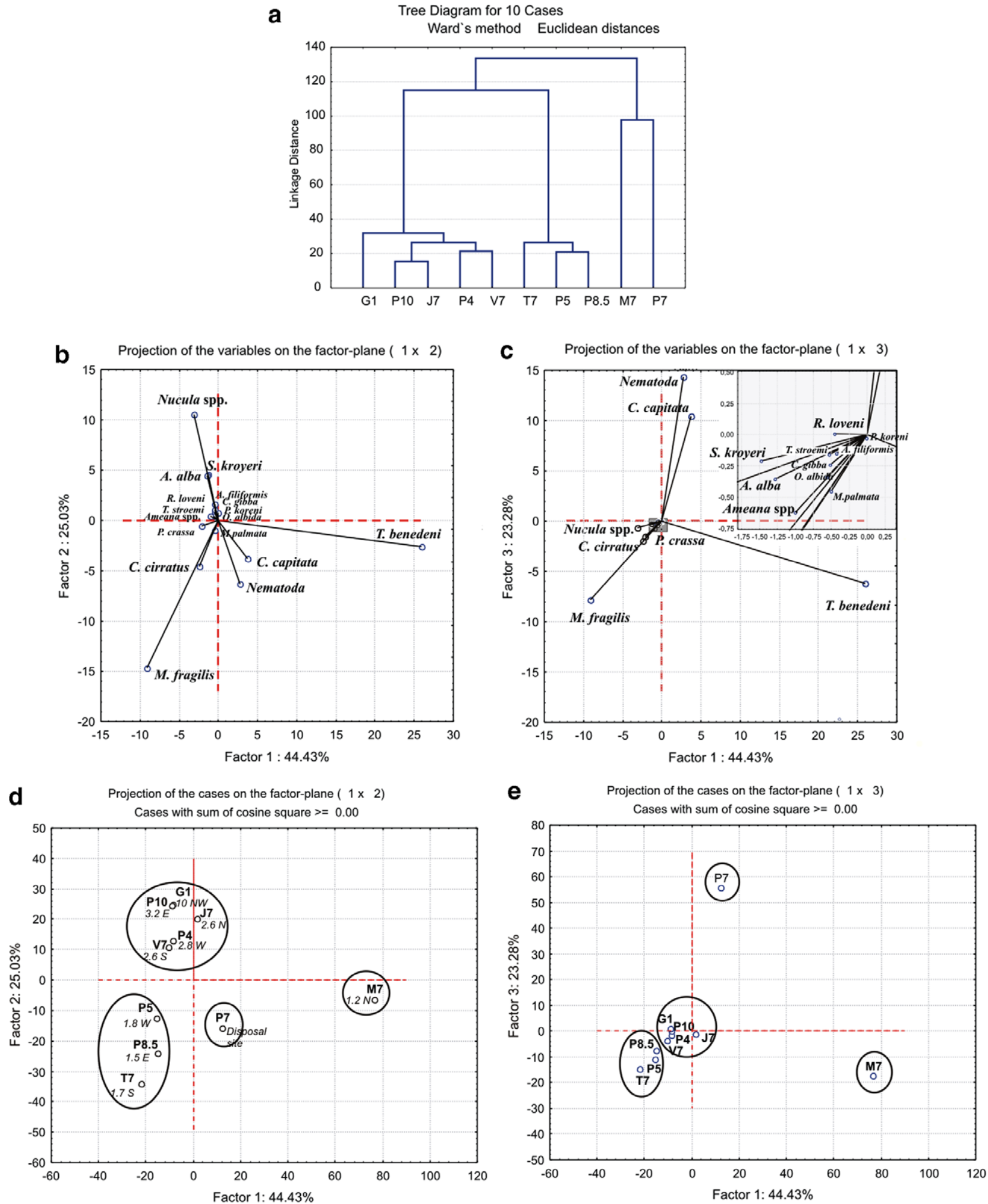

Fig. 16. PCA analysis. (a) Cluster according to Euclidean distances. (b) Projection of the variables (macrofauna) on the first two PCA axes. (c) Projection of the variables (macrofauna) on the factor-plane determined by PCA axes 1 and 3. (d) Plot of the 10 stations on the first two PCA axes, and four distinct assemblages (indicated by the dotted lines). (e) Plot of the 10 stations on the factor-plane determined by PCA axes 1 and 3.

Nordberg, 2001: depth $116 \mathrm{~m}$, temperature $5-8{ }^{\circ} \mathrm{C}$, salinity 34.4-34.8\%o). Alve and Murray (1999) found this species in shallow $(<6 \mathrm{~m})$ open waters around the Skagerrak and
Kattegat and they considered these occurrences as the northern limit of distribution for this species. Alve (1995a) found E. albiumbilicatum to be one of the most 


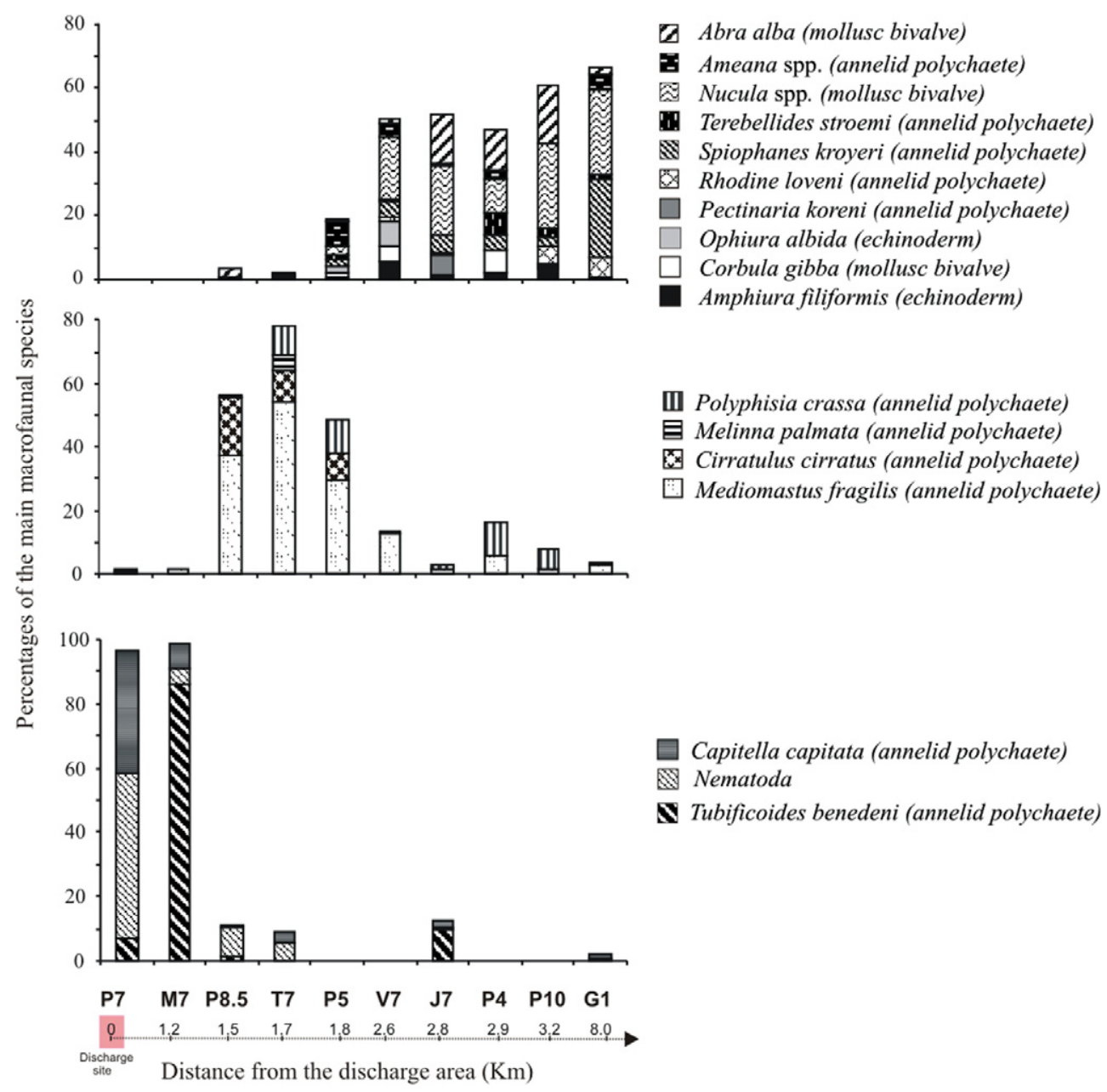

Fig. 17. Change in dominant species of benthic macrofauna $(>5 \%)$ following the distance from the discharge point.

eurythermal and euryhaline species in the Drammensfjord and Oslofjord.

Eggerella scabra is a continental shelf species (e.g. Murray, 1991; Barmawidjaja et al., 1992) that lives in various microhabitats from the oxygenated sediment surface to the deepest anoxic layers (e.g. Barmawidjaja et al., 1992; Jorissen et al., 1992; Ernst et al., 2002, 2005; Duijnstee et al., 2003, 2004). It appears therefore to be tolerant of strongly hypoxic conditions. For instance, E. scabra is common in the Adriatic Sea, in areas where large amounts of degraded organic matter cause oxygen depletion (Donnici and Serandrei-Barbero, 2002). E. scabra also occurs in estuarine areas (e.g. Murray, 1991), in association with Elphidium excavatum, where these species are also present in environments impacted by important anthropogenic discharges (e.g. Debenay et al., 1996). The related taxon Eggerella advena often co-occurs with E. scabra (e.g. Murray, 1991), but tends to occupy more superficial microhabitats (Barmawidjaja et al., 1992).

Nonionella turgida has been described as a continental shelf species that tolerates oxygen depletion fairly well (e.g. Jorissen, 1987; Barmawidjaja et al., 1995; Platon et al., 2005). In the northern Adriatic Sea, Duijnstee et al. (2004) observed that high relative abundances coincide with low oxygen index values and low bottom-water temperatures. On the basis of a laboratory experiment, Ernst et al. (2002) showed that in case of disturbed sediment, this species rapidly migrates to its preferred microhabitat at the sediment-water interface. These findings were confirmed in a more recent experimental study (Ernst et al., 2005) that showed rapid migration to the sediment surface and strongly declining standing stock in response to bottom water anoxia. In our study, $N$. turgida is only present in the stations farthest away from the dumpsite and in the reference station where a good bottom oxygenation is maintained.

It appears that several of the taxa, that are typical for the reference station G1 and the stations farthest away from the sewage disposal site, have been described in other areas as typical of slightly eutrophicated conditions. The fact that the taxa dominating the background studies are typical of enriched areas, suggests that the whole Garroch Head area is subject to the input of organic-rich sediments that create a naturally eutrophicated environment.

Zone 2 groups stations T7, $\mathrm{P} 4$ and $\mathrm{P} 5$, where high foraminiferal densities are recorded. The relative frequency of 


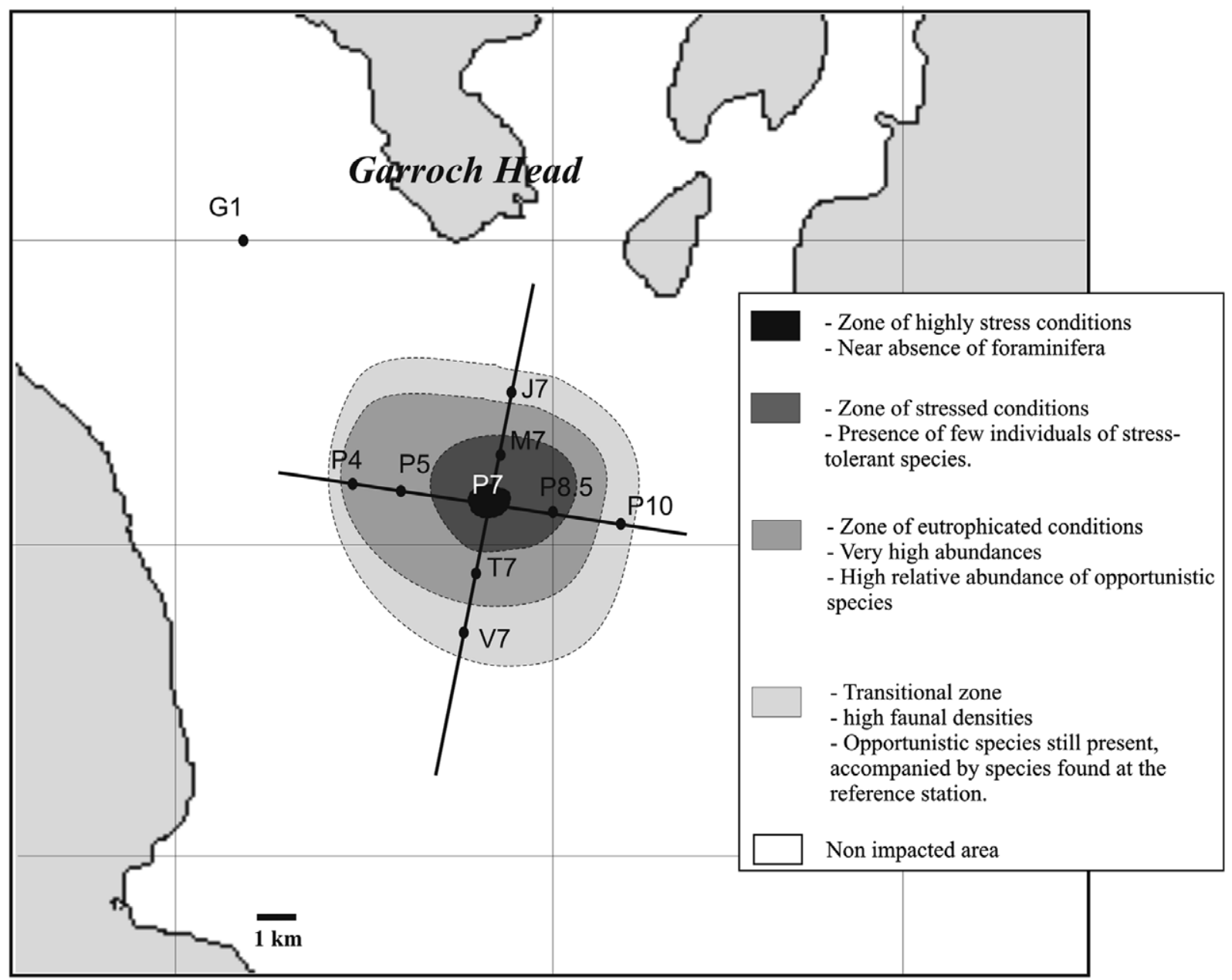

Fig. 18. Overview map, indicating the succession of foraminiferal zones with decreasing environmental impact at increasing distance from the sewage sludge disposal site.

Eggerella scabra decreases significantly and it is replaced by large numbers of opportunistic species (Bolivina seminuda, Bulimina marginata, Stainforthia concava) found in relatively low proportions in zone 1 . These species are accompanied by Reophax nana, Reophax nodulosus, Epistominella vitrea and Textularia spp., which will become much more important in zone 3.

Bolivina seminuda is a characteristic epifaunal or shallow infaunal taxon typical of eutrophic continental shelf environments (Barmawidjaja, 1991; Barmawidjaja et al., 1992; Duijnstee, 2001). Gooday et al. (2000) reported B. seminuda in the Arabian Sea oxygen minimum zone that is characterised by important (and highly seasonal) surface primary production, high organic carbon fluxes to the seafloor and high sediment TOC values and pigment concentrations. B. seminuda is a species that reacts to high nutrient availability with rapid reproduction (Langezaal et al., 2006). Barmawidjaja et al. (1995) studied the changes in foraminiferal assemblages influenced by the supply of human-induced nutrients to the northern Adriatic Sea, and concluded that the increasing nutrient load and consequent stress led to the increase in relative abundance of a limited number of stress-tolerant taxa (B. seminuda, Hopkinsina pacifica and Stainforthia fusiformis). Also in the low oxygen settings $(0.02-0.5 \mathrm{ml} / \mathrm{l})$ of Santa Barbara Basin, B. seminuda is a common taxon (Bernhard et al., 1997). A number of recent studies (Alve and Bernhard, 1995; Barmawidjaja et al., 1995; Duijnstee, 2001; Ernst et al., 2002) have insisted on the opportunistic life strategy of this taxon. The opportunistic behaviour becomes evident after disturbances, such as high sedimentation event and or an important anthropogenic input of organic-rich material. $B$. seminuda is one of the most successful colonizers of such newly formed habitats (Alve and Bernhard, 1995).

Bulimina marginata is an infaunal continental shelf to slope taxon (e.g. Jorissen et al., 1998), that has often been considered as an indicator of high food availability (e.g. Lutze and Colbourn, 1984; Debenay and Redois, 1997). It has been reported in a wide range of highly productive areas (e.g. Lutze and Colbourn, 1984; Jorissen et al., 1998; De Rijk et al., 2000; Fontanier et al., 2002). For several continental shelf areas, it has been used as a marker of upwelling phenomena (Phleger and Soutar, 1973; Bremmer, 1983; Murray, 1995; Debenay and Redois, 1997; Li 
et al., 1999; Mendes et al., 2004; Szarek et al., 2006). Because of its occurrence in low oxygen settings (e.g. Lutze and Colbourn, 1984), many scientists consider it also as a good marker of low oxygen conditions. In a study of the impact of oil drill cutting discharges at the outer continental shelf off Congo, Mojtahid et al. (2006) showed that $B$. marginata tolerates the putative oxygen depletion at the discharge point, and shows an opportunistic response to anthropogenic enrichment. In a recent study in the Subantartic area south-east of New Zealand that receives large amounts of phytodetritus from Subtropical, Subantartic and Circumpolar surface water masses, Hayward et al. (2006) show that B. marginata dominates the benthic foraminiferal faunas, and shows a significant positive correlation with chlorophyll-a values and a negative correlation with bottom water oxygen concentrations.

In the northern Adriatic sea, Stainforthia concava belongs, together with Hopkinsina pacifica, Bolivina dilatata, Bolivina seminuda, Bolivina spathulata, Nonionella turgida, Bulimina marginata and Epistominella vitrea (determined as E. exigua), to the group of foraminiferal taxa that show a maximum density in the organic-rich clay-belt parallel to the Italian coast. $S$. concava apparently responds to the high food availability in this area by an opportunistic life strategy (Jorissen et al., 1992). The taxonomically close taxon Stainforthia fusiformis is also known as an opportunistic taxon and is typical of organically enriched inner continental shelf settings where it is sometimes extremely abundant (e.g. Alve, 1994; Gooday et al., 2000). In the Danish part of the Skagerrak, Alve and Murray (1997) found increased relative frequencies of Stainforthia spp. in response to high input of particulate organic matter. In the Drammensfjord, southern Norway, the genus Stainforthia is considered as the first and the most efficient colonizer of the reoxygenation of formerly anoxic areas (Alve, 1991 b; Alve, 1995b).

Zone 3 groups stations P8.5 and M7, where we find low foraminiferal densities. The previously mentioned opportunistic species almost disappear and agglutinated taxa (Eggerella scabra, Reophax nana, Textularia porrecta/sagittula) dominate the assemblages. They are accompanied by the small calcareous species Epistominella vitrea and by some specimens of B. marginata. In Frierfjord, southern Norway, well oxygenated conditions were present throughout the water column in the pre-industrial period. With the onset of industrial pollution, dysoxic and anoxic conditions became established and the fauna changed to agglutinated species and in the anoxic areas, there was an absence of fauna (Murray, 2006).

Eggerella scabra is also a dominant faunal element in zone 1; its worldwide distribution has been described before. Its occurrence in the more stressed zone 3 can probably be explained by its high tolerance to low oxygen conditions.

The genus Textularia has been found to be tolerant of oxygen deficiency during summer stratification in the Adriatic Sea in front of the Po delta (Van der Zwaan and
Jorissen, 1991). In a study of the impact of drill cutting disposal off Congo (Mojtahid et al., 2006), Textularia sagittula was described in the vicinity of the disposal site where bottom water oxygenation is probably low due to the degradation of large amounts of organic matter.

Epistominella vitrea has been described on the outer shelf of the Bay of Biscay, (Langezaal et al., 2006), where this shallow infaunal species responds with rapid reproduction to the deposit of spring phytodetritus bloom remains. In previous studies on the Louisiana inner continental shelf, in an area impacted by seasonal hypoxia due to Mississipi runoff, Blackwelder et al. (1996) and Platon et al. (2005), observed that $E$. vitrea tolerates progressive oxygen depletion fairly well, and conclude that this species can be used in this area as a tracer of an elevated sedimentation rate and seasonal hypoxia. Also in other basins, E. vitrea has been observed under severely oxygen-depleted conditions (see Bernhard and Sen Gupta, 1999, Table 12.2). Jorissen et al. (1992), as E. exigua and Duijnstee et al. (2004) describe high densities of E. vitrea and Eggerella spp. in the eutrophicated northern Adriatic Sea, coinciding with low oxygen index values and low bottom-water temperatures. It should be realised, however, that Epistominella vitrea is not always associated with hypoxia. It may also occur in normal, oxic settings, e.g. in the McMurdo area in the Southern Ocean (Ward et al., 1987). AlsoEpistominella exigua (a deep-water relative of $E$. vitrea) has been described as an extremely opportunistic taxon, capable of rapidly colonising freshly deposited phytodetritus (e.g. Gooday and Turley, 1990; Heinz et al., 2001, 2002; Fontanier et al., 2003; Ernst and Van Der Zwaan, 2004).

Zone 4 corresponds to the centre of the disposal site (station P7) that is characterised by the almost total absence of foraminifera. This may be due to various factors: the first one is the severe hypoxia occurring in this area as the result of a strong organic enrichment. Recent studies (Alve and Bernhard, 1995; Moodley et al., 1997; Jannik et al., 1998) show that anoxic conditions cause a direct effect on the majority of the foraminiferal species. The absence of some taxa in strict anoxia in bottom and interstitial waters is probably the result of reproductive inhibition in such environments. However, numerous taxa are capable of surviving prolonged periods of anoxia (Moodley et al., 1997; Ernst et al., 2005), and it has recently been shown (Risgaard-Petersen et al., 2006) that some foraminiferal taxa are, under such conditions, capable to shift to anaerobic metabolism, by reducing nitrates.

The second factor that may be responsible for the almost total absence of foraminifera at the dumping site is the low $\mathrm{pH}$ value recorded at the sediment/water interface. This low $\mathrm{pH}$ may cause the dissolution of calcareous tests, and possibly inhibit calcification in these environments. We think that the near-total disappearance of foraminifera in zone 4, and perhaps also the strong increase in the relative abundance of agglutinated taxa in zone 3, may be a response to the progressive decrease 
in $\mathrm{pH}$ at the sediment-water interface towards the disposal site. The $\mathrm{pH}$ of normal seawater ranges between 7.8 and 8.3. In estuarine environments subject to the input of acid freshwater, or to the accumulation of organic matter, either anthropogenic or natural, the $\mathrm{pH}$ is generally lower (Boltowskoy, 1965; Boltowskoy and Wright, 1976; Nagy and Johansen, 1991). For instance, Shafer (1970) recorded a $\mathrm{pH}$ value of 7.2 near an industrialized outfall. Alve and Nagy (1986) reported values below 7.0 on a mudflat close to a paper mill outlet. Both studies report a reduction of the relative frequency of calcareous foraminifera over time, with the recent faunas only containing arenaceous species. Boltowskoy and Wright (1976) indicated that calcareous foraminifera start to dissolve at $\mathrm{pH}$ values of less than 7.8. However, these authors do not indicate whether living or dead specimens have been considered. It is probable that living specimens are less easily attacked due to the presence of a "protective" cytoplasm. Le Cadre et al. (2003) observed, in a laboratory study of the effects of $\mathrm{pH}$ on the calcification of the hyaline species Ammonia beccarii, that the decalcification of the tests of living specimens started when the $\mathrm{pH}$ fell below 7.5 .

A last factor that may contribute to the strongly adverse conditions at the disposal site is the eventual presence of sulphidic substances close to the sediment-water interface. In environments impacted by important organic matter input, the destruction of organic matter by microbial activity may cause anoxic and sulphidic conditions, due to the formation of ferrous sulphide minerals, close to the sediment water interface. When these ferrous sulphides are oxidized, a decrease of the $\mathrm{pH}$ is the result, which may cause carbonate dissolution (Reaves, 1986). In a classical foraminiferal study, Bandy et al. (1964) reported a 'dead zone' around a Californian outfall area, where the sediment was black due to the presence of sulphides. However, it is not evident that the absence of foraminifera at this site is exclusively caused by the presence of sulphides.

Summarizing, the foraminiferal distribution presents a typical picture, with (1) azoic conditions at the disposal site and (2) strongly impoverished faunas composed exclusively of species tolerant to important oxygen depletion closest to the disposal site. This strongly impacted area is surrounded by an aureole of high density faunas with large numbers of opportunistic species, gradually changing into a dominance of a small number of more stable taxa at the outer ends of the transects (Fig. 18). At about $3 \mathrm{~km}$ of the disposal site, faunas are more or less comparable to those found at reference station G1.

\subsection{Macrofaunal response to sewage sludge disposal}

The successional changes in faunal composition along the increasing gradient of organic enrichment towards the centre of the disposal site closely follow the ideal pattern of such successions (Pearson and Rosenberg, 1978). Chandler (1970), Washington (1984) and Hellawell (1986) suggest that sensitive species progressively decrease in numbers when the water quality deteriorates and are replaced by more tolerant taxa, which are rare or absent at unimpacted sites. In our study, we clearly observe such a succession, both along our N/S and W/E transects. The faunal distribution varies in response to an organic enrichment gradient, as described by Pearson and Rosenberg (1978). The density and composition of the faunas allow us to subdivide the studied area into three distinct zones. Although the foraminiferal and macrofaunal zonations are very similar, they are not comparable. In case of foraminifera, four assemblages and biofacial zones were recognized whereas in the case of macrofauna, only 3 assemblages can be distinguished.

Zone 1 contains stations located between 2 and $3 \mathrm{~km}$ from the disposal site (V7, J7, P4 and P10). These four stations are characterized by intermediate biomass (from 12 to $46 \mathrm{~g}$ wet weight $/ 0.1 \mathrm{~m}^{2}$ ) abundance (between 120 and 430 individuals $/ 0.1 \mathrm{~m}^{2}$ ) and species richness (between 37 and 64 species). The faunas of this zone are characterised by important proportions of Amphiura filiformis, Corbula gibba, Ophiura albida, Pectinaria koreni, Rhodine loveni, Spiophanes kroyeri, Terebellides stroemi, Nucula spp., Ameana spp. and Abra alba. The majority of these taxa are also typical for the macrobenthic community in the supposedly unimpacted control area, $8 \mathrm{~km} \mathrm{NW}$ of the disposal site. These species are in general large animals with a slow turnover rate (K-strategy) that live in stable, well-oxygenated environments. They are accompanied by low numbers of species with a more opportunistic life style (A. alba and C. gibba), that occur in much higher percentage in zone 2 .

A study of Nilsson (1999) on the effects of hypoxia and organic enrichment demonstrated that the burrowing brittle star Amphiura filiformis is very sensitive to hypoxia. Experimental studies have shown reduced growth rates of A. filiformis in oxygen concentrations below $2.7 \mathrm{mg} \mathrm{O} / 2$. At $1.2 \mathrm{mg} \mathrm{O} / 1$, the species initiates an escape response from its burrow in the sediment. Below oxygen concentrations of $0.5 \mathrm{mg} \mathrm{O} / 1$, its mortality increases (Rosenberg et al., 1991; Nilsson and Rosenberg, 1994; Nilsson and Sköld, 1996; Vistisen and Vismann, 1997). A high abundance and biomass of A. filiformis and Amphiura chiajei has been observed at well ventilated sites in the Skagerrak (Josefson, 1990). In the same areas, severe hypoxic events $(<0.7 \mathrm{mg} \mathrm{O} / 2 / 1)$ led to a mass mortality of $A$. filiformis (Rosenberg and Loo, 1988).

The spionid polychaete Spiophanes kroyeri and its congener Spiophanes missionensis decline toward sewage outfall areas (Aschan and Skullerud, 1990; Maurer et al., 1998, respectively). Also Spiophanes bombyx has a low tolerance to seasonal oxygen depletion (Niermann et al., 1990). Conlan et al. (2004) studied the benthic changes during 10 years of organic enrichment due to sewage and hydrocarbon disposal off Antarctica. They observed high abundances of Spiophanes tcherniae at supposedly unimpacted reference stations. Apparently, this species does 
not tolerate high organic enrichment levels (Lenihan et al., 2003).

Nucula turgida is a small bivalve that is common in shallow water assemblages along the French Cotentin coast in areas with well-oxygenated waters and fine-grained sediments (Dauvin et al., 2004).

In addition to these taxa, that are generally considered to have a low tolerance to organic pollution, we find also in this area some species ( $A$. alba and Corbula gibba) that are near absent at the reference station (G1) and are in the literature considered as more opportunistic (Dauvin, 1984, 2000; Simonini et al., 2004).

The A. alba community forms a well-established faunal unit in coastal areas of the North Sea (Dewarumez et al., 1986; Van Hoey et al., 2005), where it is mostly found in bays, estuaries and in a narrow zone along the coast. It appears to be positively affected by the input of terrestrial organic matter input (Sanvicente-Anorve et al., 2002). $A$. alba is considered as an opportunistic species, comparable to Melinna palmata and Pectinaria koreni that also show rapid growth in the presence of important food inputs (Dauvin, 1984, 2000).

The bivalve Corbula gibba is often considered as an indicator of sediment instability (Perés and Picard, 1964) and organic enrichment (Diaz and Rosenberg, 1995). This species dominates the macrofaunal community in the

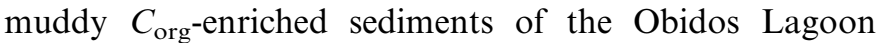
(Portugal) (Carvalho et al., 2005). Also coastal stations in the northern Adriatic Sea with muddy sediments are characterized by a high abundance of the opportunistic bivalve C.gibba, that appears to be typical of unstable areas with a high sedimentation rate (Simonini et al., 2004). It is also widely distributed in estuaries in northern Europe and in the Mediterranean Sea and is one of the most resistant species with respect to severe hypoxia. It is therefore often abundant in eutrophicated areas (Christensen, 1970; Pearson and Rosenberg, 1978; Diaz and Rosenberg, 1995).

Zone 2 contains stations located $1.5-2 \mathrm{~km}$ from the disposal site (P8.5, T7 and P5). The faunas of these three stations are characterized by high biomasses (varying from 12 to $40 \mathrm{~g}$ wet weight $/ 0.1 \mathrm{~m}^{2}$, high abundances (between 660 and 2240 individuals $/ 0.1 \mathrm{~m}^{2}$ ) and a high species richness (between 53 and 72 species). In zone 2, the taxa typical of zone 1 progressively disappear and are replaced by the more opportunistic species Mediomastus fragilis and Cirratulus cirratus, that are accompanied by Melinna palmata and Polyphisia crassa.

In a study of the impact of the Amoco Cadiz oil spill on benthic organisms in the Bay of Morlaix (Dauvin, 1984; Dauvin, 2000), only two small opportunistic subsurface deposit feeding polychaetes (Mediomastus fragilis and Tharyx marioni) increased their abundance just after the oil spill, probably as a response to an increase in organic matter. Levin et al. (2006) studied the influence of sulphide on the benthic faunal recruitment and survival and observed that the polychaete Mediomastus sp. belongs to a community that exhibits significantly higher densities in sulfidic sediments. In the Rhône delta, Mediomastus sp. exhibits a high growth rate and an ability to adapt its reproductive behaviour in order to rapidly exploit inputs of organic matter after flood events (Salen-Picard et al., 2003).This polychaete had also been described in large numbers in polluted environments or following phytoplankton bloom events (Pearson and Rosenberg, 1978; Blake, 1993; Bachelet and Laubier, 1994).

Cirratulus cirratus is a predominantly intertidal polychaete. It can appear in large numbers in areas with high concentrations of organic waste. It usually lives buried in mud or sand or under rocks. It is common along the entire Norwegian coast (Neal and Ballerstedt, 2006). This species has been described as an opportunistic deposit feeder characteristic of areas of organic enrichment (Penry and Jumars, 1990).

Melinna palmata is not considered as an opportunistic taxon in the literature. It belongs to a community that is common in rias and estuaries of Brittany where hydrodynamic energy is low, allowing the sedimentation of large amounts of fine-grained sediments rich in organic matter (Dauvin, 1984, 2000).

Zone 3 groups stations $\mathrm{P} 7$ and $\mathrm{M} 7$. At these stations, the species typical of zone 2 entirely disappear and only populations of annelids (Capitella capitata, Tubificoides benedeni) and nematode worms are present. Station M7, $1.2 \mathrm{~km}$ north of the disposal site, is characterised by a faunal density one to two orders of magnitude higher than at all other sites, and a very strong dominance of $T$. beneden$i$. The fauna at station $\mathrm{P} 7$, on the contrary, has a relatively low density, and is dominated by $C$. capitata and by nematodes.

The cosmopolitan polychaete Capitella capitata is a non-selective subsurface deposit feeder (Fauchald and Jumars, 1979) that is often associated with polluted environments, and has been widely used as a bio-indicator of organic pollution (Warren, 1976; Tsutsumi, 1990; Méndez et al., 1997). Field studies on the population dynamics of C. capitata have found early colonization of azoic areas, followed by rapid population increase, and finally, by a subsequent rapid decline (Grassle and Grassle, 1974; Rosenberg, 1976; McCall, 1977; Pearson and Rosenberg, 1978; Kikuchi, 1979; Gray, 1981; Tsutsumi and Kikuchi, 1984).

The oligochaete Tubificoides benedeni is known in the literature to live in stressed habitats characterized by high levels of hydrogen sulphide, such as eutrophic tidal flats and polluted coastal sites. It has a high capacity to tolerate anoxic (and sulfidic) conditions. Earlier physiological studies (Giere et al., 1988; Dubilier et al., 1994, 1995, 1997) suggest the presence of adaptive strategies (a highly specialized physiology combined with supplementary behavioural and structural adaptations) that make $T$. benedeni one of the most successful inhabitants of ecologically stressed, sulfidic benthic environments. Giere 
et al. (1999), who measured respiration rates of $T$. benedeni at various oxygen concentrations, show that aerobic respiration is maintained even at very low oxygen concentrations. This ability to continue aerobic respiration is combined with a high regulatory capacity of oxygen uptake. This study is corroborated by the comparison with other typical'sulphide annelids' such as the polychaetes $C$. capitata, that use very similar ecological strategies to survive in these hostile environments.

In many studies, nematodes occur in areas enriched in heavy metals and organic pollutants (Fenske and Günther, 2001; Szymelfenig et al., 2006). Neira et al. (2001) observe high nematode abundances at oxygen concentrations below $0.02 \mathrm{ml} / 1$. The high densities are probably an indirect effect of low oxygen causing a strong reduction of predators and competitors and the preservation of organic matter leading to an abundance of high quality food. Free-living nematodes are an important component of marine suboxic, anoxic and sulphidic benthic habitats (Moodley et al., 1997; Modig and Ólafsson, 1998). Sul- phidic habitats occur whenever an excess of organic material leads to exhaustion of the available electron acceptors $\mathrm{O}_{2}$, nitrate, iron oxides and manganese oxides by bacterial respiration. In these environments, not only oxygen is lacking, but the resident higher organisms have to avoid the toxic effects of hydrogen sulphide. Physiological adaptations allowing the organism to do so are: (1) switching to an anaerobic metabolism, (2) excluding sulphide from sensitive tissues, and (3) oxidizing sulphide to more benign forms (Somero et al., 1989; Steyaert et al., 2007).

Summarizing, also our macrofaunal data present a typical picture, with strongly impoverished faunas composed exclusively of species tolerant to important oxygen depletion closest to the disposal site. This area is surrounded by an aureole of high density faunas with important opportunistic mainly small-sized species gradually changing into a dominance of a small number of larger sized equilibrium species at the outer ends of the transects (Fig. 19).

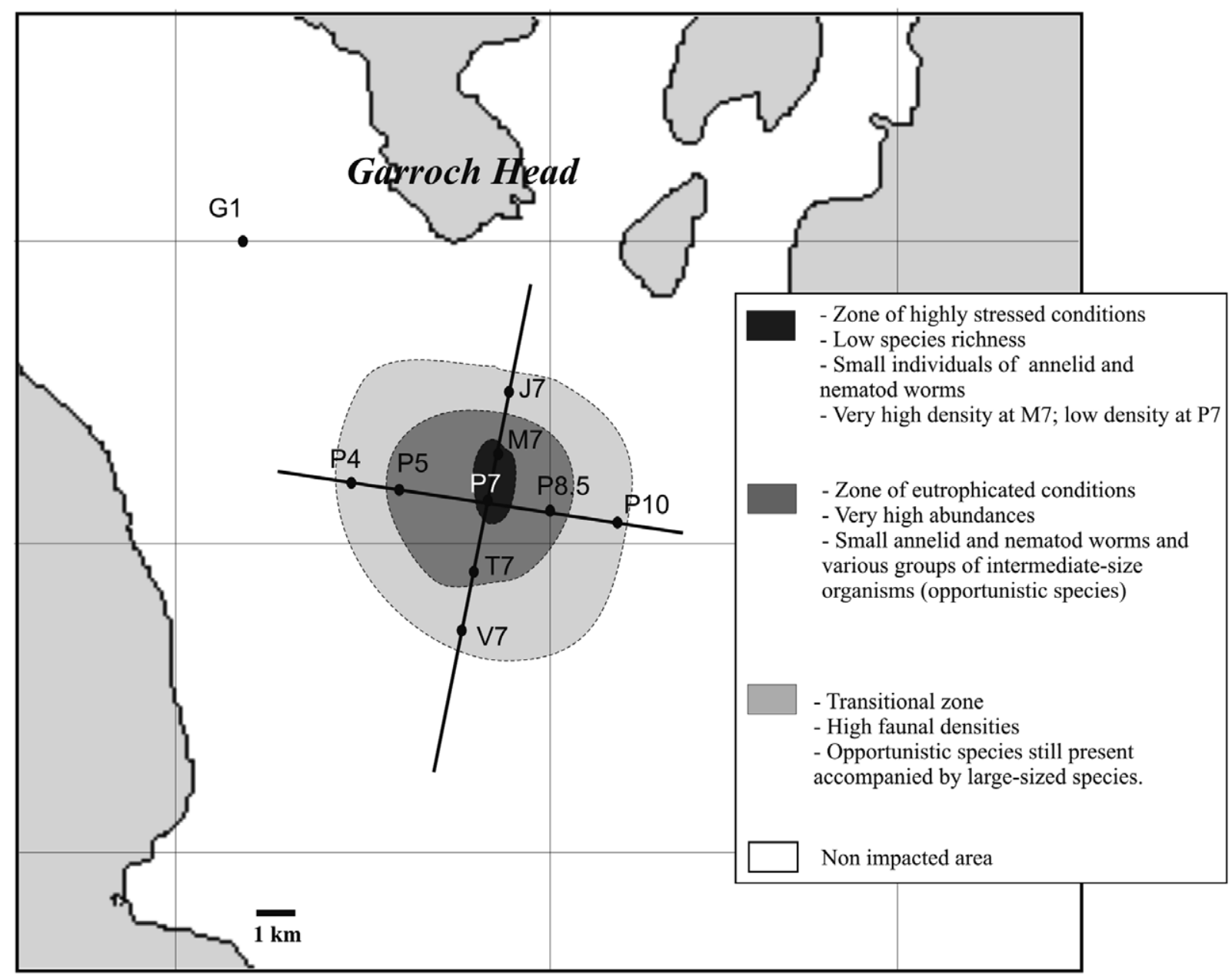

Fig. 19. Overview map, indicating the succession of macrofaunal zones with decreasing environmental impact at increasing distance from the sewage sludge disposal site. 


\subsection{Comparison of foraminiferal and macrofaunal bio- indicators of ecosystem eutrophication}

In order to better represent the faunal differences between the impacted stations, we developed an index based on the cumulative percentages of species indicative of stress and of anthropogenic eutrophication, related to the sewage sludge disposal. Because of their distributional patterns in the study area, we selected the foraminiferal taxa Textularia porrecta, Textularia sagittula, Reophax nana, Eggerella scabra, Bolivina seminuda, Reophax nodulosus, Bulimina marginata, Stainforthia concava and Epistominella vitrea as bio-indicators of organic enrichment. The macrofaunal bio-indicators we selected are Tubificoides benedeni, Nematoda, Capitella capitata, Mediomastus fragilis, Cirratulus cirratus, Melinna palmata, Polyphisia crassa, Abra alba, Corbula gibba and Rhodine loveni.

In Fig. 20, for both groups, foraminifera and macrofauna, the cumulative percentage of these index taxa is plotted as a function of the distance to the disposal site. It can be seen that foraminifera and macrofauna show a very similar response to sewage disposal, with stress-tolerant species dominating in the area close to the disposal site, and less tolerant taxa become progressively more important at a greater distance from the disposal site.

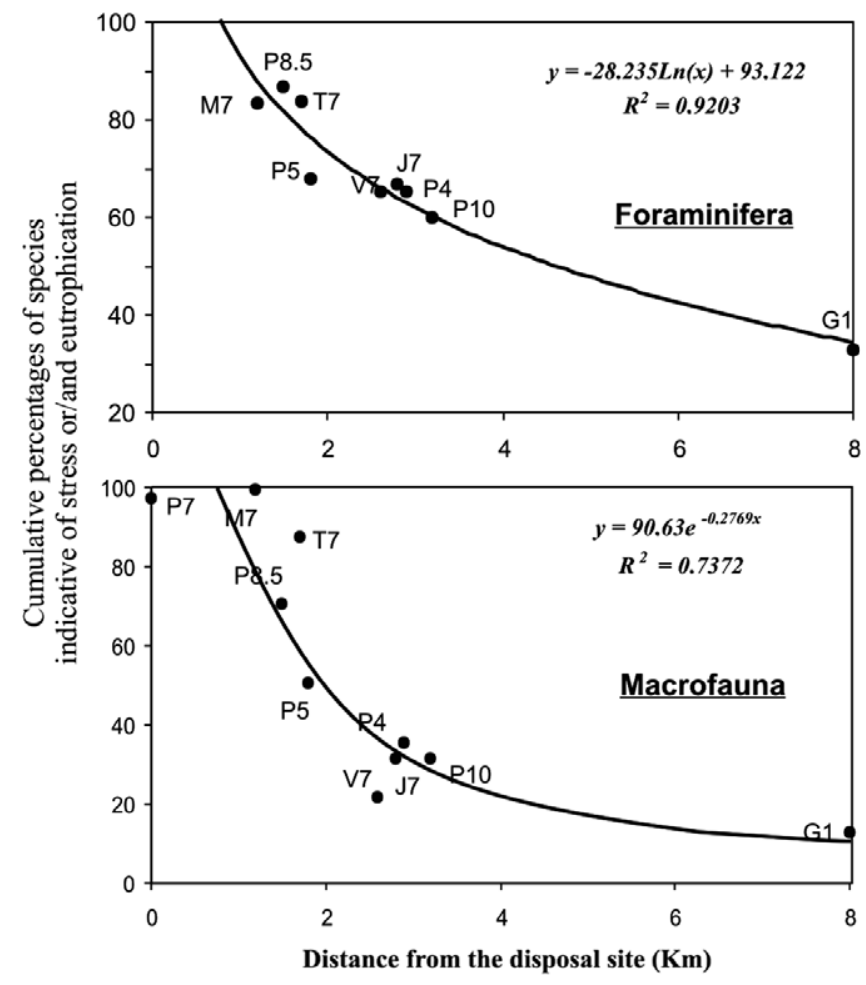

Fig. 20. Cumulative percentages of all taxa indicative of natural and/or anthropogenic eutrophication and ecosystem stress, in function of distance to the drill cutting disposal.
When comparing the foraminiferal and macrofaunal patterns in more detail, some important differences can nevertheless be observed:

(1) At the disposal site (station P7), foraminifera are totally absent whereas some nematode and annelid worms are present. This difference may be due to the low $\mathrm{pH}$ recorded in this area that could inhibit the calcification of the tests of calcareous taxa, which are more resistant to stressed conditions than agglutinated taxa.

(2) At station M7, the extremely rich macrofauna, dominated by the polychaete Tubificoides benedeni contrasts with the very poor foraminiferal fauna, consisting mainly of agglutinated taxa. Again, this difference may be due to the sensitivity of the calcareous taxa to a low $\mathrm{pH}$.

(3) The foraminiferal composition at stations P7 and M7 suggests strongly stressed conditions in this area, whereas the composition and high density of the macrofauna indicate strongly eutrophicated conditions, without physical stress for the dominant taxa. Furthermore, the foraminiferal faunas at station P4 are indicative of eutrophicated conditions, whereas the macrofaunal community structure, that is similar to that observed at the reference station, is indicative of a transitional ecosystem. We conclude that foraminifera are more sensitive to this particular type of environmental stress than macrofauna and suffer a more important impact by sewage sludge. Since foraminifera are particularly tolerant to organic enrichment and oxygen depletion in many other areas, we assume that their lower tolerance in the Garroch Head area is caused by the low $\mathrm{pH}$ of the sewage effluents.

\section{Conclusions}

We used an ecological approach using benthic foraminifera and macrofauna to investigate the impact of sewage sludge discharge in the Firth of Clyde. The comparison of both faunal groups, complemented by physico-chemical analyses of sediment and bottom-waters, allows an adequate description of the health of the surrounding marine environment.

Sedimentary organic carbon and nitrogen contents are very high in the vicinity of the disposal site and decrease progressively further away. Low redox values in the vicinity of the disposal site, at the sediment surface as well as within the topmost sediment, are indicative of highly reducing conditions brought about by the degradation of large amounts of organic material. Also metals concentration show maximum values close to the discharge point.

The faunal analysis shows for both analysed bio-marker groups (macrofauna and foraminifera) a comparable 
ecological succession that is typical for strongly eutrophicated areas:

(1) a zone of severely stressed conditions in the immediate vicinity of the disposal grounds where abundances and biodiversity are very low and where the faunas contain only a few species that are tolerant to strong oxygen depletion,

(2) a second zone contains a fauna typical of enriched conditions, characterised by a high faunal density and a strong dominance of a limited number of opportunistic species,

(3) a third zone appears to present a transitional situation, where the environmental impact is minimal, but still perceptible. Faunal densities are still elevated and the faunal composition shows a slightly elevated percentage of opportunistic taxa in comparison to the unpolluted reference station. These opportunistic taxa are accompanied by equilibrium taxa typical of unimpacted environments.

When the two groups of bio-indicators, foraminifera and macrofauna are compared in more detail, some important differences show up, which suggest that foraminifera are more sensitive to this specific type of environmental disturbance than macrofauna. Environmental impact is still perceptible in the foraminiferal faunas at relatively low levels, where macrofauna apparently is no longer affected. This makes foraminifera particularly useful for this type of environmental survey. We think that the higher sensitivity of foraminifera is caused by the consistently low $\mathrm{pH}$ values in the upper sediment layers, that especially appear to affect species provided with calcareous tests, that in other areas are most resistant to dysoxic conditions. These calcareous taxa may have serious problems to calcify in the acidic sedimentary environments around the disposal site.

Appendix A. Results of acidity and redox potential measurements in the sediment

\begin{tabular}{lllllllllllllllllllllll}
\hline Station & G1 & & J7 & & M7 & & P7 & & T7 & & V7 & & P4 & & P5 & & P8.5 & P10 \\
\hline Depth $(\mathrm{m})$ & 87 & & 79 & & 73 & & 79 & & 119 & & 178 & & 154 & & 135 & & 58 & & 75 & \\
\hline Level $(\mathrm{cm})$ & $\mathrm{pH}$ & Eh & $\mathrm{pH}$ & $\mathrm{Eh}$ & $\mathrm{pH}$ & $\mathrm{Eh}$ & $\mathrm{pH}$ & $\mathrm{Eh}$ & $\mathrm{pH}$ & $\mathrm{Eh}$ & $\mathrm{pH}$ & $\mathrm{Eh}$ & $\mathrm{pH}$ & $\mathrm{Eh}$ & $\mathrm{pH}$ & Eh & $\mathrm{pH}$ & Eh & $\mathrm{pH}$ & Eh \\
\hline 1.0 & 8.02 & 442 & 7.99 & 417 & 7.98 & 311 & 7.9 & 180 & 7.92 & 451 & 7.89 & 452 & 7.87 & 468 & 8.06 & 435 & 7.95 & 454 & 7.94 & 417 \\
0.0 & 7.76 & 448 & 7.51 & 378 & 7.63 & 189 & 7.26 & -96 & 7.52 & 107 & 7.77 & 454 & 7.48 & 498 & 7.71 & 355 & 7.54 & 273 & 7.46 & 439 \\
-0.5 & 7.74 & 446 & 7.49 & 352 & 7.57 & 152 & 7.22 & -105 & 7.32 & 57 & 7.63 & 453 & 7.54 & 486 & 7.59 & 280 & 7.45 & 154 & 7.41 & 402 \\
-1.0 & 7.69 & 428 & 7.48 & 335 & 7.54 & 104 & 7.2 & -124 & 7.36 & 53 & 7.56 & 451 & 7.62 & 475 & 7.56 & 223 & 7.46 & 133 & 7.4 & 369 \\
-1.5 & 7.65 & 367 & 7.48 & 334 & 7.52 & 82 & 7.2 & -127 & 7.33 & 53 & 7.62 & 446 & 7.76 & 468 & 7.57 & 136 & 7.47 & 123 & 7.41 & 301 \\
-2.0 & 7.66 & 271 & 7.48 & 301 & 7.49 & 40 & 7.22 & -133 & 7.31 & 51 & 7.72 & 435 & 7.84 & 456 & 7.6 & 127 & 7.49 & 105 & 7.42 & 268 \\
-2.5 & 7.64 & 188 & 7.47 & 282 & 4.47 & 36 & 7.23 & -141 & 7.32 & 36 & 7.77 & 426 & 7.91 & 448 & 7.64 & 115 & 7.51 & 101 & 7.44 & 258 \\
-3.0 & 7.61 & 131 & 7.46 & 226 & 7.44 & 28 & 7.24 & -143 & 7.34 & 34 & 7.81 & 421 & 7.99 & 445 & 7.72 & 99 & 7.54 & 81 & 7.47 & 212 \\
-3.5 & 7.67 & 114 & 7.46 & 197 & 7.4 & 18 & 7.23 & -145 & 7.35 & 33 & 7.83 & 416 & 8.03 & 443 & 7.77 & 93 & 7.58 & 82 & 7.54 & 184 \\
-4.0 & 7.71 & 108 & 7.46 & 176 & 7.35 & 5 & 7.23 & -153 & 7.36 & 30 & 7.84 & 364 & 8.04 & 440 & 7.8 & 87 & 7.6 & 58 & 7.61 & 169 \\
-4.5 & 7.73 & 98 & 7.47 & 170 & 7.31 & -6 & 7.22 & -157 & 7.37 & 30 & 6.86 & 290 & 8.05 & 416 & 7.81 & 83 & 7.6 & 48 & 7.65 & 142 \\
-5.0 & 7.73 & 91 & 7.49 & 152 & 7.3 & -9 & 7.21 & -158 & 7.38 & 26 & 6.86 & 257 & 8.05 & 336 & 7.79 & 79 & 7.58 & 41 & 7.64 & 141 \\
-7.5 & 7.73 & 84 & 7.57 & 97 & 7.19 & -35 & 7.22 & -167 & 7.4 & 24 & 7.76 & 191 & 7.6 & 258 & 7.75 & 78 & 7.47 & 30 & 7.56 & 131 \\
-10.0 & 7.74 & 87 & 7.52 & 85 & & -50 & 7.26 & -172 & 7.44 & 16 & 7.63 & 168 & 7.43 & 191 & 7.65 & 14 & 7.55 & 5 & 7.57 & 129 \\
\hline
\end{tabular}

Appendix B. Results of organic carbon and nitrogen measurements

\begin{tabular}{lllllllllll}
\hline Station & $\mathrm{G} 1$ & $\mathrm{~J} 7$ & $\mathrm{M} 7$ & $\mathrm{P} 7$ & $\mathrm{~T} 7$ & $\mathrm{~V} 7$ & $\mathrm{P} 4$ & $\mathrm{P} 5$ & $\mathrm{P} 8.5$ & P10 \\
\hline Water depth $(\mathrm{m})$ & 87 & 79 & 73 & 79 & 119 & 178 & 154 & 135 & 58 & 75 \\
\hline Distance from the diposal site $(\mathrm{km})$ & $8 \mathrm{NW}$ & $2.8 \mathrm{~N}$ & $1.2 \mathrm{~N}$ & 0 & $1.7 \mathrm{~S}$ & $2.6 \mathrm{~S}$ & $2.9 \mathrm{~W}$ & $1.8 \mathrm{~W}$ & $1.5 \mathrm{E}$ & $3.2 \mathrm{E}$ \\
\hline $\mathrm{C}(\%$ d.w) & 2.6 & 1.9 & 2.2 & 12.4 & 4.4 & 2.5 & 2.6 & 3.2 & 5.6 & 2.2 \\
$\mathrm{~N}(\%$ d.w $)$ & 0.26 & 0.16 & 0.22 & 1.26 & 0.49 & 0.28 & 0.28 & 0.32 & 0.58 & 0.21 \\
$\mathrm{C} / \mathrm{N}$ & 10.0 & 11.9 & 10.0 & 9.8 & 9.0 & 8.9 & 9.3 & 10.0 & 9.7 & 10.5 \\
\hline
\end{tabular}




\section{Appendix C. Results of metal concentrations in the surficial sediment}

\begin{tabular}{|c|c|c|c|c|c|c|c|c|c|c|c|c|c|}
\hline \multirow[t]{2}{*}{ Sample } & \multirow[t]{2}{*}{ Sample size $(\mathrm{g})$} & \multirow[t]{2}{*}{ Wt. of sed. (g) } & \multicolumn{11}{|c|}{ Metals (mg/kg dry solids) } \\
\hline & & & $\mathrm{Cd}$ & $\mathrm{Cr}$ & $\mathrm{Cu}$ & $\mathrm{Hg}$ & $\mathrm{Ni}$ & $\mathrm{Pb}$ & $\mathrm{Zn}$ & As & $\mathrm{Co}$ & $\mathrm{Fe}$ & $\mathrm{Mn}$ \\
\hline G1 & 14 & 1 & $<0.5$ & 94 & 40 & 0.4 & 45 & 96 & 202 & 14 & 16 & 0.0369 & 1770 \\
\hline $\mathrm{J} 7$ & 25.9 & 1 & 0.5 & 105 & 150 & 0.5 & 41 & 84 & 175 & 11 & 12 & 0.0242 & 380 \\
\hline M7 & 21.5 & 1 & 2.5 & 308 & 258 & 0.9 & 42 & 146 & 379 & 24 & 12 & 0.0258 & 283 \\
\hline P7 & 8.3 & 1 & 7.0 & 634 & 433 & 1.5 & 43 & 302 & 723 & 52 & 10 & 0.0228 & 212 \\
\hline $\mathrm{T} 7$ & 18.3 & 1 & 1.0 & 195 & 125 & 0.5 & 44 & 110 & 270 & 15 & 14 & 0.033 & 385 \\
\hline V7 & 14.1 & 1 & $<0.5$ & 92 & 125 & 0.3 & 44 & 76 & 190 & 13 & 16 & 0.036 & 1550 \\
\hline P4 & 13.2 & 1 & $<0.5$ & 99 & 86 & 0.3 & 43 & 88 & 215 & 11 & 17 & 0.0365 & 2400 \\
\hline P5 & 16.0 & 1 & 0.5 & 134 & 94 & 0.3 & 46 & 104 & 238 & 14 & 16 & 0.0366 & 723 \\
\hline P8.5 & 29.0 & 1 & 2.0 & 195 & 140 & 0.6 & 31 & 120 & 260 & 19 & 9 & 0.022 & 220 \\
\hline P10 & 30.0 & 1 & $<0.5$ & 86 & 44 & 0.3 & 42 & 70 & 152 & 10 & 14 & 0.0308 & 419 \\
\hline
\end{tabular}

Appendix D. Census data and percentages of macrofauna in the topmost centimetre of a $0.1 \mathrm{~m}^{2} \mathrm{samples}$

\begin{tabular}{|c|c|c|c|c|c|c|c|c|c|c|c|c|c|c|c|c|c|c|c|c|}
\hline Distance $(\mathrm{km})$ & 8.0 & & 2.8 & & 1.2 & & 0.0 & & 1.7 & & 2.6 & & 2.9 & & 1.8 & & 1.5 & & 3.2 & \\
\hline Species & G1 & $\%$ & $\mathrm{~J} 7$ & $\%$ & M7 & $\%$ & P7 & $\%$ & $\mathrm{~T} 7$ & $\%$ & V7 & $\%$ & $\mathrm{P} 4$ & $\%$ & P5 & $\%$ & P8.5 & $\%$ & $\mathrm{P} 10$ & $\%$ \\
\hline Abra alba (mollusca) & 1 & 1.7 & 65 & 15.0 & & & & & 4 & 0.2 & 4 & 1.8 & 15 & 12.7 & 4 & 0.5 & 26 & 2.7 & 28 & 17.5 \\
\hline Abra nitida (mollusca) & & & 2 & 0.3 & & & & & & & & & & & 1 & 0.1 & & & & \\
\hline Abra sp.indet. (mollusca) & & & & & & & & & & & & & & & 15 & 2.3 & & & & \\
\hline Ameana trilobata (polychaeta) & 3 & 5.2 & 4 & 0.9 & & & & & & & 3 & 1.3 & 4 & 3.0 & & & & & & \\
\hline AmeanalPolycirrus (polychaeta) & & & & & & & & & 17 & 0.7 & 6 & 2.4 & & & 53 & 8.0 & 3 & 0.3 & & \\
\hline Ampharete baltica (polychaeta) & & & & & & & & & & & & & & & & & 21 & 2.3 & & \\
\hline Ampharete finmarchia (polychaeta) & & & & & & & & & 21 & 0.9 & & & 1 & 0.4 & 10 & 1.4 & 4 & 0.4 & 1 & 0.6 \\
\hline Ampharete sp.indet. (polychaeta) & & & 6 & 1.4 & & & & & 3 & 0.1 & & & 1 & 0.4 & 1 & 0.1 & 4 & 0.4 & & \\
\hline Amphicteis gracilis (polychaeta) & & & & & & & & & & & & & & & 2 & 0.2 & 1 & 0.1 & 3 & 1.6 \\
\hline Amphicteis gunneri (polychaeta) & & & & & & & & & & & & & & & & & & & & \\
\hline Amphipodasp. indet. (Crsutacea, Amphipoda) & 1 & 0.9 & 2 & 0.5 & 2 & 0.0 & & & & & 1 & 0.2 & & & 3 & 0.4 & 7 & 0.7 & & \\
\hline Amphitrite cirrata (polychaeta) & & & & & & & & & & & & & & & 1 & 0.2 & & & & \\
\hline Amphiura chiajei (Echinodermata) & 2 & 2.6 & & & & & & & & & 1 & 0.4 & 3 & 2.1 & & & & & 4 & 2.5 \\
\hline Amphiura filiformis (Echinodermata) & & & 2 & 0.3 & & & & & & & 12 & 5.3 & 3 & 2.1 & 3 & 0.5 & & & 5 & 3.2 \\
\hline
\end{tabular}


Arctica islandica (mollusca)

Brissopsis lyrifera (Echinodermata)

Calocaris macandeae (decapoda, macofauna)

Capitella capitata (polychaeta)

Caprellidae sp. indet. (Crsutacea, Amphipoda)

Chaetoderma nitidulum (mollusca)

Chaetognathidae

Chaetozone/Tharyx (polychaeta)

Chaetozone setosa (polychaeta)

Cerianthus lloydi (Cnidaria)

Cirratulidea sp. A (polychaeta)

Cirratulidea sp. B (polychaeta)

Cirratulus cirratus (polychaeta)

Cirratulus filiformis (polychaeta)

Cirriformia tentacula (polychaeta)

Cirrophorus lyra (polychaeta)

Copepoda sp. indet. (copepoda)

Corbula gibba (mollusca)

$\begin{array}{llllllllll} & & 1 & 0.1 & & & & & & \\ 1 & 0.9 & 7 & 1.6 & 1724 & 7.5 & 66 & 38.3 & 81 & 3.6\end{array}$

$\begin{array}{lllll}1 & 0.0 & & \\ & & & 3 & 1.3\end{array}$

Cultellus pellucidus (mollusca)

Cumacea sp. indet. (Crsutacea)

Dasybranchus caducus (polychaeta)

Dyastilis rathkei (Crsutacea)

Diplocirrus glaucus (polychaeta)

Erinacea sp. indet

Eteone longa (polychaeta)

Eteone sp. (polychaeta)

Eulalia viridis (polychaeta)

Eulalia sp. indet (polychaeta)

Eumida punctifera (polychaeta)

Gastropoda sp. indet. (mollusca)

Gattyana cirrosa (polychaeta)

Glycera alba (polychaeta)
$9 \quad 2.1$

10.9

20.5

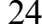

10.9

37

$3 \quad 0.7$

10.9

$\begin{array}{llll} & & 1 & 0.0\end{array}$

$1 \quad 0.1$

$\begin{array}{llll}1 & 0.9 & 17 & 3.8\end{array}$

$\begin{array}{llll}2 & 0.3 & 5 & 0.0\end{array}$

$1 \quad 0.2$

10.9

$\begin{array}{ll}12 & 2.7\end{array}$
Glycera rouxii (polychaeta)

Goniada maculata (polychaeta) $\begin{array}{ll}2 & 0.2 \\ 2 & 0.3\end{array}$

10.2
$4 \quad 0.2$

$\begin{array}{lll}0 & 1 & 0.6\end{array}$

$214 \quad 9.5$

\begin{tabular}{ll}
6 & 2.7 \\
\hline & 0.7
\end{tabular}

20.7

$\begin{array}{ll}1 & 0.8\end{array}$

$6 \quad 5.1$

1

$1 \quad 0.1$

$1 \quad 0.1$

$\begin{array}{llll}7 & 0.8 & 1 & 0.3 \\ 2 & 0.2 & & \\ & & 1 & 0.3\end{array}$

10.1

$\begin{array}{lllll}1.8 & 5 & 0.1 & & \\ 1 & 5 & 2 & 1.3\end{array}$

$\begin{array}{ll}2 & 0.1 \\ 1 & 0.0 \\ 3 & 0.1 \\ 17 & 0.7 \\ 1 & 0.0\end{array}$

\author{
$\begin{array}{lllllll} & 1 & 0.8 & & & 3 & 0.3 \\ 0.9 & 2 & 1.7 & 10 & 1.4 & 1 & 0.1 \\ & 2 & 1.3 & 4 & 0.5 & 31 & 3.3\end{array}$
}

(continued on next page) 
Appendix D (continued)

\begin{tabular}{|c|c|c|c|c|c|c|c|c|c|c|c|c|c|c|c|c|c|c|c|c|}
\hline Distance $(\mathrm{km})$ & 8.0 & & 2.8 & & 1.2 & & 0.0 & & 1.7 & & 2.6 & & 2.9 & & 1.8 & & 1.5 & & 3.2 & \\
\hline Species & G1 & $\%$ & $\mathbf{J} 7$ & $\%$ & M7 & $\%$ & P7 & $\%$ & $\mathrm{~T} 7$ & $\%$ & V7 & $\%$ & $\mathrm{P} 4$ & $\%$ & P5 & $\%$ & P8.5 & $\%$ & $\mathrm{P} 10$ & $\%$ \\
\hline Harmathoe impar (polychaeta) & & & & & & & & & & & & & & & & & & & 1 & 0.3 \\
\hline Harmathoe sp. indet (polychaeta) & & & 1 & 0.2 & & & & & & & & & 1 & 0.4 & 1 & 0.1 & & & & \\
\hline Hemicordata (macrofauna) & & & & & & & & & & & & & & & & & & & 1 & 0.3 \\
\hline Heterocirrus sp. indet. (polychaeta) & & & & & & & & & & & & & & & 3 & 0.4 & & & & \\
\hline Hydroidea (macrofauna) & & & & & & & & & & & 1 & 0.2 & & & & & 1 & 0.1 & & \\
\hline Isopoda sp. indet. (macrofauna) & & & & & & & & & 1 & 0.0 & & & & & & & & & & \\
\hline Kefersteina cirrata (polychaeta) & & & 1 & 0.1 & & & & & & & & & & & & & & & & \\
\hline Lagisca extenuata (polychaeta) & & & & & & & & & & & & & & & 1 & 0.1 & & & & \\
\hline Laonice cirrata (polychaeta) & & & & & 4 & 0.0 & & & & & & & & & 1 & 0.2 & & & & \\
\hline Lepidonotus squamata & & & & & & & & & 1 & 0.0 & & & & & 1 & 0.2 & & & & \\
\hline Leptosynapta inhaerens (Echinodermata) & & & 1 & 0.1 & & & & & & & & & & & & & & & & \\
\hline Litocorsa stremma (Echinodermata) & & & & & & & & & & & & & & & 1 & 0.2 & & & & \\
\hline Lucinoma borealis (mollusca) & & & 1 & 0.1 & & & & & & & & & & & & & & & & \\
\hline Lumbrinereis fragilis (polychaeta) & & & & & & & & & 1 & 0.0 & & & & & & & & & & \\
\hline Lumbrinereis latrielli (polychaeta) & & & & & & & & & 9 & 0.4 & & & & & & & 1 & 0.1 & & \\
\hline Lumbrinereis tetraura (polychaeta) & 2 & 2.6 & 6 & 1.4 & & & & & & & & & 1 & 0.8 & 4 & 0.5 & 29 & 3.1 & 6 & 3.5 \\
\hline Lumbrinereis sp. indet. (polychaeta) & & & & & & & & & & & 3 & 1.3 & & & & & & & & \\
\hline Malacoceros fuliginosa (polychaeta) & & & & & 20 & 0.1 & & & & & & & & & & & & & & \\
\hline Maldanidea $\mathrm{sp}$. Indet & & & & & & & & & & & & & & & & & & & & \\
\hline Mediomastus fragilis (polychaeta) & 2 & 2.6 & 7 & 1.5 & 248 & 1.1 & 1 & 0.6 & 1222 & 54.5 & 28 & 12.4 & 7 & 5.5 & 197 & 29.9 & 346 & 37.1 & 3 & 1.6 \\
\hline Melinna palmata (polychaeta) & & & & & & & & & 117 & 5.2 & 1 & 0.2 & & & 3 & 0.5 & 3 & 0.3 & & \\
\hline Mollusca sp. Indet (macrofauna) & & & & & & & & & & & 1 & 0.2 & & & & & & & & \\
\hline Montacuta ferruginosa (mollusca) & & & & & & & & & 4 & 0.2 & & & & & & & & & 1 & 0.6 \\
\hline Myriochele heeri (polychaeta) & & & 5 & 1.0 & & & & & 1 & 0.0 & 6 & 2.4 & & & & & & & & \\
\hline Mysella bidentata (mollusca) & & & 1 & 0.1 & & & & & & & & & & & 4 & 0.6 & & & & \\
\hline Mystides & & & & & & & & & & & & & & & 1 & 0.2 & & & & \\
\hline Natica sp. (mollusca) & & & & & & & & & 1 & 0.0 & & & & & & & & & & \\
\hline Nematoda (meiofauna) & 1 & 0.9 & 4 & 0.9 & 1044 & 4.6 & 90 & 51.9 & 121 & 5.4 & & & & & & & 85 & 9.1 & & \\
\hline Nemertea T1 (macrofauna) & 1 & 0.9 & 11 & 2.4 & & & 1 & 0.3 & 9 & 0.4 & 2 & 0.7 & 1 & 0.4 & 16 & 2.4 & 7 & 0.8 & & \\
\hline Nemertea $T 2$ (macrofauna) & 1 & 1.7 & 1 & 0.2 & & & & & 9 & 0.4 & & & & & 1 & 0.2 & 14 & 1.4 & 2 & 1.0 \\
\hline Nemertea T3 (macrofauna) & & & 1 & 0.1 & & & & & 1 & 0.0 & 2 & 0.9 & & & 1 & 0.1 & 8 & 0.9 & 1 & 0.3 \\
\hline Nemertea T4 (macrofauna) & & & 1 & 0.1 & & & & & 1 & 0.0 & & & & & & & 1 & 0.1 & & \\
\hline Nephtys hombergii (polychaeta) & & & & & & & & & & & & & & & & & 2 & 0.2 & & \\
\hline Nephtys hystricis (polychaeta) & 2 & 3.5 & 8 & 1.7 & & & & & & & 1 & 0.4 & 4 & 3.0 & 1 & 0.2 & 2 & 0.2 & 8 & 5.1 \\
\hline Nereis punctata (polychaeta) & & & & & & & & & & & & & & & 1 & 0.1 & & & & \\
\hline Nereis sp. indet (polychaeta) & & & & & & & & & 1 & 0.0 & & & & & & & 1 & 0.1 & & \\
\hline Notomastus latericeus (polychaeta) & & & & & & & & & 9 & 0.4 & 1 & 0.2 & & & & & 2 & 0.2 & & \\
\hline
\end{tabular}


Nucula minuta (mollusca)

Nucula tenuis (mollusca)

Nucula turgida (mollusca)

Nucula sulcata (mollusca)

Nuculana minuta (mollusca)

Ophelina acuminata (polychaeta)

Ophiodromus flexuosus (polychaeta)

Ophiotrocha sp. indet. (polychaeta)

Ophiura albida (Echinodermata)

Ophiura sp. indet. (Echinodermata)

Ophiura texturata (Echinodermata)

Owenia fusiformis (polychaeta)

Parvicardium ovale (mollusca)

Parvicardium scabrum (mollusca)

Pectinaria koreni (polychaeta)

Pectinaria auricoma (polychaeta)

Pista cristata (polychaeta)

Philine sp. indet.

Pholoe minuta (polychaeta)

Phoronis sp. indet. (macrofauna)

Phyllodoce sp. indet. (polychaeta)

Platyhelminthes (macrofauna)

Policirrus sp. indet (polychaeta)

Polyphisia crassa (polychaeta)

Polydora sp. Indet. (polychaeta)

Polynoidae sp. indet. (polychaeta)

Praxillella affinis (polychaeta)

Priapulus caudatum (polychaeta)

Prionospio cirrifera (polychaeta)

Prionospio malmgreni (polychaeta)

Prionospio sp. indet. (polychaeta)

Pseudopolydora antennata (polychaeta)

Raricirrus sp. (polychaeta)

Rhodine loveni (polychaeta)

Sabellidae sp. indet. (polychaeta)

Scalibregma inflatum (polychaeta)

Scaphandidaesp.indet. (mollusca)

Scionella lornensis (polychaeta)

Scoloplos armiger (polychaeta)

Scutopus ventralienatus (mollusca)

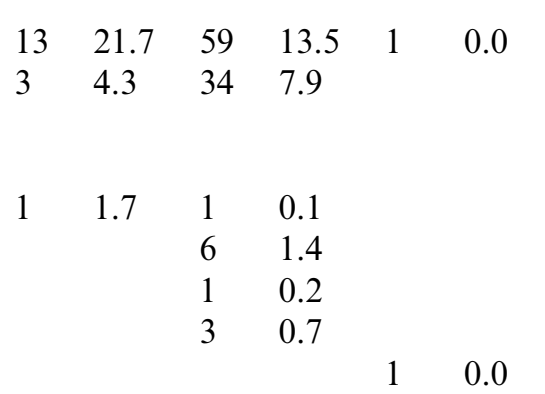

$1 \quad 0.0$

$\begin{array}{llll}2 & 0.1 & 16 & 7.1\end{array}$

$\begin{array}{llllllllllll}4 & 0.2 & 20 & 8.6 & 12 & 10.1 & 13 & 2.0 & 1 & 0.1 & 29 & 18.5\end{array}$

$\begin{array}{lllllllllll}3 & 1 & 0.2 & 4 & 3.4 & 6 & 0.9 & 1 & 0.1 & 14 & 8.6\end{array}$

$\begin{array}{llllllll}2 & 0.1 & 16 & 7.1 & 2 & 1.3 & 1 & 0.2\end{array}$

$\begin{array}{llllllllllll}3 & 0.1 & 1 & 0.4 & 1 & 0.4 & 9 & 1.4 & 1 & 0.1 & 1 & 0.6\end{array}$

$\begin{array}{llllllllll}13 & 0.6 & 18 & 8.0 & 14 & 2.1 & 2 & 0.2 & 2 & 1.3\end{array}$

$2 \quad 0.3$

$7 \quad 1.6$

$1 \quad 0.9 \quad 26 \quad 5.9$

$\begin{array}{ll}1 & 0.1\end{array}$

$3 \quad 0.6$

$\begin{array}{lll}1 & 0.1\end{array}$

$\begin{array}{llll}1 & 0.9 & & \\ & & 1 & 0.1\end{array}$

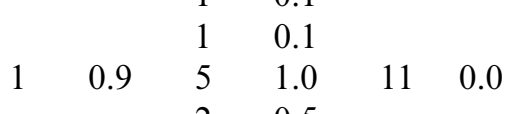

$1 \quad 2.5$

$\begin{array}{llll} & & 2 & 0.3 \\ 1 & 0.9 & 1 & 0.1\end{array}$

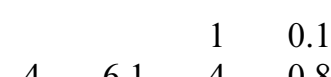

$\begin{array}{llll}4 & 6.1 & 4 & 0.8\end{array}$

10.1

20.3 $\begin{array}{llllll}1 & 0.2 & & 2.1 & 6 & 0.8 \\ & & & 1 & 0.1\end{array}$

$\begin{array}{llllll}3 & 1.1 & 1 & 0.4 & 9 & 1.3\end{array}$

$1 \quad 0.4$

$\begin{array}{llllll}9 & 1.3 & & & 1 & 0.6 \\ & & 1 & 0.1 & 1 & 0.6 \\ 1 & 0.1 & & & 1 & 0.3\end{array}$

$\begin{array}{ll}7 & 0.3\end{array}$

$\begin{array}{llllll} & & 3 & 0.4 & 4 & 0.4 \\ 1 & 0.4 & 4 & 0.5 & 6 & 0.6\end{array}$

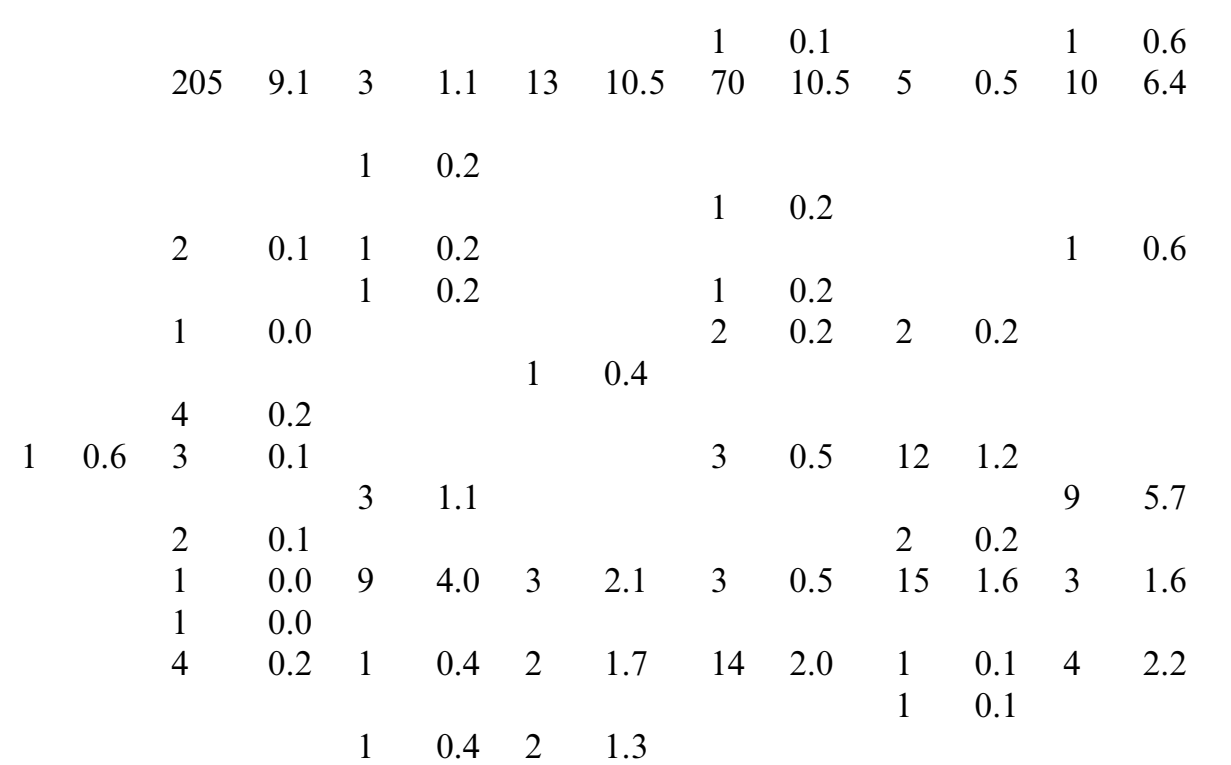

(continued on next page) 
Appendix D (continued)

\begin{tabular}{|c|c|c|c|c|c|c|c|c|c|c|c|c|c|c|c|c|c|c|c|c|}
\hline Distance $(\mathrm{km})$ & 8.0 & & 2.8 & & 1.2 & & 0.0 & & 1.7 & & 2.6 & & 2.9 & & 1.8 & & 1.5 & & 3.2 & \\
\hline Species & G1 & $\%$ & $\mathrm{~J} 7$ & $\%$ & M7 & $\%$ & P7 & $\%$ & $\mathrm{~T} 7$ & $\%$ & V7 & $\%$ & $\mathrm{P} 4$ & $\%$ & P5 & $\%$ & P8.5 & $\%$ & P10 & $\%$ \\
\hline Sphaerodurum gracilis (polychaeta) & & & 1 & 0.1 & & & 1 & 0.6 & & & & & 1 & 0.8 & & & & & & \\
\hline Spionidea (macrofauna) & & & 1 & 0.1 & & & & & & & & & & & & & & & & \\
\hline Spiophanes kroyeri (polychaeta) & 14 & 24.3 & 23 & 5.2 & & & & & 10 & 0.4 & 13 & 5.5 & 6 & 5.1 & 14 & 2.0 & & & 4 & 2.5 \\
\hline Tanaidacea sp. indet. (Isopoda) & & & & & & & & & & & & & & & & & 1 & 0.1 & & \\
\hline Tauberia gracilis (polychaeta) & & & 2 & 0.3 & & & & & & & & & 2 & 1.3 & 3 & 0.4 & & & & \\
\hline Terebellidae sp. indet. (polychaeta) & & & & & & & & & & & & & & & & & 2 & 0.2 & & \\
\hline Terebellides stroemi (polychaeta) & 1 & 1.7 & 2 & 0.5 & & & & & 1 & 0.0 & 2 & 0.7 & 9 & 7.2 & 10 & 1.5 & 1 & 0.1 & 5 & 2.9 \\
\hline Tharyx sp. indet. (polychaeta) & 1 & 1.7 & & & & & & & & & 1 & 0.4 & & & 14 & 2.0 & 1 & 0.1 & 1 & 0.3 \\
\hline Thyasira flexuosa (mollusca) & 1 & 0.9 & 13 & 3.0 & & & & & 47 & 2.1 & 1 & 0.4 & & & 13 & 1.9 & 19 & 2.0 & & \\
\hline Tubificoides benedeni (oligochaeta) & & & 43 & 9.8 & 19808 & 86.4 & 12 & 6.7 & 4 & 0.2 & 1 & 0.2 & & & & & 14 & 1.5 & & \\
\hline Total A (Abundance) & 58 & & 432 & & 22929 & & 173 & & 2241 & & 226 & & 119 & & 660 & & 933 & & 157 & \\
\hline Total S (Species richness) & 30 & & 64 & & 15 & & 10 & & 53 & & 51 & & 37 & & 72 & & 60 & & 38 & \\
\hline Total B (Biomass) & 9.2 & & 45.2 & & 67.2 & & 1.5 & & 30.4 & & 16.8 & & 11.7 & & 38.5 & & 11.9 & & 23.2 & \\
\hline
\end{tabular}


Appendix E. Census data and percentages of foraminiferal fauna $(>150 \mu \mathrm{m})$ in the topmost centimetre of a $0.1 \mathrm{~m}^{2}$ samples

\begin{tabular}{|c|c|c|c|c|c|c|c|c|c|c|c|c|c|c|c|c|c|c|c|c|}
\hline Stations & G1 & & $\mathrm{P} 4$ & & P5 & & $\mathrm{P} 7$ & & $\mathrm{P} 8$ & & $\mathrm{P} 10$ & & $\mathrm{~J} 7$ & & $\mathrm{M} 7$ & & $\mathrm{~T} 7$ & & V7 & \\
\hline Species & A & $\%$ & A & $\%$ & A & $\%$ & A & $\%$ & A & $\%$ & A & $\%$ & A & $\%$ & A & $\%$ & A & $\%$ & A & $\%$ \\
\hline Ammodiscus sp. & & 0.0 & & 0.0 & 1 & 4.8 & & & & 0.0 & & 0.0 & & 0.0 & & 0.0 & 1 & 2.6 & & 0.0 \\
\hline Bulimina marginata & 3 & 5.9 & 5 & 11.6 & 3 & 14.3 & & & 1 & 12.5 & 5 & 5.0 & 1 & 1.2 & 1 & 11.1 & 8 & 21.1 & & 0.0 \\
\hline Discammina compressa & 3 & 5.9 & & 0.0 & & 0.0 & & & & 0.0 & & 0.0 & 1 & 1.2 & 1 & 11.1 & & 0.0 & & 0.0 \\
\hline Eggerrella scabra & 38 & 74.5 & 15 & 34.9 & 2 & 9.5 & & & 6 & 75.0 & 91 & 90.1 & 74 & 91.4 & 6 & 66.7 & 3 & 7.9 & 10 & 90.9 \\
\hline Elphidium crispum & & 0.0 & & 0.0 & 1 & 4.8 & & & & 0.0 & & 0.0 & & 0.0 & & 0.0 & & 0.0 & & 0.0 \\
\hline Elphidium excavatum & & 0.0 & & 0.0 & & 0.0 & & & & 0.0 & 2 & 2.0 & 1 & 1.2 & & 0.0 & & 0.0 & & 0.0 \\
\hline Elphidium sp.1 & & 0.0 & & 0.0 & & 0.0 & & & & 0.0 & 1 & 1.0 & 1 & 1.2 & & 0.0 & & 0.0 & & 0.0 \\
\hline Epistominella vitrea & & 0.0 & & 0.0 & 2 & 9.5 & & & & 0.0 & & 0.0 & & 0.0 & 1 & 11.1 & & 0.0 & & 0.0 \\
\hline Haplophragmoides sp. & & 0.0 & & 0.0 & & 0.0 & & & & 0.0 & & 0.0 & & 0.0 & & 0.0 & & 0.0 & & 0.0 \\
\hline Milionella subrotunda & 1 & 2.0 & & 0.0 & & 0.0 & & & & 0.0 & & 0.0 & & 0.0 & & 0.0 & & 0.0 & & 0.0 \\
\hline Quinqueloculina seminula & & 0.0 & & 0.0 & 2 & 9.5 & & & & 0.0 & 1 & 1.0 & 1 & 1.2 & & 0.0 & 1 & 2.6 & & 0.0 \\
\hline Reophax nodolusus & & 0.0 & 6 & 14.0 & 6 & 28.6 & & & & 0.0 & & 0.0 & & 0.0 & & 0.0 & 20 & 52.6 & 1 & 9.1 \\
\hline Reophax sp1. & 2 & 3.9 & & 0.0 & & 0.0 & & & & 0.0 & & 0.0 & 1 & 1.2 & & 0.0 & & 0.0 & & 0.0 \\
\hline Stainforthia concava & 4 & 7.8 & 16 & 37.2 & & 0.0 & & & & 0.0 & & 0.0 & 1 & 1.2 & & 0.0 & 2 & 5.3 & & 0.0 \\
\hline Textularia porrecta & & 0.0 & & 0.0 & & 0.0 & & & 1 & 12.5 & 1 & 1.0 & & 0.0 & & 0.0 & 3 & 7.9 & & 0.0 \\
\hline Textularia sagittula & & 0.0 & & 0.0 & 1 & 4.8 & & & & 0.0 & & 0.0 & & 0.0 & & 0.0 & & 0.0 & & 0.0 \\
\hline Branched foraminifera & & 0.0 & 1 & 2.3 & 3 & 14.3 & & & & 0.0 & & 0.0 & & 0.0 & & 0.0 & & 0.0 & & 0.0 \\
\hline Total of censed individuals (A) & 51 & & 43 & & 21 & & 0 & & 8 & & 101 & & 81 & & 9 & & 38 & & 11 & \\
\hline Number of species & 6 & & 5 & & 9 & & 0 & & 3 & & 6 & & 8 & & 4 & & 7 & & 2 & \\
\hline
\end{tabular}




\begin{tabular}{|c|c|c|c|c|c|c|c|c|c|c|c|c|c|c|c|c|c|c|c|c|c|c|c|c|c|}
\hline \multirow{2}{*}{$\frac{\text { Stations }}{\text { Species }}$} & \multicolumn{3}{|l|}{ G1 } & \multicolumn{3}{|l|}{$\mathrm{P} 4$} & \multicolumn{3}{|l|}{ P5 } & \multicolumn{2}{|l|}{$\underline{\mathrm{P} 7}$} & \multicolumn{2}{|l|}{$\mathrm{P} 8.5$} & \multicolumn{3}{|l|}{$\mathrm{P} 10$} & \multicolumn{3}{|l|}{$\underline{\mathbf{J} 7}$} & \multicolumn{2}{|l|}{$\mathrm{M} 7$} & \multicolumn{2}{|l|}{$\mathrm{T} 7$} & \multicolumn{2}{|l|}{ V7 } \\
\hline & A & $\mathrm{A} \times \mathrm{s}$ & $\%$ & A & $\mathrm{A} \times \mathrm{s}$ & $\%$ & A & $\mathrm{A} \times \mathrm{s}$ & $\%$ & A & $\%$ & A & $\%$ & A & $\mathrm{A} \times \mathrm{s}$ & $\%$ & A & $\mathrm{A} \times \mathrm{s}$ & $\%$ & A & $\%$ & A & $\%$ & A & $\%$ \\
\hline Ammodiscus sp. & 1 & 4 & 0.6 & 0 & & 0.0 & 1 & 5 & 0.5 & & 0.0 & & 0.0 & 3 & 15 & 1.5 & 0 & & 0.0 & & 0.0 & & 0.0 & & 0.0 \\
\hline Biloculina inflata & 0 & & 0.0 & 0 & & 0.0 & 0 & & 0.0 & & 0.0 & & 0.0 & 0 & & 0.0 & 0 & & 0.0 & & 0.0 & & 0.0 & & 0.0 \\
\hline Biloculinella irregularis & 2 & 7 & 1.0 & 0 & & 0.0 & 3 & 15 & 1.4 & & 0.0 & & 0.0 & 1 & 5 & 0.5 & 0 & & 0.0 & & 0.0 & & 0.0 & & 0.0 \\
\hline Bolivina dilatata & 2 & 7 & 1.0 & 0 & & 0.0 & 2 & 10 & 0.9 & & 0.0 & & 0.0 & 1 & 5 & 0.5 & 1 & 2 & 0.4 & & 0.0 & 4 & 3.1 & & 0.0 \\
\hline Bolivina pygmea & 2 & 7 & 1.0 & 1 & 4 & 0.5 & 0 & & 0.0 & & 0.0 & & 0.0 & 0 & & 0.0 & 1 & 2 & 0.4 & & 0.0 & & 0.0 & & 0.0 \\
\hline Bolivina rostrata & 0 & & 0.0 & 0 & & 0.0 & 0 & & 0.0 & & 0.0 & & 0.0 & 0 & & 0.0 & 0 & & 0.0 & & 0.0 & & 0.0 & & 0.0 \\
\hline Bolivina seminuda & 12 & 43 & 6.0 & 50 & 200 & 24.9 & 49 & 241 & 22.0 & 1 & 50.0 & & 0.0 & 9 & 44 & 4.4 & 38 & 87 & 18.5 & & 0.0 & 39 & 30.2 & 11 & 31.4 \\
\hline Bolivina spathulata & 5 & 18 & 2.5 & 1 & 4 & 0.5 & 4 & 20 & 1.8 & & 0.0 & & 0.0 & 1 & 5 & 0.5 & 1 & 2 & 0.4 & & 0.0 & 1 & 0.8 & 1 & 2.9 \\
\hline Bolivina aenaraiensis & 1 & 4 & 0.6 & 4 & 16 & 2.0 & 0 & & 0.0 & & 0.0 & & 0.0 & 3 & 15 & 1.5 & 5 & 11 & 2.3 & 1 & 11.1 & 2 & 1.6 & & 0.0 \\
\hline Bolivina spp. & 0 & & 0.0 & 4 & 16 & 2.0 & 0 & & 0.0 & & 0.0 & & 0.0 & 0 & & 0.0 & 0 & & 0.0 & & 0.0 & 1 & 0.8 & & 0.0 \\
\hline Bulimina marginata & 8 & 28 & 3.9 & 21 & 84 & 10.5 & 7 & 34 & 3.1 & & 0.0 & 9 & 14.8 & 6 & 30 & 3.0 & 9 & 20 & 4.3 & & 0.0 & 36 & 27.9 & 3 & 8.6 \\
\hline Buliminella elegantissima & 1 & 4 & 0.6 & 0 & & 0.0 & 5 & 25 & 2.3 & & 0.0 & 3 & 4.9 & 1 & 5 & 0.5 & 1 & 2 & 0.4 & & 0.0 & 4 & 3.1 & & 0.0 \\
\hline Cassidulina crassa & 1 & 4 & 0.6 & 3 & 12 & 1.5 & 2 & 10 & 0.9 & & 0.0 & & 0.0 & 0 & & 0.0 & 0 & & 0.0 & & 0.0 & & 0.0 & & 0.0 \\
\hline Cassidulina subglobosa & 0 & & 0.0 & 0 & & 0.0 & 0 & & 0.0 & & 0.0 & & 0.0 & 0 & & 0.0 & 0 & & 0.0 & & 0.0 & & 0.0 & & 0.0 \\
\hline Cyclogera involvens & 0 & & 0.0 & 0 & & 0.0 & 3 & 15 & 1.4 & & 0.0 & & 0.0 & 1 & 5 & 0.5 & 0 & & 0.0 & & 0.0 & 1 & 0.8 & & 0.0 \\
\hline Eggerella advena & 19 & 68 & 9.4 & 5 & 20 & 2.5 & 1 & 5 & 0.5 & & 0.0 & 2 & 3.3 & 17 & 84 & 8.4 & 12 & 27 & 5.7 & & 0.0 & & 0.0 & 10 & 28.6 \\
\hline Eggerella scabra & 28 & 100 & 13.9 & 7 & 28 & 3.5 & 6 & 30 & 2.7 & & 0.0 & 2 & 3.3 & 31 & 153 & 15.2 & 36 & 82 & 17.4 & 3 & 33.3 & 1 & 0.8 & & 0.0 \\
\hline Elphidium albiumbilicatum & 59 & 210 & 29.2 & 27 & 108 & 13.5 & 40 & 197 & 18.0 & & 0.0 & 4 & 6.6 & 25 & 123 & 12.2 & 31 & 71 & 15.1 & 1 & 11.1 & 4 & 3.1 & 2 & 5.7 \\
\hline Elphidium excavatum & 24 & 85 & 11.8 & 11 & 44 & 5.5 & 4 & 20 & 1.8 & & 0.0 & & 0.0 & 19 & 94 & 9.4 & 15 & 34 & 7.2 & & 0.0 & 1 & 0.8 & 3 & 8.6 \\
\hline Epistominella vitrea & 1 & 4 & 0.6 & 14 & 56 & 7.0 & 20 & 98 & 9.0 & & 0.0 & 11 & 18.0 & 9 & 43 & 4.3 & 5 & 11 & 2.3 & 1 & 11.1 & 19 & 14.7 & 1 & 2.9 \\
\hline Haplophragmoides sp. & 0 & & 0.0 & 0 & & 0.0 & 1 & 5 & 0.5 & & 0.0 & & 0.0 & 0 & & 0.0 & 0 & & 0.0 & & 0.0 & & 0.0 & & 0.0 \\
\hline LagenalFissurina sp. & 0 & & 0.0 & 0 & & 0.0 & 0 & & 0.0 & & 0.0 & & 0.0 & 0 & & 0.0 & 2 & 5 & 1.1 & & 0.0 & 2 & 1.6 & & 0.0 \\
\hline Lenticulina sp & 0 & & 0.0 & 0 & & 0.0 & 0 & & 0.0 & & 0.0 & & 0.0 & 0 & & 0.0 & 0 & & 0.0 & & 0.0 & 1 & 0.8 & & 0.0 \\
\hline Milionella subrotunda & 0 & & 0.0 & 0 & & 0.0 & 0 & & 0.0 & & 0.0 & & 0.0 & 0 & & 0.0 & 0 & & 0.0 & & 0.0 & & 0.0 & & 0.0 \\
\hline Nonionella turgida & 21 & 75 & 10.4 & 7 & 28 & 3.5 & 1 & 5 & 0.5 & & 0.0 & & 0.0 & 16 & 79 & 7.9 & 3 & 6 & 1.3 & & 0.0 & & 0.0 & & 0.0 \\
\hline Quinqueloculina seminula & 0 & & 0.0 & 0 & & 0.0 & 0 & & 0.0 & & 0.0 & & 0.0 & 1 & 5 & 0.5 & 1 & 2 & 0.4 & & 0.0 & & 0.0 & & 0.0 \\
\hline Quinqueloculina sp. & 0 & & 0.0 & 2 & 8 & 1.0 & 2 & 10 & 0.9 & & 0.0 & & 0.0 & 0 & & 0.0 & 0 & & 0.0 & & 0.0 & 1 & 0.8 & & 0.0 \\
\hline Reophax nana & 1 & 4 & 0.6 & 15 & 60 & 7.5 & 23 & 113 & 10.3 & & 0.0 & 17 & 27.9 & 34 & 167 & 16.6 & 26 & 59 & 12.6 & 1 & 11.1 & 2 & 1.6 & 4 & 11.4 \\
\hline Reophax nodulosus & 3 & 11 & 1.5 & 1 & 2 & 0.2 & 0 & & 0.0 & & 0.0 & & 0.0 & 2 & 10 & 1.0 & 2 & 5 & 1.1 & & 0.0 & & 0.0 & & 0.0 \\
\hline Reophax scorpius & 0 & & 0.0 & 0 & & 0.0 & 0 & & 0.0 & & 0.0 & & 0.0 & 0 & & 0.0 & 0 & & 0.0 & & 0.0 & & 0.0 & & 0.0 \\
\hline Reophax sp1 & 0 & & 0.0 & 0 & & 0.0 & 0 & & 0.0 & & 0.0 & & 0.0 & 0 & & 0.0 & 0 & & 0.0 & & 0.0 & & 0.0 & & 0.0 \\
\hline Rosalina sp. & 0 & & 0.0 & 0 & & 0.0 & 0 & & 0.0 & & 0.0 & & 0.0 & 0 & & 0.0 & 0 & & 0.0 & & 0.0 & & 0.0 & & 0.0 \\
\hline Saccaminna sp. & 0 & & 0.0 & 0 & 1 & 0.1 & 1 & 3 & 0.3 & & 0.0 & & 0.0 & 0 & & 0.0 & 0 & 1 & 0.2 & & 0.0 & & 0.0 & & 0.0 \\
\hline Sigmolopsis & 0 & & 0.0 & 0 & & 0.0 & 0 & & 0.0 & & 0.0 & & 0.0 & 0 & & 0.0 & 0 & 1 & 0.2 & & 0.0 & & 0.0 & & 0.0 \\
\hline Stainforthia concava & 2 & 7 & 1.0 & 14 & 56 & 7.0 & 29 & 143 & 13.1 & & 0.0 & & 0.0 & 11 & 54 & 5.4 & 4 & 8 & 1.7 & & 0.0 & 4 & 3.1 & & 0.0 \\
\hline Stainforthia sp.1 & 2 & 8 & 1.1 & 3 & 12 & 1.5 & 0 & & 0.0 & & 0.0 & & 0.0 & 0 & & 0.0 & 3 & 6 & 1.3 & & 0.0 & 2 & 1.6 & & 0.0 \\
\hline Textularia agglutinans & 0 & & 0.0 & 1 & 4 & 0.5 & 1 & 5 & 0.5 & & 0.0 & & 0.0 & 0 & & 0.0 & 0 & & 0.0 & & 0.0 & & 0.0 & & 0.0 \\
\hline Textularia porrecta & 3 & 11 & 1.5 & 5 & 20 & 2. & 17 & 84 & 7.7 & 1 & 50.0 & 12 & 19.7 & 13 & 64 & 6.4 & 9 & 21 & 4.5 & 1 & 11.1 & 2 & 1.6 & & 0.0 \\
\hline Textularia sagittula & 0 & & 0.0 & 1 & 4 & 0.5 & 0 & & 0.0 & & 0.0 & 1 & 1.6 & 0 & & 0.0 & 0 & & 0.0 & 1 & 11.1 & 1 & 0.8 & & 0.0 \\
\hline Textularia sp. & 0 & & 0.0 & 0 & & 0.0 & 0 & & 0.0 & & 0.0 & & 0.0 & 0 & & 0.0 & 0 & & 0.0 & & 0.0 & & 0.0 & & 0.0 \\
\hline Trochammina sp. & 0 & & 0.0 & 0 & & 0.0 & 0 & & 0.0 & & 0.0 & & 0.0 & 0 & & 0.0 & 0 & & 0.0 & & 0.0 & & 0.0 & & 0.0 \\
\hline Indeterminated agglutinates & 3 & 11 & 1.5 & 0 & & 0.0 & 0 & & 0.0 & & 0.0 & & 0.0 & 0 & & 0.0 & 2 & 5 & 1.1 & & 0.0 & & 0.0 & & 0.0 \\
\hline Sessil aglutinated & 0 & & 0.0 & 3 & 11 & 1.4 & 0 & & 0.0 & & 0.0 & & 0.0 & 0 & & 0.0 & 0 & & 0.0 & & 0.0 & 1 & 0.8 & & 0.0 \\
\hline Indeterminated species & 0 & & 0.0 & 1 & 4 & 0.5 & 0 & & 0.0 & & 0.0 & & 0.0 & 0 & & 0.0 & 0 & & 0.0 & & 0.0 & & 0.0 & & 0.0 \\
\hline Total of censed individuals (A) & 203 & 720 & & 201 & 802 & & 222 & 1093 & & 2 & & 61 & & 204 & 1005 & & 206 & 470 & & 9 & & 129 & & 35 & \\
\hline Number of species $(\mathrm{S})$ & & 22 & & & 24 & & & 22 & & 2 & & 9 & & & 20 & & & 23 & & 7 & & 21 & & 8 & \\
\hline Split (s) & & 0.28 & & & 0.25 & & & 0.20 & & 1.00 & & 1.00 & & & 0.20 & & & 0.44 & & 1.00 & & 1.00 & & 1.00 & \\
\hline
\end{tabular}




\section{References}

Abel, P.D., 1989. Water Pollution Biology. John Wiley and Sons, Chichester.

Alve, E., 1991a. Benthic foraminifera in sediment cores reflecting heavy metal pollution in Sørf jord, western Norway. Journal of Foraminiferal Research 21, 1-19.

Alve, E., 1991b. Foraminifera, climatic change, and pollution, a study of late Holocene sediments in Drammensfjord, southeast Norway. The Holocene 1, 243-261.

Alve, E., 1995a. Benthic foraminiferal distribution and recolonization of formerly anoxic environments in Drammensfjord, southern Norway. Marine Micropaleontology 25, 169-186.

Alve, E., 1995b. Benthic foraminiferal responses to estuarine pollution, a review. Journal of Foraminiferal Research 25, 190-203.

Alve, E., 1995c. Benthic foraminiferal distribution and recolonisation of formerly anoxic environments in Drammensfjord, southern Norway. Marine Micropaleontology 25, 169-186.

Alve, E., 2000. A case study reconstructing bottom water oxygen conditions in Frierf jord, Norway, over the past five centuries. In: Martin, R.E. (Ed.), Environmental Micropaleontology, The Application of Microfossils to Environmental Geology. Kluwer Academic/ Plenum Publishers, New York, pp. 323-350.

Alve, E., Nagy, J., 1986. Estuarine foraminiferal distribution in Sandebukta, a branch of the Oslo fjord. Journal of Foraminiferal Research $16,261-284$.

Alve, E., Bernhard, J.M., 1995. Vertical migratory response of benthic foraminifera to controlled oxygen concentrations in an experimental mesocosm. Marine Ecology Progress Series 116, 137-151.

Alve, E., Murray, J.W., 1997. High benthic fertility and taphonomy of foraminifera, a case study of the Skagerrak, North Sea. Marine Micropaleontology 31, 157-175.

Alve, E., Murray, J.W., 1999. Marginal marine environments of the Skagerrak and Kattegat, a baseline study of living (stained) benthic foraminiferal ecology. Palaeogeography, Palaeoclimology, Palaeoceanography 146, 171-193.

Armynot du Châtelet, E., Debenay, J.P., Soulard, R., 2004. Foraminiferal proxies for pollution monitoring in moderately polluted harbors. Environmental Pollution 127, 27-40.

Aschan, M.M., Skullerud, A.M., 1990. Effects of changes in sewage pollution on soft-bottom macrofauna communities in the inner Oslofjord, Norway. Sarsia 75, 169-190.

Bachelet, G., Laubier, L., 1994. Morphology, ecology and juvenile development of Cossura pygodactylata Jones (Polychaeta, Cossuridae) in Arcachon Bay, SW France, with a reassessment of the geographical distribution of C. pygodactylata and C. soyeri Laubier. Mémoires du Muséum national d'histoire naturelle (Zool.) 162, 355-369.

Bandy, O.L., Ingle, J.C., Resig, J.M., 1964. Foraminiferal trends, Laguna Beach outfall area, California. Limnology and Oceanography 9, 112123.

Bandy, O.L., Ingle, J.C., Resig, J.M., 1965. Foraminiferal trends, Hyperion outfall area, california. Limnology and Oceanography 10, 314-332.

Barmawidjaja, D.M., 1991. Studies in living and fossil foraminifers from seasonally productive regions. Geologica Ultraiectina 82, 221.

Barmawidjaja, D.M., Jorissen, F.J., Puskaric, S., Van der Zwaan, G.J., 1992. Microhabitat selection by benthic foraminifera in the northern Adriatic Sea. Journal of Foraminiferal Research 22, 297-317.

Barmawidjaja, D.M., Van Der Zwaan, G.J., Jorissen, F.J., Puskaric, S., 1995. 150 years of eutrophication in the northern Adriatic Sea, evidence from a benthic foraminiferal record. Marine Geology 122, 367-384.

Bates, J.M., Spencer, R.S., 1979. Modification of foraminiferal trends by the Chesapeake-Elisabeth sewage outfall, Virginia Beach, Virginia. Journal of Foraminiferal Research 9 (2), 125-140.

Bernhard, J.M., Sen Gupta, B.K., 1999. Foraminifera of oxygen depleted environments. In: Sen Gupta, B.K. (Ed.), Modern Foraminifera. Kluwer, Dorcrecht, pp. 201-216.
Bernhard, J.M., Sen Gupta, B.K., Borne, P.F., 1997. Benthic foraminiferal proxy to estimate dysoxic bottom-water oxygen concentrations, Santa Barbara basin, US Pacific continental margin. Journal of Foraminiferal Research 27, 301-310.

Blackwelder, P., Hood, T., Alvarez-Zarikian, C., Nelsen, T.A., McKee, B., 1996. Benthic foraminifera from the NECOP study area impacted by the Mississippi River plume and seasonal hypoxia. Quaternary International 31, 19-36.

Blake, J.A., 1993. Life history analysis of five dominant infaunal polychaete species from the continental slope off North Carolina. Journal of the Marine Biology Association of the United Kingdom 73, 123-141.

Boltowskoy, E., 1965. Los Foraminiferos Recientes. Editorial Universitaria de Buenos Aires, Argentina, pp. 510.

Boltowskoy, E., Wright, R., 1976. Recent Foraminifera. Dr. W. Junk b.v., The Hague, pp. 515.

Bremmer, J.M., 1983. Biogenic sediments on the southwest African (Namibian) continental margin. In: Thiede, J., Suess, E. (Eds.), Costal Upwelling. Its Sediment Record, Part B. NATO Conferences Series, vol. 4, New York, pp. 423-430.

Buckley, D.E. et al., 1974. Canso strait and Chedaucto bay, a multidisciplinary study of the impact of man on the marine environment. Geological Survey of Canada 1, 30-74.

Cao, Y., Bark, W.A., Williams, W.P., 1997. Analysing benthic macroinvertebrate community changes along a pollution gradient, A framework for the development of biotic indices. Water Research 31, 884 889.

Carvalho, S., Moura, A., Gaspar, M.B., Pereira, P., Cancela da Fonseca, L., Falcão, M., Drago, T., Leitão, F., Regala, J., 2005. Spatial and inter-annual variability of the macrobenthic communities within a coastal lagoon (Óbidos lagoon) and its relationship with environmental parameters. Acta Oecologica 27, 143-159.

Chandler, J.R., 1970. A biological approach to water quality management. Water Pollution Control. London 69, 415-422.

Christensen, A.G., 1970. Feeding biology of the sea-star Astropecten irregularis Pennant. Ophelia, 8, 1e134. Comparisons to Hoglund's 1927 material. Journal of Foraminiferal Research 31, 2-11.

Conlan, K.E., Kim, S.L., Lenihan, H.S., Oliver, J.S., 2004. Benthic changes during 10 years of organic enrichment by McMurdo Station, Antarctica. Marine Pollution Bulletin 49, 43-60.

Craib, J.S., 1965. A sampler for taking short undisturbed cores. Journal du Conseil International de l'Exploration de la Mer 30, 34-39.

Dauvin, J.C., 1984. Dynamique des écosystèmes macrobenthiques des fonds sédimentaires de la baie de Morlaix et leur perturbation par les hydrocarbures de l'Amoco Cadiz. Thèse de doctorat Etat, ès sciences, Université de Paris VI, 456 pp + annexes, 192pp.

Dauvin, J.C., 2000. The Muddy Fine Sand Abra alba \pm Melinna palmata Community of the Bayof Morlaix Twenty Years After the Amoco Cadiz Oil Spill. Marine Pollution Bulletin 40, 528-536.

Dauvin, J.C., Thiébaut, E., Gesteira, J.L.G., Ghertsos, K., Gentil, F., Ropert, M., Sylvand, B., 2004. Spatial structure of a subtidal macrobenthic community in the Bay of Veys (western Bay of Seine, English Channel). Journal of Experimental Marine Biology and Ecology 307, 217-235.

De Rijk, S., Jorissen, F.J., Rohling, E., Troelstra, S.R., 2000. Organic flux control on bathymetric zonation of Mediterranean benthic foraminifera. Marine Micropaleontolgy 40, 151-166.

Debenay, J.P. Beck-Eichler, B., Fernandez-Gonzalez, M., Mathieu, R., Bonetti, C., Duleba, W., 1996. Les foraminifères paraliques des côtes d'Afrique et d'Amérique du Sud, de part et d'autre de l'Atlantique, comparaison et discussion. In: S. Jardiné, I. Klazis, J.-P. Debenay (Eds.), Géologie de l'Arique et de l'Atlantique sud. Compte Rendu des Colloques de géologie d'Angers. Elf-Aquitaine Edition, Pau, Angers, pp. 463-471.

Debenay, J.P., Redois, F., 1997. Distribution of the twenty seven dominant species of shelf benthic foraminifers on the continental shelf, north of Dakar (Senegal). Marine Micropaleontology 29, 237-255. 
Deegan, C.E., Kirby, R., Rae, I., Floyd, R., 1973. The superficial deposits of the Firth of Clyde and its sea lochs. Report of the Institute of Geological sciences No 73/9. Deep-Sea Research 50, 457-494.

Dewarumez, J.M., Quisthoudt, C., Richard, A., 1986. Suivi pluriannuel du peuplement a Abra alba dans la partie méridionale de la Mer du Nord (region de Dunkerque-France). Hydrobiologia 142, 187-197.

Diaz, R.J., Rosenberg, R., 1995. Marine benthic hypoxia, a review of its ecological effects and the behavioural responses of benthic macrofauna. Oceanography and Marine Biology: Annual Review 33, 245-303.

Digby, P.G.N., Kempton, R.A., 1987. Multivariate Analysis of Ecological Communities. Chapman and Hall, London.

DoE/WTD, 1984. Sewage sludge disposal in Liverpool bay. Research into effects 1975 to 1977. Part 2 - appendices. Water Technical division. Department of the environment, London. 194pp.

Donnici, S., Serandrei-Barbero, R., 2002. The benthic foraminiferal communities of the North Adriatic continental shelf. Marine Micropaleontology 44, 93-123.

Dooley, H.D., 1979. Factors influencing water movements in the Firth of Clyde. Estuarine and Coastal Marine science 9, 631-641.

Dubilier, N., Giere, O., Grieshaber, M.K., 1994. Concomitant effects of sulfide and hypoxia on the aerobic metabolism of the marine oligochaete Tubificoides benedii. Journal of Experimental Zoology 269, 287-297.

Dubilier, N., Giere, O., Grieshaber, M.K., 1995. Morphological and ecophysiological adaptations of the marine oligochaete Tubificoides benedii to sulfidic environments. American Zoology 35, 163-173.

Dubilier, N., Windoffer, R., Grieshaber, M.K., Giere, O., 1997. Ultrastructure and anaerobic metabolism of mitochondria in the marine oligochaete Tubificoides benedii, effects of hypoxia and sulfide. Marine Biology 127, 637-645.

Duijnstee, I., 2001. Experimental ecology of foraminifera, towards better quantitative paleoecological reconstructions, Ph.D. thesis, Utrecht University, Utrecht, Nijmegen University.

Duijnstee, I., Ernst, S.R., Van Der Zwaan, G.J., 2003. Effect of anoxia on the vertical migration of benthic foraminifera. Marine Ecology Progress Series 246, 85-94.

Duijnstee, I., De Lugt, I., Vonk Noordegraaf, H., Van Der Zwaan, B., 2004. Temporal variability of foraminiferal densities in the northern Adriatic Sea. Marine Micropaleontology 50, 125-148.

Durrieu, J., Mojtahid, M., Cazes, L., Galgani, F., Jorissen, F., Camps, R., 2006. In: Aged Drilled Cuttings Offshore Gabon, New Methodology for Assesing their Impact, vol. 98414. Society of Petroleum Engineers Inc. SPE, Abu Dhabi, pp. 8.

Ernst, S., Duijnstee, I., Van Der Zwaan, B., 2002. The dynamics of the benthic foraminiferal microhabitat, recovery after experimental disturbance. Marine Micropaleontology 46, 343-361.

Ernst, S., Van Der Zwaan, B., 2004. Effects of experimentally induced raised levels of organic flux and oxygen depletion on a continental slope benthic foraminiferal community. Deep Sea Research 51, 17091739.

Ernst, S., Bours, R., Duijnstee, I., Van Der Zwaan, B., 2005. Experimental effects of an organic matter pulse and oxygen depletion on a benthic foraminiferal shelf community. Journal of Foraminiferal Research 35, 177-197.

Fauchald, K., Jumars, P.A., 1979. The diet of worms, a study of Polychaete feeding guilds. Oceanography and Marine Biology Annual Review 17, 193-284.

Fenchel, T., Finlay, B.J., 1995. Ecology and Evolution in Anoxic Worlds. Oxford university press, Oxford.

Fenske, C., Günther, B., 2001. Electro-fishing in the lab, A new method to detect acute effectsof heavy metals and organic pollutants in invertebrate indicator organisms. International Journal of Hygiene and Environmental Health 204, 157-163.

Fontanier, C., Jorissen, F.J., Chaillou, G., Anschutz, P., Lafon, V., 2003. Seasonal and interannual variability of benthic foraminiferal faunas at $550 \mathrm{~m}$ depth in the Bay of Biscay. Deep Sea Research I 50, 457-494.

Fontanier, C., Jorissen, F.J., Licari, L., Alexandre, A., Anschutz, P., Carbonel, P., 2002. Live benthic foraminiferal faunas from the Bay of
Biscay, faunal density, composition and microhabitats. Deep Sea Research I 49, 751-785.

Giere, O., Rhode, B., Dubilier, N., 1988. Structural peculiarities of the body wall of Tubificoides benedii (Oligochaeta) and possible relations to its life in sulphidic sediments. Zoomorphology 108, 29-39.

Giere, O., Preusse, J.H., Dubilier, N., 1999. Tubificoides benedeni (Tubificidae, Oligochaeta) - a pioneer in hypoxic and sulfidic environments. An overview of adaptive pathways. Hydrobiologia 406, 235-241.

Gooday, A.J., Turley, C.M., 1990. Responses by benthic organisms to inputs of organic material to the ocean floor, a review. Philosophical Transactions of the Royal Society of London A. 331, 119-138.

Gooday, A.J., Bernhard, J.M., Levin, L.A., Suhr, S.B., 2000. Foraminifera in the Arabian Sea oxygen minimum zone and other oxygendeficient settings, taxonomic composition, diversity, and relation to metazoan faunas. Deep Sea Research II 47, 25-54.

Grassle, J.F., Grassle, J.P., 1974. Opportunistic life histories and genetic systems in marine polychaetes. Journal of Marine Research 32 (2), $253-284$.

Gray, J.S., 1981. The Ecology of Marine Sediments. In: An Introduction to the Structure and Function of Benthic Communities. Cambridge University Press, Cambridge, pp. 185.

Gustafsson, M., Nordberg, K., 1999. Benthic foraminifera and their response to hydrography, periodic hypoxic conditions and primary production in the Koljö Fjord on the Swedish west coast. Journal of Sea Research 41, 163-178.

Gustafsson, M., Nordberg, K., 2001. Living (stained) benthic foraminiferal response to primary production and hydrography in the deepest part of the Gullmar Fjord, Swedish West Coast, with comparisons to Höglud's 1927 material. Journal of Sea Research 31, 2-11.

Hayek, L.A.C., Buzas, M.A., 1997. Surveying Natural Populations. New York: Columbia.

Hayward, W.B., Grenfella, H.R., Sabaaa, A.T., Cartera, R., Cochran, U., Lipps, J.H., Shaned, P.R., Morleya, M.S., 2006. Micropaleontological evidence of large earthquakes in the past 7200 years in southern Hawke's Bay, New Zealand. Quaternary Science Review 25, 11861207.

Heinz, P., Hemleben, C., Kitazato, J., 2002. Time-response of cultured deep-sea benthic foraminifera to different algal diets. Deep Sea Research I 849, 517-537.

Heinz, P., Schmiedl, G., Kitazato, H., Hemleben, C., 2001. Response of deep-sea benthic foraminifera from the Mediterenean Sea to simulated phytoplankton pulses under laboratory conditions. Journal of Foraminiferal Research 31 (3), 210-227.

Heip, C., Willems, K.A., Goossens, A., 1977. Vertical distribution of meiofauna and the efficiency of the Van Veen grab on sandy bottoms in lake Grevelingen (the Netherlands). Aquatic ecology 11, 35-45.

Hellawell, J.M., 1986. Biological Indicators of Freshwater Pollution and Environmental Management. Applied Science Publishers., London.

Hill, M.O., Gauch, H.G., 1980. Detrented correspondence analysis, an improved ordination technique. Vegetation 49, 47-58.

Jannik, N.T., Zachariasse, W.J., Van der Zwaan, G.J., 1998. Living (Rose Bengal stained) benthic foraminifera from the Pakistan continental margin (northern Arabian Sea). Deep-Sea Research I 45, 1483-1513.

Jones, R.W., 1994. The Challenger Foraminifera. Oxford University Press.

Jorissen, F.J., 1987. The distribution of benthic foraminifera in the Adriatic Sea. Marine Micropaleontogy 12, 21-48.

Jorissen, F.J., Barmawidjaja, D.M., Puskaric, S., van der Zwaan, G.J., 1992. Vertical distribution of benthic foraminifera in the northern Adriatic Sea, The relation with the organic flux. Marine Micropaleontology 19, 131-146.

Jorissen, F.J., Wittling, I., Peypouquet, J.P., Rabouille, C., Relexans, J.C., 1998. Live benthic foraminiferal faunas off Cape Blanc, NW Africa; community structure and microhabitats. Deep-Sea Research I 45, 2157-2188.

Josefson, A.B., 1990. Increase of benthic biomass in the SkagerrakKattegat during the 1970s and 1980s - effects of organic enrichment. Marine Ecology Progress Series 66, 117-130. 
Kikuchi, T., 1979. Some aspects of ecology, life cycle and taxonomy of the polychaete Capitella capitata, so called pollution indicator. A Review of Benthos Research 17/18, 33-51.

Kramer, S., Botterweg, N., 1991. Aquatic biological early warning systems, an overview. In: Jeffrey, D.W., Madden, B. (Eds.), Bioindicators and Environmental Management. Academic Press, London, pp. 95-126.

Langezaal, A.M., Jorissen, F.J., Brauna, B., Chailloud, G., Fontanier, C., Anschutz, P., van der Zwaan, G.J., 2006. The influence of seasonal processes on geochemical profiles and foraminiferal assemblages on the outer shelf of the Bay of Biscay. Continental Shelf Research 26, $1730-1755$.

Le Cadre, V., Debeney, J.P., Lesourd, M., 2003. Low pH effects on Ammonia Beccarii test deformation: implications for using test deformations as a pollution indicator. Journal of Foraminiferal Research 33, 1-9.

Lenihan, H.S., Peterson, C.H., Kim, S.L., Conlan, K.E., Fairey, R., McDonald, C., Grabowski, J.H., Oliver, J.S., 2003. Variation in marine benthic community composition allows discrimination of multiple stressors. Marine Ecology Progress Series 261, 63-73.

Levin, L.A., Ziebis, W., Mendoza, G.F., Growney-Cannon, V., Walther, S., 2006. Recruitment response of methane-seep macrofauna to sulfiderich sediments, An in situ experiment. Journal of Experimental Marine Biology and Ecology 330, 132-150.

Li, Q., James, N.P., Bone, Y., McGowran, B., 1999. Palaeoceanographic significance of recent foraminiferal biofacies on the southern shelf of Western Australia, a preliminary study. Palaeogeography, Palaeoclimatology, Palaeoecology 147, 101-120.

Loeblich, A.R., Tappan, H., 1964. In: Foraminiferal Genera and Their Classification, vol. 2. Van Nostrand Reinhold $\mathrm{C}^{\circ}$, New York, pp. $970+847$.

Lutze, G.F., Colbourn, W.T., 1984. Recent benthic foraminifera from the continental margin of Northwest Africa, community structure and distribution. Marine Micropaleontology 8, 361-401.

Mackay, D.W., Halcrow, W., Thornton, I., 1972. Sludge dumping in the Firth of Clyde. Marine Pollution Bulletin 3, 7-11.

Mason, C.F., 1991. Biology of Freshwater Pollution, second ed. Longman Scientific and Technical, Essex, pp. 351.

Maurer, D., Gerlinger, T., Nguyen, H., 1998. The response of two spionid polychaetes to natural processes and anthropogenic activities on the San Pedro Shelf, California. Ophelia 48, 185-206.

Matthews, J.B.L., Buchholz, F., Saborowski, R., Tarling, G.A., Dallot, S., Labat, J.P., 1999. On the physical oceanography of the Kattegat and Clyde Sea area, 1996-98, as background to ecophysiological studies on the planktonic crustacean, Meganyctiphanes norvegica (Euphausiacea). Helgoland Marine Research 53, 70-84.

McCall, P.L., 1977. Community patterns and adaptative strategies of the infaunal benthos of Long Island Sound. Journal of Marine Research 35, 221-265.

McIntyre, A.D., 1977. Effects of pollution on inshore benthos. In: Coull, B.C. (Ed.), Ecology of Marine Benthos. University of South Carolina Press, Columbia, pp. 301-318.

Mendes, I., Gonzalez, R., Dias, J.M.A., Lobo, F., Martins, V., 2004. Factors influencing recent benthic foraminifera distribution on the Guadiana shelf (Southwestern Iberia). Marine Micropaleontology 51, 171-192.

Mendez, N., Romero, J., Flos, J., 1997. Population dynamics and production of the polychaetes Capitella capitata in the littoral zone of Barcelona (Spain, NW Mediterranean). Journal of Experimental Marine Biology and Ecology 218 (2), 263-284.

Modig, H., Ólafsson, E., 1998. Responses of Baltic benthic invertebrates to hypoxic events. Journal of Experimental Marine Biology and Ecology 229, 133-148.

Moodley, L., Van Der Zwaan, G.J., Herman, P.M.J., Kempers, L., Van Breugel, P., 1997. Differential response of benthic meiofauna to anoxia with special reference to Foraminifera (Protista, Sarcodina). Marine Ecology Progress Series 158, 151-163.
Mojtahid, M., Jorissen, F., Durrieu, J., Galgani, F., Howa, H., Redois, F., Camps, R., 2006. Benthic foraminifera as bio-indicators of drill cutting disposal in tropical east Atlantic outer shelf environments. Marine Micropaleontology 61, 58-75.

Morvan, J., Le Cadre, V., Jorissen, F., Debenay, J.P., 2004. Foraminifera as potential bio-indicators of the "Erika" oil spill in the Bay of Bourneuf, Field and experimental studies. Aquatic Living Research 17, 317-322.

Morvan, J., Debenay, J.P., Jorissen, F., Redois, F., Bénéteau, E., Delplancke, M., Ama, A.-S., 2006. Patchiness and life cycle of intertidal foraminifera, Implication for environmental and paleoenvironmental interpretation. Marine Micropaleontology 61, 131-154.

Murray, J.W., 1991. Ecology and Palaeoecology of Benthic Foraminifera. Longman Scientific \& Technical, Harlow, pp. 397.

Murray, J.W., 1995. Microfossil indicators of ocean water masses, circulation and climate. In: Bosence, D.W.J., Allison, P.A. (Eds.), . In: Marine Palaeoenvironmental Analysis from Fossils, vol. 83. Geological Society Special Publication, pp. 245-264.

Murray, J.W., 2006. Ecology and Applications of Benthic Foraminifera. Cambridge University Press, Cambridge, pp. 426.

Nagy, J., Alve, E., 1987. Temporal changes in foraminiferal faunas and impact of pollution in Sandebukta, Oslo fjord. Marine Micropaleontology $12,109-128$.

Nagy, J., Johansen, H.O., 1991. Delta-influenced foraminiferal assemblages from the Jurassic (Toarcian-Bajocian) of the northern North Sea. Micropaleontology 37, 1-40.

Neal, K.J., Ballerstedt, S., 2006. Cirratulus cirratus. A bristleworm. Marine Life Information Network, Biology and Sensitivity Key Information Sub-programme [on-line]. Plymouth, Marine Biological Association of the United Kingdom. <http,//www.marlin.ac.uk/ species/Cirratuluscirratus.htm $>$.

Neira, C., Sellanes, J., Levin, L.A., Arntz, W.A., 2001. Meiofaunal distributions on the Peru margin: relationship to oxygen and organic matter availability. Deep-Sea Research 48, 2453-2472.

Niermann, U., Bauerfeind, E., Hickel, W., Westernhagen, H.V., 1990. The recovery of benthos following the impact of low oxygen content in the German Bight. Netherlands Jour.of Sea Res. 25, 215-226, Nijmegen, The Netherlands, 149pp.

Nilsson, H.C., 1999. Effects of hypoxia and organic enrichment on growth of the brittle stars Amphiura filiformis (O.F. Müller) and Amphiura chiajei Forbes. Journal of Experimental Marine Biology and Ecology 237, 11-30

Nilsson, H.C., Rosenberg, R., 1994. Hypoxic response of two marine benthic communities. Marine Ecology Progress Series 115, 209-217.

Nilsson, H.C., Sköld, M., 1996. Arm regeneration and spawning in the brittle star Amphiura filiformis (O.F. Müller) during hypoxia. Journal of Experimental Marine Biology and Ecology 199, 193-206.

Pearson, T.H., Rosenberg, R., 1978. Macrobenthic succession in relation to organic enrichment and pollution of the marine environment. Oceanography and Marine Biology Annual Review 16, 229-311.

Pearson, T.H., Gray, J., Johannessen, P.J., 1983. Objective selection of sensitive species indicative of pollution-induced change in benthic communities. 2. Data analyses. Marine Ecology Progress Series 12, 237-255.

Pearson, T.H., 1985. The benthic ecology of an accumulating sludge disposal ground. In: Proceedings of the Fourth International Ocean Disposal Symposium, Plymouth, England, April, 1983.

Pearson, T.H., 1986. Disposal of sewage in dispersive and non-dispersive areas, contrasting cas histories in British coastal waters. In: G. Kullenberg (Ed.), The Role of the Oceans as a Waste Disposal Option, pp. 577-595.

Pearson, T.H., Duncan, G., Nuttal, J., 1986. Long term changes in benthic communities of Loch Linnhe and Loch Eil (Scotland). Hydrobiologia 142, 113-119.

Pearson, T.H., 1988. Survey report. Garroch Head sludge disposal ground survey.

Penry, D.L., Jumars, P.A., 1990. Gut architecture, digestive constraints and feeding ecology of deposit-feeding and carnivorous polychaetes. Oecologia 82, 1-11. 
Perés, J.M., Picard, J., 1964. Nouveau manuel de bionomie benthique de la Méditerranée. Bulletin Travaux Station Marine d'Endoume 31, 5137.

Phleger, F.B., Parker, F.L., Peirson, J.F., 1953. North Atlantic Foraminifera. Reports of the Swedish Deep-Sea Expedition 7 (1), 1-122.

Phleger, F.B., Soutar, A., 1973. Production of benthic foraminifera in the tree east Pacific minima. Micropaleontology 19, 110-115.

Platon, E., Sen Gupta, B.K., Rabalaisc, N.N., Turner, R.E., 2005. Effect of seasonal hypoxia on the benthic foraminiferal community of the Louisiana inner continental shelf, The 20th century record. Marine Micropaleontology 54, 263-283.

Reaves, C.M., 1986. Organic matter metabolizability and calcium carbonate dissolution in nearshore marine muds. Journal of Sedimentary Petrology 56, 486-494.

Resig, J.M., 1960. Foraminiferal ecology around ocean outfalls off southern California. In: Person, E. (Ed.), Disposal in the Marine Environment. Pergamon Press, London, pp. 104-121.

Risgaard-Petersen, N., Langezaal, A.M., Ingvardsen, S., Schmid, M.C., Jetten, M.S.M., Op den Camp, H.J.M., Derksen, J.W.M., Piña-Ochoa, E., Eriksson, S.P., Nielsen, L.P., Peter Revsbech, N., Cedhagen, T., van der Zwaan, G.J., 2006. Evidence for complete denitrification in a benthic foraminifer. Nature 443, 93-96.

Rosenberg, R., 1976. Benthic faunal dynamics during succession following pollution abatement in a Swedish estuary. Oikos 27, 414 427.

Rosenberg, R., Loo, L.O., 1988. Marine eutrophication induced oxygen deficiency, effects on soft bottom fauna, western Sweden. Ophelia 29, 213-225.

Rosenberg, R., Hellman, B., Johansson, B., 1991. Hypoxic tolerance of marine benthic fauna. Marine Ecology Progress Series 79, 127-131.

Rosenberg, D.M., Resh, V.H., 1993. Freshwater Biomonitoring and Benthic Macro-invertebrates. Chapman and Hall, London.

Salen-Picard, C., Arlhac, D., Alliot, E., 2003. Responses of a Mediterranean soft bottom community to short-term (1993-1996) hydrological changes in the Rhone River. Marine Environmental Research 55, 409427.

Sanvicente-Anorve, L., Leprêtre, A., Davoult, D., 2002. Diversity of benthic macrofauna in the eastern English Channel, comparison among and within communities. Biodiversity and Conservation 11, 265-282.

Shafer, C.T., 1970. Studies of benthonic foraminifera in the Restigouche estuary: Faunal distributional patterns near pollution sources. Maritime sediments $6,121-134$.

Schafer, C.T., 1973. Distribution of foraminifera near pollution sources in Chaleur Bay. Water, Air, and Soil pollution 2, 219-233.

Schafer, C.T., Wagner, F.J.E., Ferguson, C., 1975. Occurence of foraminifera, molluscs and ostracods adjacent to the industrialized shoreline of Canso Strait, Nova Scotia. Water, Air and Soil Pollution 5, 79-96.

Shannon, C.E., 1948. A mathematical theory of communication. Bell System Technical Journal 27 (379-423), 623-656.

Sharifi, A.R., Croudace, I.W., Austin, R.L., 1991. Benthic foraminiferids as pollution indicators in Southampton Water, southern England, UK. Journal of Micropaleontology 10 (1), 109-113.

Simonini, R., Ansaloni, I., Bonvicini Pagliai, A.M., Prevedelli, D., 2004. Organic enrichment and structure of the macrozoobenthic community in the northern Adriatic Sea in an area facing Adige and Po mouths. ICES Journal of Marine Science 61, 871-881.

Somero, G.N., Childress, J.J., Anderson, A.E., 1989. Transport, metabolism, and detoxification of hydrogen sulfide in animals from sulfiderich marine environments. Review of Aquatic Science 1, 591-614.
Steyaert, M., Moodley, L., Nadong, T., Moens, T., Soetaert, K., Vincx, M., 2007. Responses of intertidal nematodes to short-term anoxic events. Journal of Experimental Marine Biology and Ecology 345, $175-184$.

Sutherland, T.F., Levings, C.D., Petersen, S.A., Poon, P., Piercey, B., 2007. The use of meiofauna as an indicator of benthic organic enrichment associated with salmonid aquaculture. Marine Pollution Bulletin 54, 1249-1261.

Szarek, R., Kuhnt, W., Kawamura, H., Kitazato, H., 2006. Distribution of recent benthic foraminifera on the Sunda Shelf (South China Sea). Marine Micropaleontology 61, 171-195.

Szymelfenig, M., Kotwicki, L., Graca, B., 2006. Benthic re-colonization in post-dredging pits in the Puck Bay (Southern Baltic Sea). Estuarine Coastal and Shelf Science 68, 489-498.

Thomas, E., Gapotchenko, T., Varekamp, J.C., Mecray, E.L., Buchholz ten Brink, M.R., 2000. Benthic foraminifera and environmental changes in Long Island Sound. Journal of Coastal Research 16, 641655.

Tsujimoto, A., Nomura, R., Yasuhara, M., Yamazaki, H., Yoshikawa, S., 2006. Impact of eutrophication on shallow marine benthic foraminifers over the last 150 years in Osaka Bay, Japan. Marine Micropaleontology $60,258-268$.

Tsutsumi, H., Kikuchi, T., 1984. Study of the life history of Capitella capitata (Polychaeta, Capitellidae) in Amakusa, South Japan including a comparison with other geographical regions. Marine Biology 80, 315-321.

Tsutsumi, H., 1990. Population persistence of Capitella sp. (Polychaeta; Capitellidae) on a mud flat subject to environmental disturbance by organic enrichment. Marine Ecology Progress Series 63, 147-156.

Tyson, R.V., Pearson, T.H., 1991. Modern and Ancient Continental Shelf Anoxia. Geological Society of London Special Publication, pp. 474.

Van der Zwaan, G.J., Jorissen, F., 1991. Biofacial patterns in riverinduced shelf anoxia. In: Tyson, R.V., Pearson, T.H. (Eds.), Modern and Ancient Continental Shelf Anoxia, vol. 58. Geological Society, Special Publication, pp. 65-82.

Van Hoey, G., Vincx, M., Degraer, S., 2005. Small-to-large-scale geographical patterns within the macrobenthic Abra alba community. Estuarine, Coastal and Shelf Science 64, 751-763.

Vistisen, B., Vismann, B., 1997. Tolerance to low oxygen and sulfide in Amphiura filiformis and Ophiura albida (Echinodermata, Ophiuroidea). Marine Biology 128, 241-246.

Ward, B.L., Barett, P.J., Vella, P., 1987. Distribution and ecology of benthic foraminifera in McMurdo Sound, Antarctica. Paleogeography, Palaeoclimatology, Paleoecology 58, 139-153.

Warren, L.M., 1976. A population study of the polychaete Capitella capitata in Plymouth. Marine Biology 38, 209-216.

Washington, H.G., 1984. Diversity, biotic and similarity indices, a review with special relevance to aquatic ecosystems. Water Research 18, 653 694.

Watkins, J.G., 1961. Foraminiferal ecology around the Orange County, California, ocean sewer outfall. Micropaleontology 7 (2), 199-206.

Webster, L., Campbell, L.A., 2002. Chlorobiphenyl contaminants at Pladda and Garroch Head in the Firth of Clyde following the cessation of sewage sludge dumping. Journal of Environmental Monitoring 4, 284-290.

Yanko, V., Flexer, A., 1991. Foraminiferal benthonic assemblages as indicators of pollution (an example of north- western shelf of the Black Sea). Third Annual Symp. on the Mediterranean Margin of Israel. Haifa-Israel, pp. 5. 